\title{
Hydrogeology of, and Quality and Recharge Ages of Ground Water in, Prince William County, Virginia, 1990-91
}

By D.L. Nelms and A.R. Brockman

U.S. GEOLOGICAL SURVEY

Water-Resources Investigations Report 97-4009

Prepared in cooperation with the

PRINCE WILLIAM HEALTH DISTRICT 


\title{
U.S. DEPARTMENT OF THE INTERIOR BRUCE BABBITT, Secretary
}

\author{
U.S. GEOLOGICAL SURVEY \\ Gordon P. Eaton, Director
}

For additional information write to:

District Chief

U.S. Geological Survey

3600 West Broad Street, Room 606

Richmond, VA 23230-4916
Copies of this report can be purchased from:

U.S. Geological Survey

Information Services

Box 25286

Denver, CO 80225-0046 


\section{CONTENTS}

Abstract

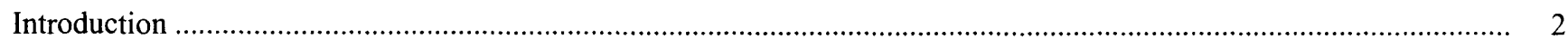

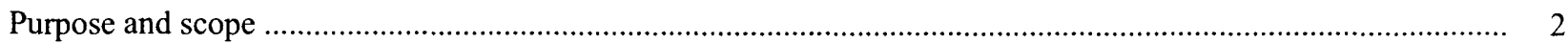

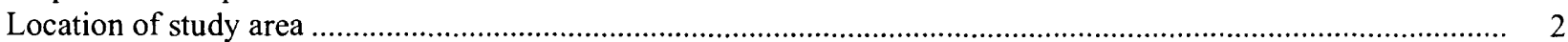

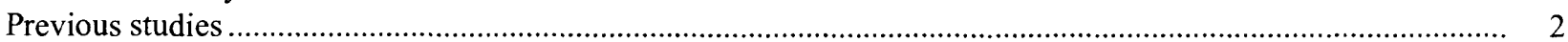

Study methods

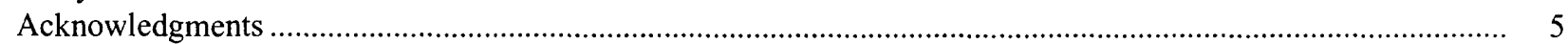

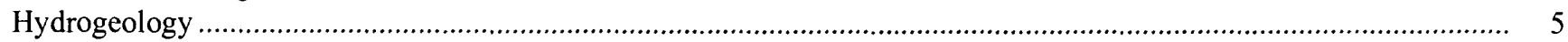

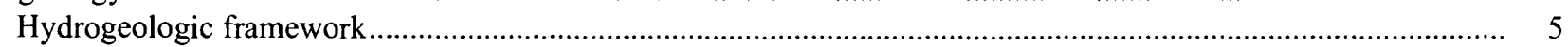

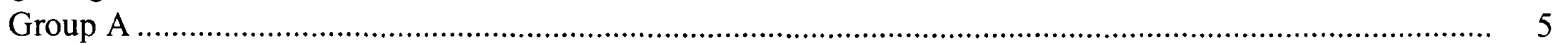

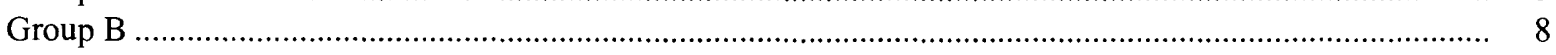

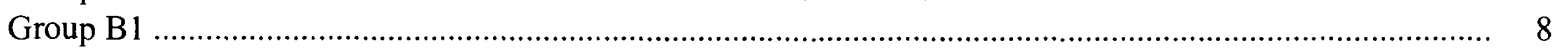

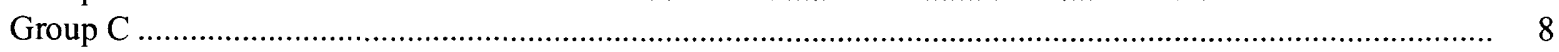

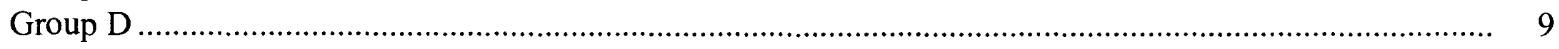

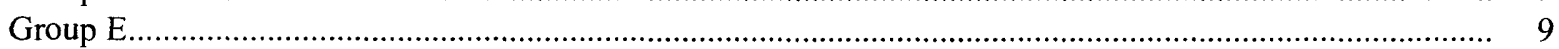

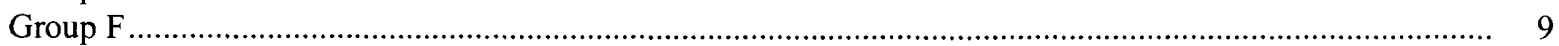

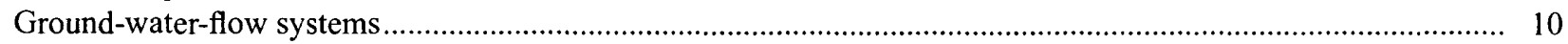

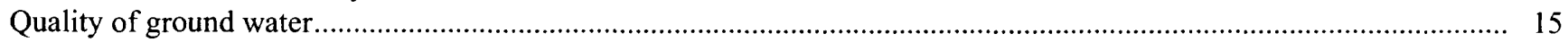

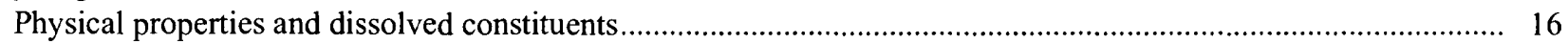

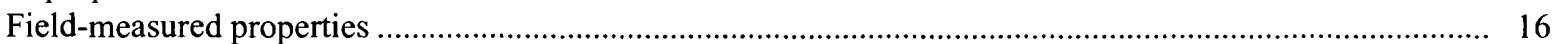

$\mathrm{pH}$

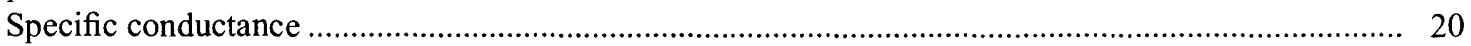

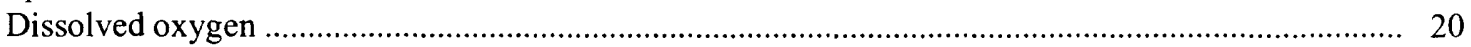

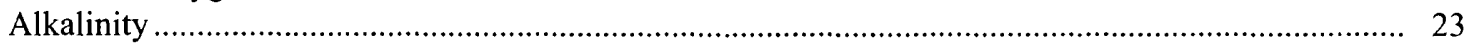

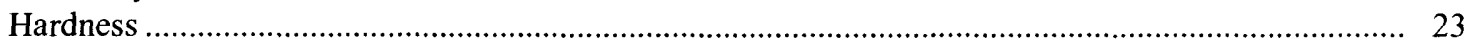

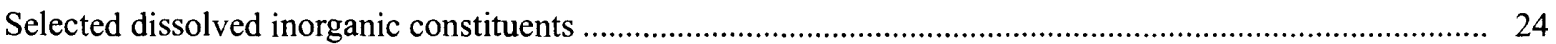

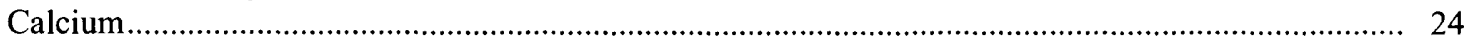

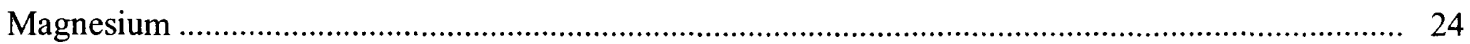

Sodium

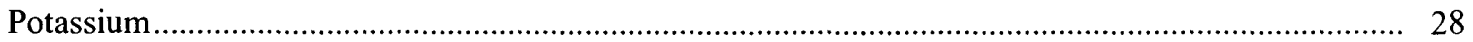

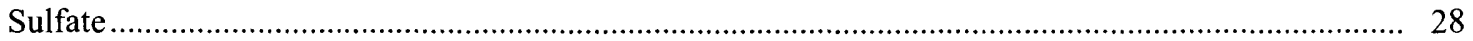

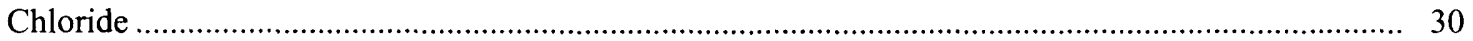

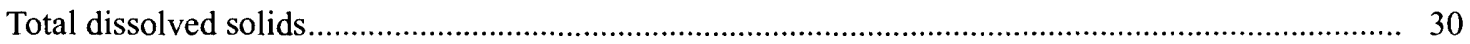

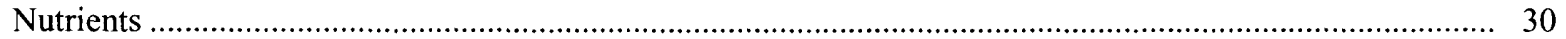

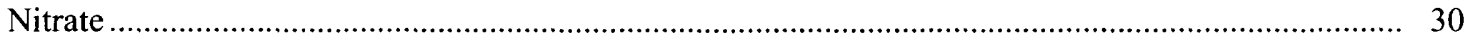

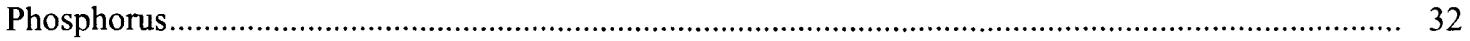

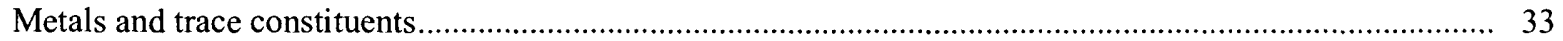

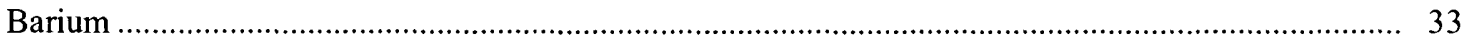

Iron

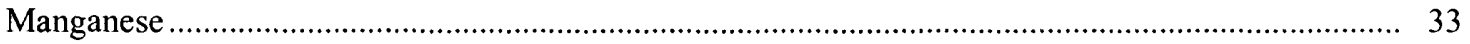

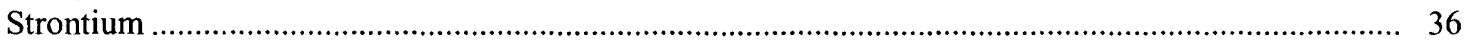

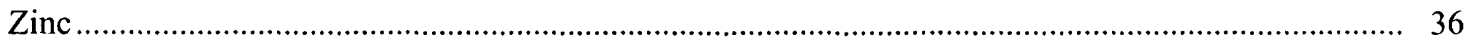

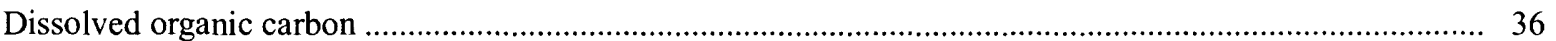

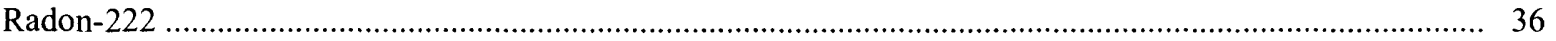

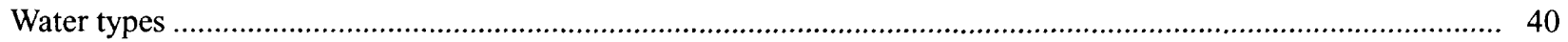

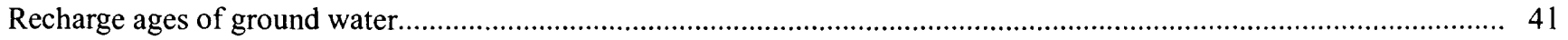

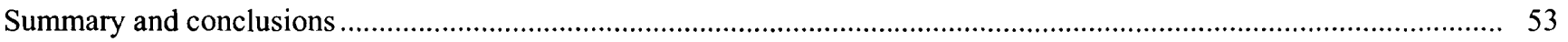

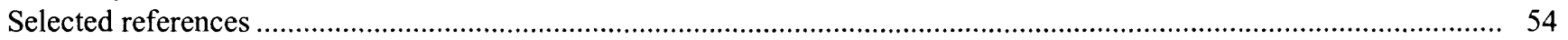




\section{FIGURES}

1,2. Maps showing:

1. Location of study area and geologic provinces in Prince William County, Virginia ................................. 3

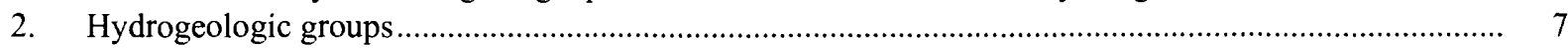

3. Diagram showing conceptualization of the ground-water-flow systems .................................................. 10

4, 5. Maps showing:

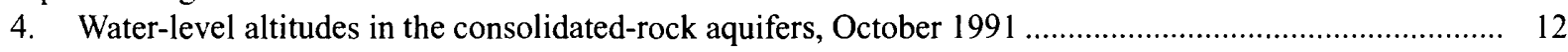

5. Approximate thickness of overburden ....................................................................................... 13

6. Graphs showing declining well yield and water levels in well 51U97H from 1955 to 1977 in

Manassas Park, Virginia ......

7. Map showing location of wells sampled in 1990 and 1991.

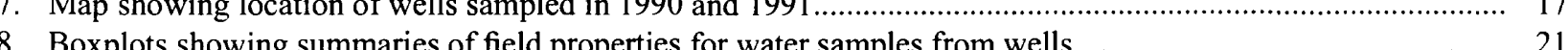

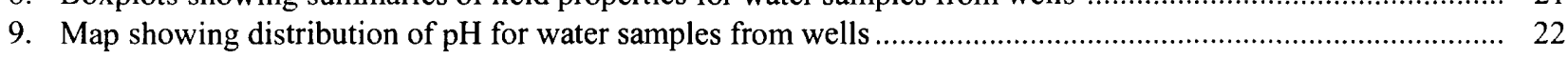

10. Graph showing relation of specific conductance to chloride, hardness, sulfate, and total dissolved solids concentrations

11. Boxplots showing summaries of analyses of hardness and selected inorganic constituents ........................... 25

12-14. Maps showing:

12. Modified Stiff diagrams illustrating ground-water quality ........................................................ 27

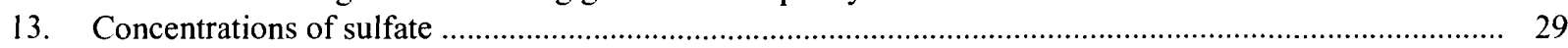

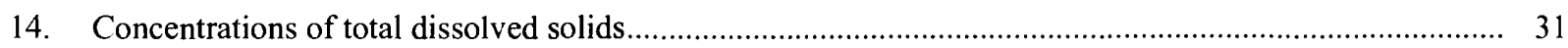

15, 16. Boxplots showing:

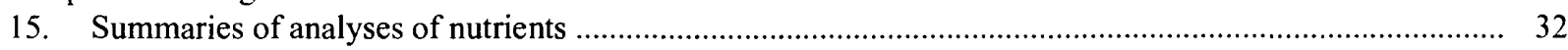

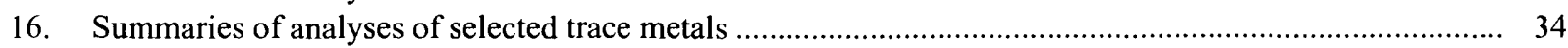

17, 18. Maps showing:

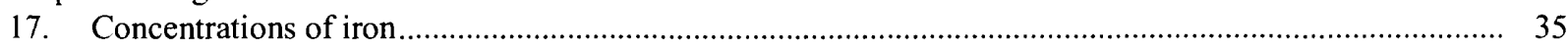

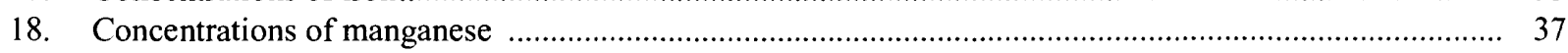

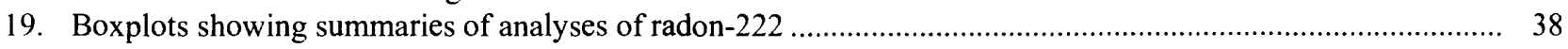

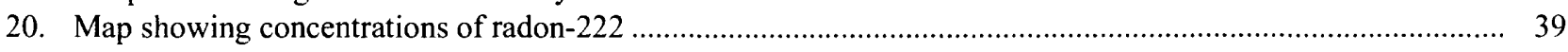

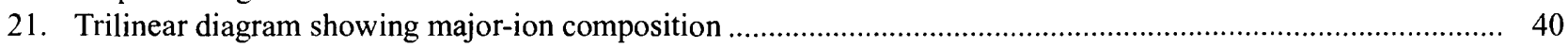

22-24. Graphs showing:

22. Concentrations of chlorofluorocarbon- 11 and chlorofluorocarbon- 12 in the atmosphere ....................... 42

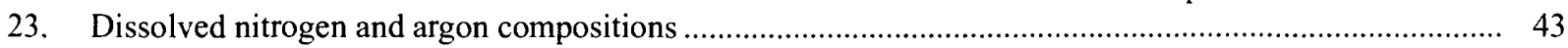

24. Isotopic composition of deuterium and oxygen-18

25-27. Maps showing:

25. Distribution of chlorofluorocarbon-11 model recharge ages ........................................................ 49

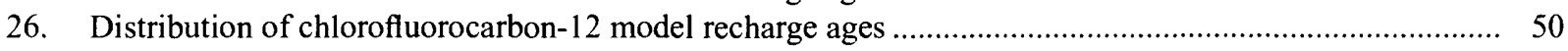

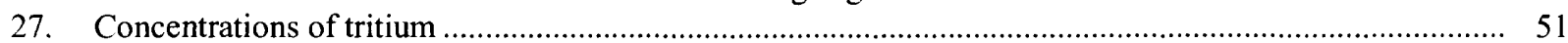

\section{TABLES}

1. Hydrogeologic group classification.....

2. Summary statistics for well yields by hydrogeologic group and water use .....

3. Average composition of precipitation from the National Atmospheric Deposition Program/

National Trends Network (NADP/NTN) station VA28 located in Shenandoah

National Park at Big Meadows, Virginia, 1981-92......

4. Summary statistics for analyses of ground-water samples, 1990-91

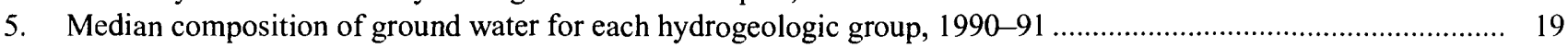

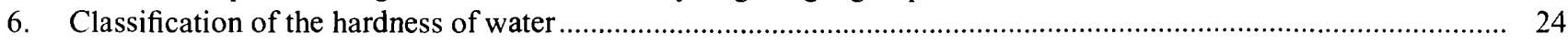

7. Concentrations of dissolved chlorofluorocarbon-11 and chlorofluorocarbon-12 and recharge dates of ground water.

8. Comparison of ground-water-quality analyses, isotopic composition, and recharge ages

for well 49V53 in the Bull Run Mountain area, northwestern Prince William County, Virginia 


\section{CONVERSION FACTORS, VERTICAL DATUM, AND ABBREVIATED WATER-QUALITY UNITS}

\begin{tabular}{|c|c|c|}
\hline Multiply & By & To obtain \\
\hline \multicolumn{3}{|c|}{ Length } \\
\hline \multirow{3}{*}{ mile (mi) } & 0.3048 & meter \\
\hline & 1.609 & kilometer \\
\hline & Area & \\
\hline \multirow[t]{2}{*}{ square mile $\left(\mathrm{mi}^{2}\right)$} & 2.590 & square kilometer \\
\hline & Flow & \\
\hline gallon per minute (gal/min) & 0.06308 & liter per second \\
\hline million gallons per day (Mgal/d) & 0.04381 & cubic meter per second \\
\hline
\end{tabular}

Vertical datum: In this report, "sea level" refers to the National Geodetic Vertical Datum of 1929 - geodetic datum derived from a general adjustment of the first-order level nets of the United States and Canada, formerly called Sea Level Datum of 1929.

Abbreviated water-quality units: Chemical concentrations and water temperature are given in metric units. Chemical concentration is given in milligrams per liter $(\mathrm{mg} / \mathrm{L})$ or micrograms per liter $(\mu \mathrm{g} / \mathrm{L})$. Specific electrical conductance of water is expressed in microsiemens per centimeter at 25 degrees Celsius $(\mu \mathrm{S} / \mathrm{cm})$. Radon-222 $\left({ }^{222} \mathrm{Rn}\right)$ concentration is expressed in picocuries per liter $(\mathrm{pCi} / \mathrm{L})$. Water temperature given in degrees Celsius $\left({ }^{\circ} \mathrm{C}\right)$ can be converted to degrees Fahrenheit $\left({ }^{\circ} \mathrm{F}\right)$ by using the following equation: ${ }^{\circ} \mathrm{F}=1.8\left({ }^{\circ} \mathrm{C}\right)+32$. 


\title{
Hydrogeology of, and Quality and Recharge Ages of Ground Water in, Prince William County, Virginia, 1990-91
}

\author{
By David L. Nelms and Allen R. Brockman
}

\section{Abstract}

Prince William County, Virginia, a rapidly growing suburban area near Washington, D.C., includes parts of four distinct geologic provinces: (1) the Blue Ridge, (2) the Culpeper Basin, (3) the Piedmont, and (4) the Coastal Plain. The hydrogeology is complex and is characterized by ground-water-flow systems in both consolidated rocks and unconsolidated material. A hydrogeologic framework for the county was developed by dividing the rocks in the four geologic provinces into seven hydrogeologic groups on the basis of factors that affect the presence and movement of ground water. Generally, the ground-water systems in the county are recharged in elevated areas between stream valleys and discharge to streams and estuaries. The paths and rate of flow of water in consolidated rocks and unconsolidated materials are distinctly different.

The quality of ground water in Prince William County varies across the county. The rocks in the Blue Ridge, Piedmont, and Coastal Plain contain minerals that are resistant to weathering, and the ground water tends to be acidic having low concentrations of dissolved constituents. The rocks in the Culpeper Basin contain abundant soluble minerals, and the ground water tends to be basic, usually having the highest concentrations of dissolved constituents. Dissolved oxygen concentration in ground water tends to be high in the fractured-rock systems, especially in the Blue Ridge. The abundance of the different ionic species in ground water varies between and within the different hydrogeologic groups. For tl 9 most part, calcium is the predominant cation and bicarbonate is the predominant anion in grounc water of the county. Generally, ground water is soft to moderately hard in the Blue Ridge, Piedmont, and Coastal Plain and soft to very hard in the Culpeper Basin. Sulfate concentration in the ground water in the Culpeper Basin are the highest in response to the abundance of gypsum. Nutrient concentration in ground water is low. The only metals that were detected at substantial concentrations in ground water in the county are barium, iron, manganese, strontium, and zinc. The presence and distribution of radon-222 in ground water are extremely varied and terd to be highest in the rocks of the Piedmont. Established drinking-water standards were exceeded in water samples from wells for $\mathrm{pH}$ ( 28 percent of the samples), sulfate ( 8 percent), chloride ( 1 percent $)$, total dissolved solids (12 percent), iron (10 percent), manganese (18 percent), zinc (1 percent), and radon-222 (93 percent).

The presence of chlorofluorocarbons (CFC's) in ground water in parts of the flow systems in Prince William County indicates that the water is younger than 45 years, especially in the consolidated-rock aquifers. Because groundwater samples were commonly contaminated by CFC's at concentrations greater than those in the present-day atmosphere, however, precise dating of water from wells in urban settings was not possible. High capacity wells tend to have younger recharge ages than those estimated for low' yield domestic wells. The deepest water-producing 
zone that indicated CFC's was 840 feet below land surface in the Culpeper Basin within the high ground-water pumpage area in Manassas and Manassas Park. Some of the youngest CFC'smodel recharge ages and highest tritium concentrations in ground water occur in an area of the Piedmont where the thickness of overburden ranges from 60 to 110 feet. Evidently, macropores or remnant rock fabric in the saprolite at land surface and at shallow depths allow for rapid movement through the unconsolidated part of the ground-water-flow system in this part of the Piedmont. Stratification of CFC's-model recharge ages is evident in the Coastal Plain. The CFC's-model recharge ages can aid in the evaluation of ground-water resources and in the interpretation of differences detected in water-quality analyses of ground water. Water-resource planners can use recharge ages to effectively design management and protection strategies for their ground-water resources.

\section{INTRODUCTION}

Future urbanization of Prince William County, Va., a rapidly growing suburb of Washington, D.C., is expected to increase the demand for water resources. Because increasing real estate values and the presence of sensitive ecosystems along rivers will make reservoir construction less feasible, the county will probably have to rely either on water purchased from neighboring counties or municipalities, or on ground water to meet future water-supply demands. Available data on ground-water quality in the county were inadequate to allow a full evaluation of ground-water resources, protection strategies, contamination, and remediation alternatives. In 1990, the U.S. Geological Survey (USGS), in cooperation with the Prince William Health District, began a study of the quality of ground water to generate the data needed to make this evaluation and to establish a baseline for evaluating the as yet undeveloped ground-water resources in the county.

\section{Purpose and Scope}

This report presents a description of the hydrogeology, the ground-water quality, and the ages of ground-water recharge in Prince William County, Va. The hydrogeology of the county is discussed in terms of the hydrogeologic framework and grount-waterflow systems, and water-bearing potential of the consolidated rocks and unconsolidated materials. Current ground-water quality is characterized for the different hydrogeologic settings on the basis of analyses of 88 samples from 87 wells. In addition, the statistical and spatial distribution of major properties and constituents, types of water, and recharge ages of ground water are discussed.

The basic data used for this study, including well-construction information, ground-water levels, and water-quality analyses are not included in this report. These data, collected between 1990 and 1991 along with a description of the sample collection and analysis methods, are presented in Nelms and Brockman (1993).

\section{Location of Study Area}

Prince William County is in Northerr Virginia, about $25 \mathrm{mi}$ southwest of Washington, D.C. It is bordered by Loudoun and Fairfax Counties to the north, Fauquier County to the west, Stafford County to the south, and the Potomac River estuary and th - State of Maryland to the east (fig. 1). The study area, Prince William County, encompasses about $347 \mathrm{mi}^{2}$ and in 1990 had a population of about 215,000 . From west to east, the county includes parts of four distinct geologic provinces: (1) the Blue Ridge, (2) the Culpeper Basin, (3) the Piedmont, and (4) the Coastal Plain (fig. 1). An estimated $6.46 \mathrm{Mgal} / \mathrm{d}$ of water is consumed in the county (Kull, 1983).

\section{Previous Studies}

Several geologic investigations have been conducted in Prince William County and adjacent areas. Lee $(1979,1980)$ mapped the Triassic-Jurassic geology of the Culpeper Basin of the Piedmont Physiographic Province in parts of 34 quadrangles at a scale of 1:24,000. Mixon and others (1972) and Seiders and Mixon (1981) mapped the Coastal Plain and eastern Piedmont Physiographic Provinces of the county, 


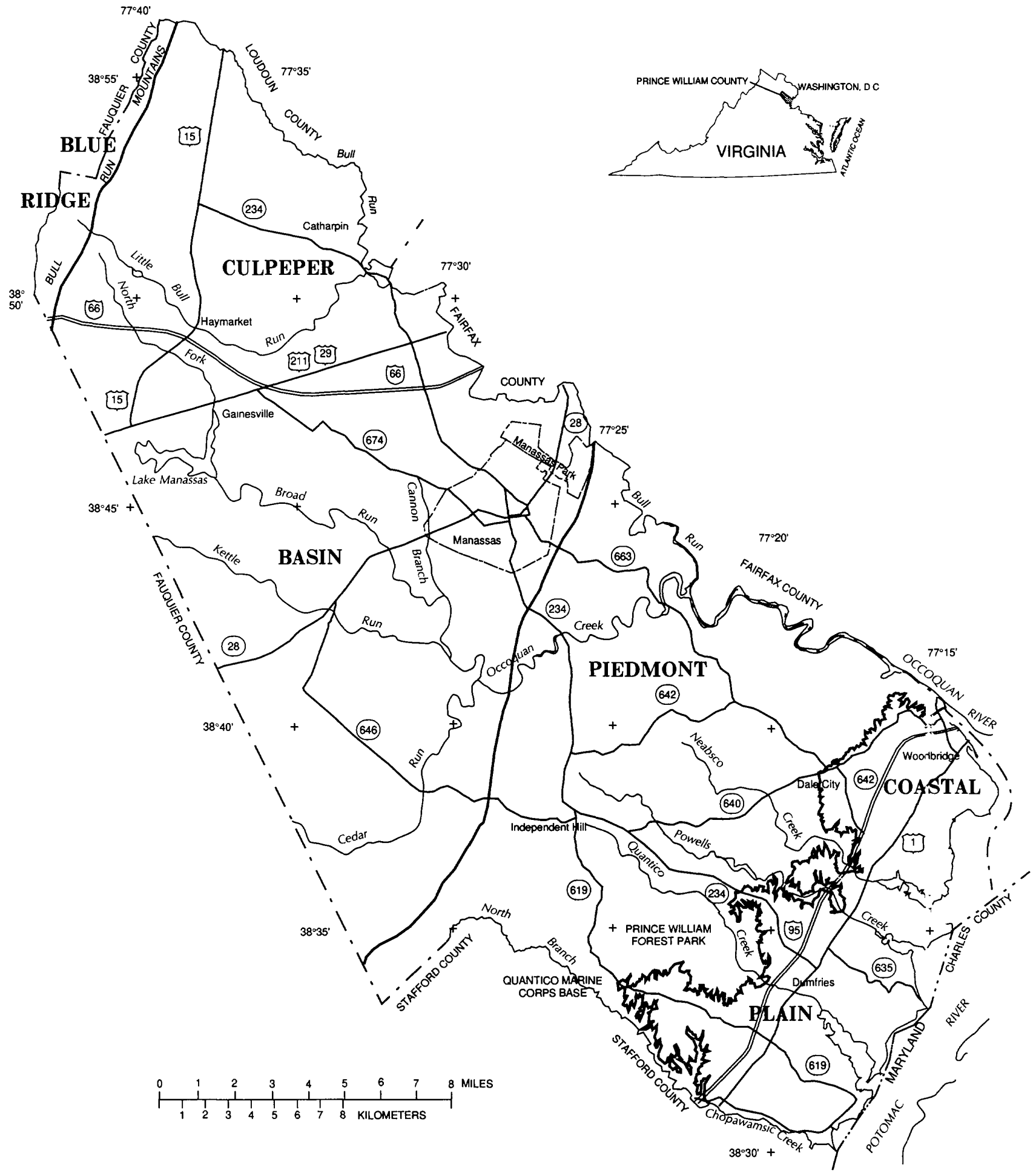

Figure 1. Location of study area and geologic provinces in Prince William County, Virginia. 
also at a scale of 1:24,000. Lee and Froelich (1989) described the Triassic-Jurassic stratigraphy of the Culpeper and Barboursville Basins. Pavlides (1990) mapped the geology in the Piedmont of Northern Virginia at a scale of 1:100,000.

Other investigations have focused on the hydrology of Prince William County and adjacent areas. Cady $(1933,1938)$ presented the first comprehensive investigation of the ground-water resources of Northern Virginia. An assessment of the ground-water resources of the county was conducted by Comer (1976) for the Virginia Department of Environmental Quality (DEQ), formerly the Virginia State Water Control Board (VWCB). Geraghty and Miller, Incorporated (1978), investigated the availability of ground water for public supply in the county. Betz-ConverseMurdoch, Incorporated (1982) completed a groundwater supply study for the county in which 13 sites were selected as potential well fields. Several consulting firms have completed ground-water investigations for private industries located in the county.

Other investigations presented a combined focus on both the geology and hydrology, or hydrogeology, of Prince William County and adjacent areas. Sanford (1913) presented the first integration of geology and ground-water resources of the Virginia Coastal Plain. Johnston (1960) described groundwater supplies in the shale and sandstone of Fairfax, Loudoun, and Prince William Counties, Virginia.

Brown and others (1972) presented regional permeability-distribution maps for geologic units in the Northern Atlantic Coastal Plain. Leavy and others (1983), Posner and Zenone (1983), Leavy (1984), Froelich (1985), Laczniak and Zenone (1985), and Lynch and others (1987) completed parts of a series of studies conducted by USGS examining the hydrology and geology of the Culpeper Basin of the Piedmont. As part of the USGS Regional Aquifer-System Analysis (RASA) of the Northern Atlantic Coastal Plain, Meng and Harsh (1988) delineated the aquifers and confining units of the Virginia Coastal Plain. The nomenclature established by Meng and Harsh, with minor modifications, is used in the description of Coastal Plain hydrogeology in this report. Nelms and Richardson (1990) investigated the extent of volatile organic contaminants in the ground water of the Culpeper Basin in the county.

\section{Study Methods}

Study objectives were accomplished through analysis and synthesis of the available hydrogeologic data, specific to Prince William County, from previous investigations and the additional ambient-waterquality and water-level data collected during this investigation. The analysis of those data consisted of a review of previous reports and well records at the USGS, Virginia DEQ, Prince William Health District, and Prince William County Service Authority. Established methods were followed in the collection of water-level and ambient-water-quality data.

Water levels were measured in 159 wells during two synoptic runs in the spring and fall of 1991 to approximate the seasonal water-level fluctuations. Pumps were shut down for as long as feasitle and the water-level recovery period was recorded. During the fall synoptic run, the recovery duration of th a spring run was duplicated, whenever possible. At least three water-level measurements were made at a w'ell during each synoptic run. At least two measurements had to be identical for the water level to be recorded as a static level. For wells that had not completely recovered, a series of measurements were collected until the difference between measurements was less than $0.5 \mathrm{ft}$, and the water level was reported as an approximate static level.

Ground-water samples were collected from 87 wells during the summer months of 1990 ard 1991 to characterize the ambient ground-water quality. Procedures outlined in Wood (1976), Scalf and others (1981), and Claassen (1982) were followed during sample collection. Specific conductance, $\mathrm{pI}^{\top}$, dissolved oxygen, and water temperature were monitored in a flow-thru-chamber during the purging $\mathrm{c} f$ each well. Domestic wells were purged either for at least 1 hour or until the field properties had stabilized after the first hour. Public-supply wells generally had been pumped for several hours and were effectively purged prior to the arrival of project personnel; therefore, field properties at these wells were monitored for at least an additional 30 minutes or until stable values were obtained. Any filtration or treatment devices at the well were bypassed, so that a representative water sample from the aquifer could be collected.

Samples collected for major cation, trace metal, and nutrient analyses were filtered through a $0.45-\mu$ membrane filter. Dissolved organic carbon samples were filtered through a $0.45-\mu$ silver filter. Alkalinity was measured in the field by using the fixed endpoint 
$(\mathrm{pH}=4.5)$, electrometric titration method. Radon-222 samples were collected from the flow-thru-chamber using the syringe method described in Cecil and Yang (1987). The basic water-quality samples were analyzed at the USGS National Water Quality Laboratory in Denver, Colo. Methods for the determination of inorganic and organic constituents in water used by the laboratory are documented in Fishman and Friedman (1989) and Wershaw and others (1987). Laboratory quality assurance procedures are outlined in Friedman and Erdmann (1982) and Jones (1987).

Ground-water samples were collected and analyzed for chlorofluorocarbons, tritium $\left({ }^{3} \mathrm{H}\right)$, dissolved gases, and the stable isotopes-deuterium $\left({ }^{2} \mathrm{H}\right)$ and oxygen- $18\left({ }^{18} \mathrm{O}\right)$ to determine the recharge age of ground water within Prince William County and to evaluate the stable isotopic signature. The age of ground water at 57 sites was determined by sampling and analytical methods developed by Busenberg and Plummer (1992), which use chlorofluorocarbons as dating tools. The chlorofluorocarbon, environmental isotope, and dissolved gas samples were analyzed in laboratories maintained by the USGS National Research Program in Reston, Va.

\section{Acknowledgments}

The authors express their appreciation to James Shifflett and Frank McDonough of the City of Manassas Park, Donald Echols and Darrell Grady of the City of Manassas, Earl Smith and James Camper of the Upper Occoquan Sewage Authority, James Fugate of Prince William Forest Park, and James Klackowicz and Donald Barrett of Leesylvania State Park for providing access to wells. The assistance of Ralph Eckley, James Green, David Miller, and Lee Hefner of the Prince William County Service Authority during various phases of this investigation was extremely beneficial. Dean W. Chartrand of IBM provided valuable water-level data for this investigation. The authors would like to thank Marcus Haynes of the Prince William Health District for his input throughout this investigation. Special thanks are expressed also to the citizens of Prince William County who allowed access to their wells.

\section{HYDROGEOLOGY}

The hydrogeology of Prince William County is complex and is characterized by ground-water-flow systems in both consolidated rocks and unconsolidated materials (primarily overburden and weathere 1 bedrock). A conceptual hydrogeologic framework was developed by dividing the rocks of the county into seven hydrogeologic groups (table 1). Conceptualization of the ground-water-flow systems is crucial in the characterization and evaluation of the quality of ground water.

\section{Hydrogeologic Framework}

The hydrogeologic framework for Prince William County consists of seven hydrogeologic groups based mainly on lithotectonic features, which represent assemblages of rock grouped by lithology', structural features, origin, and historical evolution (Bates and Jackson, 1987). The presence and movement of ground water through the rocks are affected by these lithotectonic features. The spatial distribution of the hydrogeologic groups is shown in figure 2 . In terms of geologic provinces, hydrogeologic group A includes rocks of the Blue Ridge; hydrogeologic group : B, B1, and $\mathrm{C}$ include rocks of the Culpeper Basin; hydrogeologic groups D and E include rocks of the Piedmont; and hydrogeologic group $\mathrm{F}$ includes unconsolidated material of the Coastal Plain and overburden in the other provinces.

\section{Group A}

Hydrogeologic group A underlies the northwestern part of Prince William County on Bull Run Mountain, which is part of the Blue Ridge geologic province, and consists of Early Cambrian metasedimentary rocks found in the Chilhowee Group: Antietam, Harpers, and Weverton Formations. Tho predominant rock types are quartzite and phyllite. The Chilhowee Group is a basal sequence of clastic sediments, terrigenous and near-shore marine in origin, deposited along the Cambrian continental margin on a foundation of Precambrian lava flows of the Catoctin Formation (Espenshade, 1986; Pavlides, 1989, p. 185; Rankin and others, 1989, p. 32). The Catoctir Formation and the Chilhowee Group are part of the eastern limb of the Blue Ridge Anticlinorium and gererally dip to the east and southeast. Steep slopes with relief of approximately $500 \mathrm{ft}$ and thin to absent cover of 
Table 1. Hydrogeologic group classification for Prince William County, Virginia

[gal/min, gallons per minute; ft, feet]

\begin{tabular}{lllc}
\hline $\begin{array}{c}\text { Hydro- } \\
\text { geologic } \\
\text { group }\end{array}$ & Geologic & Rock & Water-bearing \\
type & Formation & potential $^{3}$ \\
\hline
\end{tabular}

A Blue Ridge Metasedimentary

B

Culpeper Basin Sedimentary

Bl Culpeper Basin

Sedimentary (well depth greater than $500 \mathrm{ft}$ )

C

Culpeper Basin $\quad \begin{aligned} & \text { Igneous and } \\ & \text { metamorphic }\end{aligned}$

D Piedmont

E

Piedmont
Metasedimentary, metavolcanic, and metadiamictite

$\mathrm{F}$

$$
\begin{aligned}
& \text { Coastal Plain } \\
& \text { and other } \\
& \text { provinces }
\end{aligned}
$$

Chilhowee Group Antietam Formation Harpers Formation Weverton Formation

Waterfall Formation Millbrook Quarry Member

Turkey Run Formation

Midland Formation

Catharpin Creek Formation Goose Creek Member

Balls Bluff Siltstone ${ }^{1}$

Manassas Sandstone ${ }^{1}$

Poolesville Member ${ }^{1}$

Reston Member

Balls Bluff Siltstone

Manassas Sandstone Poolesville Member

Sander Basalt

Hickory Grove Basalt

Mount Zion Church Basalt

Thermally metamorphosed rocks

Diabase

Igneous-metaplutonic Metatonalite ${ }^{2}$

Occoquan Pluton ${ }^{2}$

Lake Jackson Pluton ${ }^{2}$

Goldvein Pluton

Quantico Formation

Popes Head Formation

Phyllite $^{2}$

Lunga Reservoir Formation

Purcell Branch Formation

Sykesville Formation

Chopawamsic Formation

Holocene alluvium and colluvium

Tabb Formation

Aquia Formation

Potomac Formation
Poor. Massive bedding and lack of well developed open fractures. Thin cover of overburden. Significant yields in upland draws. Yields range from 4 to $75 \mathrm{gal} / \mathrm{min}$.

Moderate to excellent. Closely to widely spaced fractures and bedding-plane partings with high frequency of intersections Dissolution of calcite along fractures. Yields range from 0.5 to $740 \mathrm{gal} / \mathrm{min}$.

Same as hydrogeologic group B.

Generally poor. Massive to platy, random fracture orientations, and wide spacing between fractures. Some fractures mineralized. Locally may have significant yields associated with cross-strike features and columnar joints. Yields range from 0.35 to $110 \mathrm{gal} / \mathrm{min}$.

Moderate. Subhorizontal sheeting and nearvertical joints overlain by thick overburden. Yields range from 1.2 to $100 \mathrm{gal} / \mathrm{min}$.

Poor to moderate. Near-vertical joints overlain by thin to thick overburden. Lack of well-developed open fractures, especially in phyllite and slate. Yields range from 0.25 to $70 \mathrm{gal} / \mathrm{min}$.

Very good to excellent. Porous media flow. Yields tend to be high for wells in the deeper formations. Potential exists for intrusion of brackish surface water. Yields range from 12 to $320 \mathrm{gal} / \mathrm{min}$.

\footnotetext{
'Well depth less than $500 \mathrm{ft}$.

2 Unit follows usage of U.S. Geological Survey Open-File Report 90-548 (Pavlides, 1990).

${ }^{3}$ Modified from Nelms and Richardson (1990).
} 


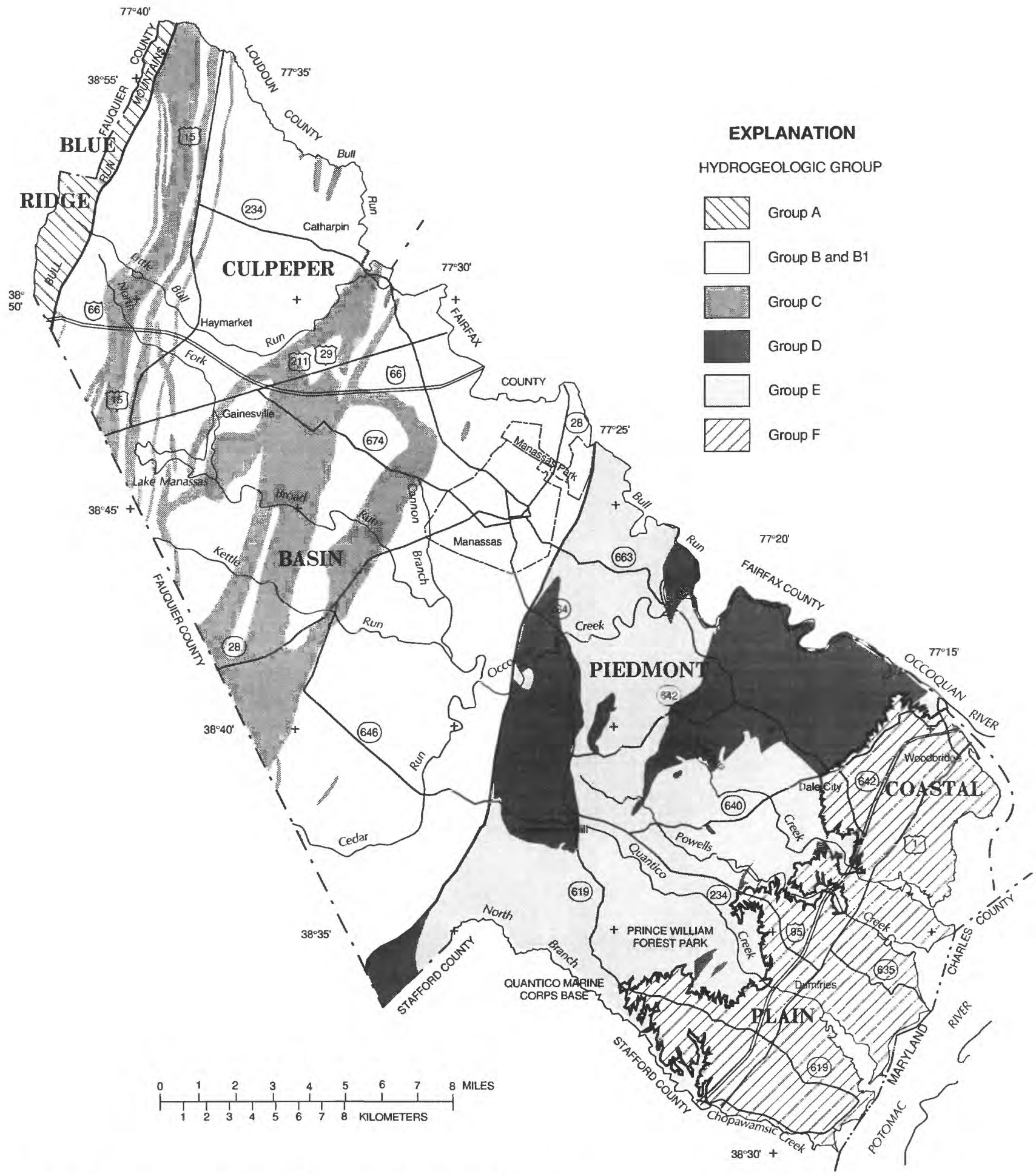

Figure 2. Hydrogeologic groups in Prince William County, Virginia. 
overburden are characteristic features. Rocks within hydrogeologic group A tend to have poor waterbearing potential because of the massive bedding in the quartzite, and the lack of well-developed open fractures in the phyllite. Significant yields, however, have been obtained from wells located in upland draws. Because of the thin to absent cover of overburden, ground-water storage predominantly is in the fractures in the bedrock. Areas underlain by Quaternary mountain-wash deposits along the base of Bull Run Mountain may have ground water stored in these deposits.

\section{Group B}

Hydrogeologic group B underlies the western part of Prince William County and consists of sedimentary rocks of the Culpeper Basin, which are the Late Triassic Manassas Sandstone and Balls Bluff Siltstone; the Late Triassic to Early Jurassic Catharpin Creek Formation; and the Early Jurassic Midland, Turkey Run, and Waterfall Formations. The predominant rock types are conglomerates, sandstones, siltstones, shales, and argillaceous limestones. These rocks were deposited in alluvial fan, fluvial, and lacustrine environments. The arkosic nature of the sandstones, and the presence of caliche and evaporitic deposits, such as gypsum, suggest that the Culpeper Basin was once a closed basin that formed in an arid to semiarid climate (Smoot, 1989, p. 2; Gore and others, 1989, p. 60 ). The basin is separated from the Blue Ridge Anticlinorium to the west by east-dipping listric faults and bordered on the east by minor faults and by unconformable onlap over rocks of early Paleozoic age (Gore and others, 1989, p. 59). The rocks dip to the west and northwest at 0 to $70^{\circ}$, with the dips progressively steepening westward in the basin, toward the western border fault. Closely spaced fractures and bedding-plane partings with a high frequency of intersections overlain by a thin cover of overburden are characteristic features (Nelms and Richardson, 1990). Rocks within hydrogeologic group B tend to have moderate to excellent water-bearing potential because of the close spacing and high frequency of intersections of fractures and partings. Ground-water storage tends to be predominantly in the fractures and partings of the rock because of the extremely thin cover of overburden. The highest reported yields in the county are from wells finished in the rocks of hydrogeologic group B. Wells that are less than $500 \mathrm{ft}$ in depth in the Poolesville Member of the Manassas
Sandstone and Balls Bluff Siltstone were included in this group.

\section{Group B1}

Hydrogeologic group B1 is a subset of group B and wells that are greater than $500 \mathrm{ft}$ in depth in the Poolesville Member of the Manassas Sandstone and Balls Bluff Siltstone were included in this group. The rock types, deposition, structure, and water-bearing potential are the same as described for group B; except the presence of evaporitic minerals in lake bed sediments tends to increase at depths that exceed $500 \mathrm{ft}$ (A.J. Froelich, U.S. Geological Survey, oral commun., 1990). The evaporite, gypsum $\left(\mathrm{CaSO}_{4}\right)$, commonly is present at these depths.

\section{Group C}

Hydrogeologic group $\mathrm{C}$, which extends throughout the area of groups B and B1, in western Prince William County, consists of igneous rocks (basalt and diabase) of the Culpeper Basin and sedimentary units incorporated within or thermally metamorphosed along contacts with the diabase. The rocks of group $C$ are Early Jurassic in age and include: the Mount Zion Church, Hickory Grove, and Sander Basalts; an unnamed diabase; and thermally metamorphosed rocks. The predominant rock types are basalt, sandstone, siltstone, diabase, hornfels, and granofels. The basalts were deposited in lava flows, and the diabases were magmas intruded into the host sedimentary rocks as dikes, sills, and stocks (Gore and others, 1989, p. 60; Nelms and Richardson, 1990, p. 12). Welldeveloped, widely spaced and subhorizontal joints generally overlain by thin cover of overburden are characteristic features of the diabase. Well-developed columnar joints overlain by a thin cover of overburden are characteristic features of the basalt. Thin to thick bedding with a thin cover of overburden are characteristic features of the thermally metamorphosed rocks (Lee and Froelich, 1989; Nelms and Richardson, 1990). Rocks within hydrogeologic group $C$ tend to have generally poor water-bearing potential because of the wide spacing between fractures, mineralization of fractures, and random fracture orientations. Significant yields have been obtained from wells finished in areas where the diabase is intersected by cross-strike lineaments (Nelms and Richardson, 1990, p. 25) and in areas underlain by basalt. 


\section{Group D}

Hydrogeologic group D consists of three igneous plutons in the eastern part of Prince William County: the Goldvein, Lake Jackson, and Occoquan Plutons. The plutons are Ordovician in age and the predominant rock types are metatonalite and metamonzogranite (Pavlides, 1989; 1990). The plutons were magmas intruded into the Chopawamsic backarc basin sediments during a compressive-tectonic phase (Hopson, 1964, p. 202; Pavlides, 1989). Parts of the plutons cut across the surrounding metasedimentary rocks (Seiders and Mixon, 1981), locally interrupting ground-water flow and quality trends. Subhorizontal sheeting and near vertical joints overlain by a thick cover of overburden in the form of saprolite, which is weathered bedrock, are characteristic features. Rocks within hydrogeologic group D tend to have moderate water-bearing potential because of the sheeting and near-vertical joints overlain by thick cover of overburden. No relation between yield and either thickness of overburden or depth was evident for wells in the county that are finished in the rocks of group D. Because of the greater amount of void space present in the overburden than in the bedrock ground-water storage tends to be predominantly in the overburden.

\section{Group E}

Hydrogeologic group E underlies the eastern part of Prince William County and consists of metasedimentary, metavolcanic, and other metamorphic rocks including the Cambrian Chopawamsic Formation; the Ordovician or Cambrian (or both) Lunga Reservoir, Purcell Branch, and Sykesville Formations; the Ordovician Popes Head and Quantico Formations; and an unnamed phyllite, also Ordovician in age. The predominant rock types are amphibolite gneiss, metadiamictite, phyllite, metasiltstone, and slate. These rocks were deposited either by contemporaneously Cambrian volcanic activity at the Chopawamsic island-arc chain, located at what is now the eastern edge of the county, or through the reworking of the volcanic debris (Pavlides, 1981;1989). The metadiamictites collected in submarine fans in a back-arc marine basin located now to the west of the remnants of the island-arc (Pavlides, 1989, p. 181). Beginning in the Middle-to-Late Cambrian time, segments of the island-arc were overthrust onto the back-arc sediments when the back-arc basin began constricting (Pavlides, 1989, p. 185). The Lunga Reservoir and equivalent formations form part of the western flank of the Baltimore-Washington Anticlinorium and dip to the west and northwest at 25 to $85^{\circ}$ (Seiders and Mixon, 1981). Near-vertical joints and thin to thick cover of overburden are characteristic features. Rocks within hydrogeologic group $\mathrm{E}$ tend to have poor to moderate water-bearing potential because of the near-vertical joints, lack of well-developed open fractures (especially in the phyllite and slate), and thin- to thickcover of overburden. Similar to the rocks of hydrogeologic group D, ground-water storage tends to be predominantly in the overburden.

\section{Group F}

The majority of hydrogeologic group $\mathrm{F}$ is present in a band, approximately $5 \mathrm{mi}$ in width, at the eastern extreme of Prince William County to the east of the Fall Zone. Hydrogeologic group F drapes over hydrogeologic groups $\mathrm{D}$ and $\mathrm{E}$ near the Fall Zone. Also grouped with hydrogeologic group $\mathrm{F}$ is the unconsolidated material overlying the bedrock, which is classified as "overburden" in this report, throughout the county west of the Fall Zone. Hydrogeologic group $\mathrm{F}$ includes the Early Cretaceous Potomac Formation, the Paleocene Aquia Formation, the Pleistocene Tabb Formation, and the Holocene alluvium and colluvium. The predominant sediment or rock types are sand, silt, clay, lignite, gravel, soil, and weathered bedrock (saprolite). The Cretaceous, Paleocene, and Pleistocene sediments were deposited in fluvial, estuarine, and marine settings. Holocene sediments are collecting as soils, stream alluvium, and marsh deposits. Part of hydrogeologic group D underlying group $\mathrm{F}$ in eastern Prince William County was compressed into the Quantico Synclinorium during the Ordovician Period, and in this area the Chopawamsic Formation dips to the east and southeast at 60 to $85^{\circ}$ (Seiders and Mixon, 1981). In this eastern section of the county, the Stafford fault system consists of a series of northeast-trending, high-angle reverse faults in group F sediments. These faults formed by compressional stress from Cretaceous to earliest Quaternary time (Mixon and Newell, 1977; Seiders and Mixon, 1981). Maximum vertical displacements along the fault system range from 100 to $200 \mathrm{ft}$ (Seiders and Mixon, 1981) and can offset both groundwater yielding fractures and unconsolidated aquifers in the Coastal Plain. Conversely, the faults can serve as alternate conduits for ground-water flow. The unconsolidated material within hydrogeologic group F 
tends to have very good to excellent water-bearing potential because of the abundance of interconnected voids. Wells that produce from sediments of the Potomac Formation tend to have high yields. Potential development of the ground-water resources within the Coastal Plain is uncertain because of the limited areal extent of the unconsolidated material and possible interconnection between the aquifers and the Potomac River.

\section{Ground-Water-Flow Systems}

Ground water flows through the connected voids in rocks and sediments. In unconsolidated material, such as the overburden and the sediments of the Coastal Plain in Prince William County, voids between the sediment grains resulted from weathering of bedrock or remain from the time when the sediments were deposited. Consolidated rocks (all other rock units in the county), commonly referenced to as "bedrock," contain voids resulting from fracturing after the rocks were formed. The percentage of voids or pore space in the rock is the porosity, and the measure of the connection between the voids is the permeability of the rock. Voids and their degree of connection in unconsolidated material are referred to as "primary" porosity and permeability; in consolidated rocks, they are termed "secondary" porosity and permeability.

Generally, the ground-water system in the county is recharged in elevated areas between stream valleys or channels and discharges to streams and estuaries. The paths and duration of ground-water flow, however, are distinctly different between consolidated rocks and unconsolidated material. Ground water in consolidated rocks follows a circuitous path from the recharge areas through commonly elaborate fracture systems before discharging to a stream or estuary (fig. 3). In unconsolidated material, ground water generally follows a direct path from the recharge area to the discharge area. Where unconsolidated Coastal Plain sediments overlie consolidated Piedmont rock (eastern Prince William County), ground water from the fractured rock discharges either to streams that have eroded downward to the top of the

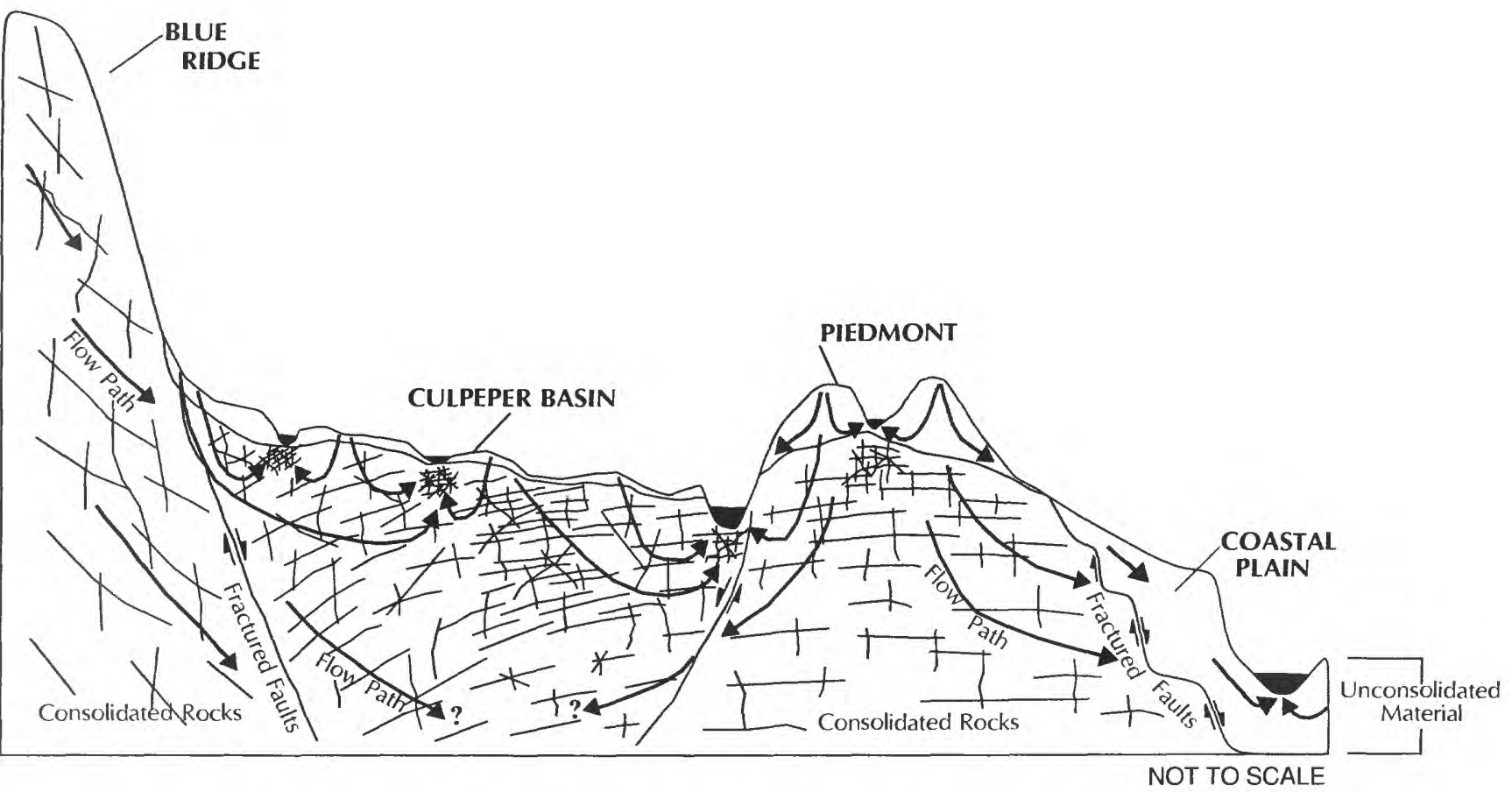

Figure 3. Conceptualization of the ground-water-flow systems in Prince William County, Virginia. 
consolidated rock, or to the Coastal Plain sediments (Cederstrom, 1945; Seymour Subitzky, U.S. Geological Survey, written commun., 1968).

Rates of ground-water flow in either consolidated rock or unconsolidated material are dependent on the hydraulic gradient, hydraulic conductivity (which is in turn dependent on permeability, defined earlier), and aquifer cross-sectional area. Although flowpaths in consolidated rock commonly are circuitous, steep hydraulic gradients and high hydraulic conductivities in well-connected fracture systems can result in a higher rate of ground-water flow in consolidated rock in certain areas than in unconsolidated material of comparatively low hydraulic gradient and hydraulic conductivity where ground-water flow is more directly routed. An understanding of the differences in rates and routes of ground-water flow through consolidated rock in contrast with unconsolidated material is important to understanding the fate of potential contaminants in the two types of groundwater systems (Nelms and Richardson, 1990; Powell and others, 1990).

Within a ground-water system, rocks are divided into aquifers and confining units. Aquifers yield a usable quantity of water to wells or springs; confining units have very low vertical hydraulic conductivities that restrict vertical ground-water flow between aquifers (Heath, 1983).

The top of the shallowest aquifer in the groundwater system is defined by the water table. This aquifer, the upper surface of which is free to rise and decline with changes in barometric pressures, tides, and recharge, is called an unconfined aquifer, or "water-table" aquifer (Heath, 1983). Nelms and Richardson (1990) assumed that the aquifers in the fractured consolidated rocks of the Culpeper Basin are unconfined. The aquifers in fractured consolidated rocks outside the Culpeper Basin and the shallowest aquifer in unconsolidated materials in Prince William County are assumed also to be unconfined for this report. Although the water table across the county defines the top of many distinct - but remotely or directly connected-unconfined aquifers, a map of this surface indicates the horizontal direction of flow between the unconfined aquifers and surface-water bodies. The water table constructed from water-level measurements during October 1991 from 155 wells and from 1,513 elevations of major streams and tributaries depicted on USGS 1:24,000-scale topographic quadrangle maps is shown in figure 4.
Nelms and Richardson (1990, p. 31) noted that seasonal water-level fluctuations in the Manassas/ Manassas Park area tend to be greater than those in other parts of the Culpeper Basin and attributed this to pumpage patterns within this area. Water levels in wells open to confined aquifers exhibit less seasonal fluctuation than water levels in unconfined aquifers, because the low hydraulic conductivities in confining beds above confined aquifers delay and dampen the transmission of seasonal effects from the surface (Mann, p. 110, 1985).

The tops of the aquifers underlying the unconfined aquifer in unconsolidated Coastal Plain sediments are defined by the base of intervening confining beds. Generally, the underlying aquifers are completely filled with water, the water level in wells drilled into each of the aquifers stands above the top of each aquifer, and the aquifers are designated as "confined" (Heath, 1983). Aquifers underlying the watertable aquifer in the unconsolidated Coastal Plain sediments are confined in the Potomac Formation near the Potomac River estuary; these aquifers are in discontinuous, lenticular deposits of fluvial-deltaic origin that were subsequently faulted. A map of water levels in the confined Potomac Formation aquifers is not included in this report because of the sparse data distribution. Part of the aquifer in fractured consolidated rocks in Prince William County is assumed to be confined by thick overburden (Nelms and Richardson, 1990) or the wedge of unconsolidated Coastal Plain sediments, but such a determination was beyond the scope of this study.

Thickness of overburden is another important factor to consider in the evaluation of ground-waterflow systems in Prince William County, especially in the fractured-rock terranes (fig. 5). Overburden is considered to be the unconsolidated material that overlies bedrock and includes colluvium, alluvium, saprolite, and sediments of the Coastal Plain. Figure 5 was constructed from reported thicknesses of overburden at 306 wells. In areas overlain by thin overburden, precipitation can readily infiltrate and percolate through the unconsolidated part of the ground-waterflow system and enter the fractured-rock part, where flow rates are enhanced by the presence of fractures, joints, and bedding-plane partings. Aquifers overlain by a thin cover of overburden will be more susceptible to contamination and to capture of streamflow by pumped wells than areas overlain by thick overburden. In addition, ground-water storage in areas underlain 


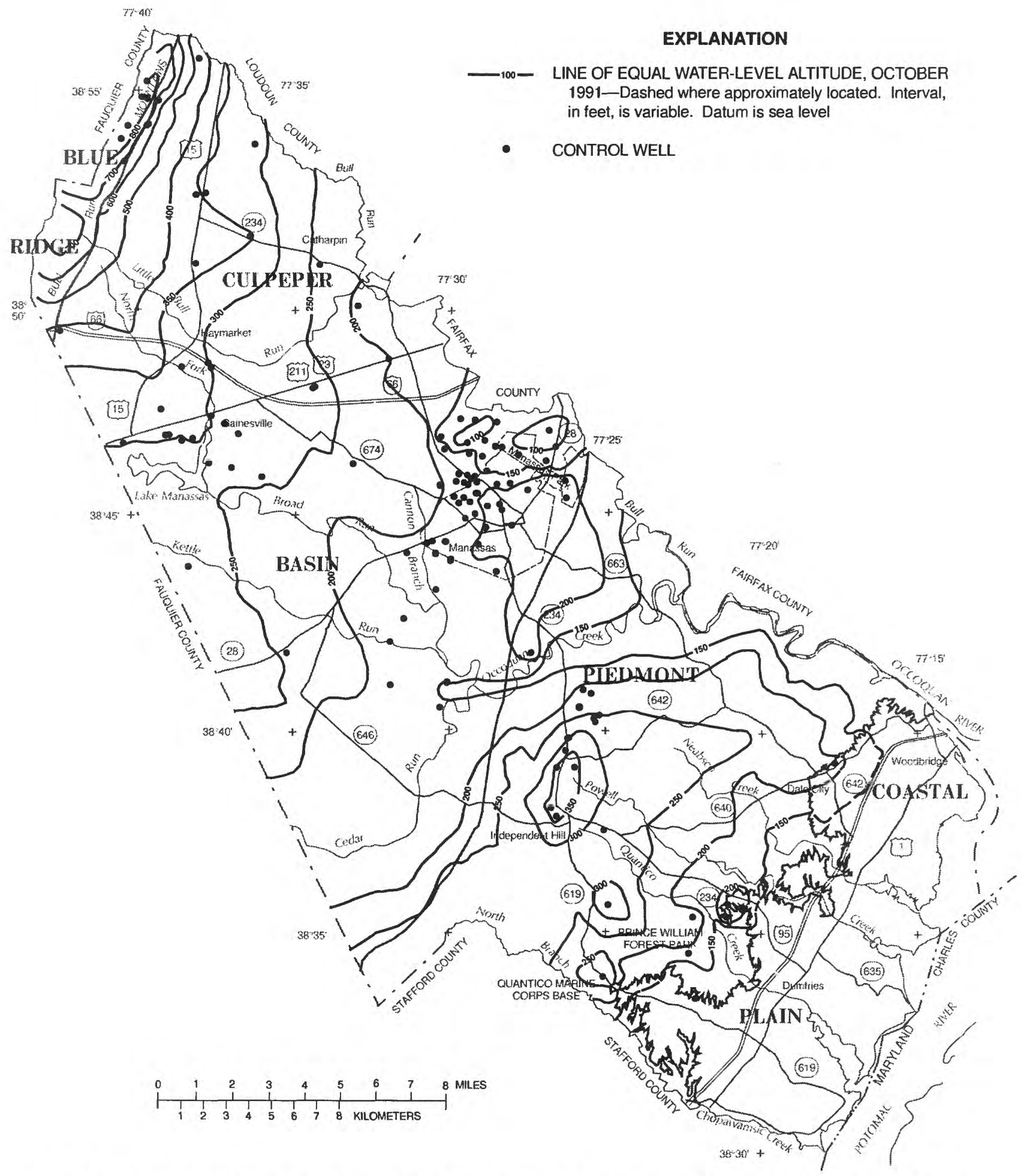

Figure 4. Water-level altitudes in the consolidated-rock aquifers in Prince William County, Virginia, October 1991. 


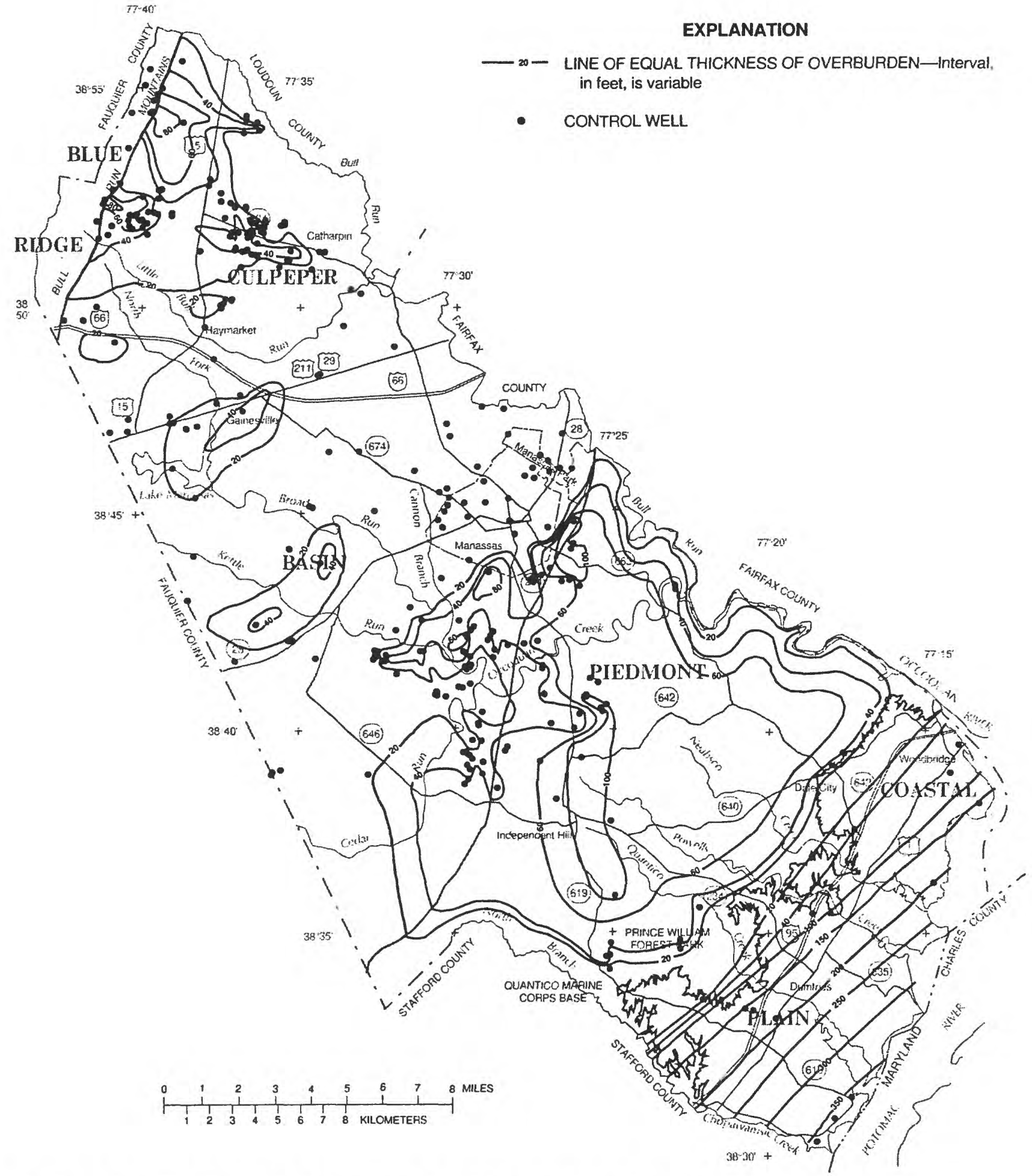

Figure 5. Approximate thickness of overburden in Prince William County, Virginia. 
by thin overburden is predominantly in the fracturedrock part of the ground-water system; whereas, areas overlain by a thick sequence of overburden tend to have storage predominantly in the unconsolidated part of the system. If adequate data were available, structure tops and thicknesses for the individual aquifers and confining units in the Coastal Plain could be shown on a map. The scarcity of data and the complexity of the Coastal Plain sediments and structures within Prince William County made this type of depiction impossible; therefore, the total thickness of the Coastal Plain sediments is not shown on figure 5 . Generally, overburden is (1) thin on Bull Run Mountain (hydrogeologic group A) and across the Culpeper Basin (hydrogeologic groups B, Bl, and C), except along the margins; (2) thick in the areas underlain by crystalline rocks of the Piedmont (hydrogeologic groups D and E); and (3) thickens in a stair-step pattern to the east in the Coastal Plain.

The reported yields of 560 wells in Prince William County range from 0.25 to $735 \mathrm{gal} / \mathrm{min}$ with a median value of $13 \mathrm{gal} / \mathrm{min}$. The statistical distribu- tion of well yields by water-use category for each hydrogeologic group is presented in table 2 . No meaningful relation between well yield and hydrogeologic group can be discerned from the statistical distribution of well yields by using domestic wells or by combining domestic and high-capacity wells. Domestic wells are designed and constructed to meet the water needs of a household; therefore, the optimum siting of the well combined with depth and diameter drilled and use of available drawdown are seldom considered (Cederstrom, 1972, p. 9-10). Median well yields of high-capacity wells tend to be highest in the rocks of hydrogeologic groups B and B1, which can be attributed to the closely spaced fractures, joints, and bedding-plane partings with a high frequency of intersections in the rocks of these groups. Well yields of high capacity wells in hydrogeologic group $\mathrm{C}$ range from 1 to $110 \mathrm{gal} / \mathrm{min}$. Recent drilling in the county indicates that substantial yields can be obtained from wells completed in the basalt and the sedimentary rocks incorporated within these formations. Nelms and Richardson (1990, p. 25) observed that substantial

Table 2. Summary statistics for well yields by hydrogeologic group and water use in Prince William County, Virginia

[values in gallons per minute; - number of observations is less than 12; therefore, a reliable statistic could not be computed]

\begin{tabular}{|c|c|c|c|c|c|}
\hline \multirow{2}{*}{$\begin{array}{l}\text { Hydrogeologic } \\
\text { group }\end{array}$} & \multirow{2}{*}{$\begin{array}{l}\text { Water } \\
\text { use }\end{array}$} & \multirow{2}{*}{$\begin{array}{l}\text { Number of } \\
\text { wells }\end{array}$} & \multicolumn{3}{|c|}{ Well yields } \\
\hline & & & maximum & minimum & median \\
\hline \multirow{3}{*}{ A } & Domestic & 2 & 15 & 6 & - \\
\hline & High capacity & 11 & 75 & 4 & - \\
\hline & Combined & 13 & 75 & 4 & 8.4 \\
\hline \multirow{3}{*}{$\mathrm{B}$ and $\mathrm{Bl}$} & Domestic & 251 & 300 & .5 & 10 \\
\hline & High capacity & 70 & 740 & 8 & 120 \\
\hline & Combined & 321 & 740 & .5 & 15 \\
\hline \multirow[t]{3}{*}{ C } & Domestic & 56 & 100 & .35 & 8 \\
\hline & High capacity & 9 & 110 & 1 & - \\
\hline & Combined & 65 & 110 & .35 & 8 \\
\hline \multirow[t]{3}{*}{ D } & Domestic & 63 & 100 & 1.2 & 7 \\
\hline & High capacity & 12 & 92 & 14 & 24 \\
\hline & Combined & 75 & 100 & 1.2 & 10 \\
\hline \multirow[t]{3}{*}{$\mathrm{E}$} & Domestic & 41 & 60 & 1 & 8 \\
\hline & High capacity & 28 & 70 & .25 & 16 \\
\hline & Combined & 69 & 70 & .25 & 10 \\
\hline \multirow[t]{3}{*}{$\mathrm{F}$} & Domestic & 6 & 50 & 12 & - \\
\hline & High capacity & 11 & 320 & 12 & - \\
\hline & Combined & 17 & 320 & 12 & 73 \\
\hline
\end{tabular}


well yields from the diabase appear to be related to the presence of cross-strike lineaments. The rocks in hydrogeologic groups $\mathrm{D}$ and $\mathrm{E}$ in the Piedmont tend to have low median well yields, 25 and $15 \mathrm{gal} / \mathrm{min}$, respectively. For many years, the idea of terminating wells in the crystalline rocks of the Piedmont at $350 \mathrm{ft}$ below land surface has been followed by water-well drillers and water managers. Recent findings by the USGS, as part of the Appalachian Valley and Piedmont RASA, suggest that substantial yields can be obtained from crystalline rocks of the Piedmont at depths greater than $350 \mathrm{ft}$ (Swain, 1993). These findings of no relation between well yield and depth are supported by other investigations (Cressler and others, 1983; Daniel, 1989; Hansen and Simcox, 1994; Loiselle and Evans, 1995). Well yields in hydrogeologic group F could not be fully evaluated by this investigation because of the lack of data, but wells with substantial well yields have been constructed in this part of the county (table 2).

Declining well yields over time have been observed in wells in Prince William County, especially in the Culpeper Basin (fig. 6). The actual cause of declining well yields is unknown at the present time, but increases in sulfate and total dissolved solids concentrations have been observed as well yields have declined in the Culpeper Basin of Fauquier County (John V. Laws, Fauquier County, oral commun., 1991) and in the Gettysburg Basin of Pennsylvania (Dennis J. Low, U.S. Geological Survey, oral commun., 1996). The combination of physical and chemical processes with increases in demand may explain the declining yields over time.

\section{QUALITY OF GROUND WATER}

The quality of ground water is a reflection of the movement of that water through the hydrologic cycle. Hem $(1985$, p. 1) states that the chemical composition of natural waters is derived from different, yet interrelated, sources such as atmospheric gases, weathering and erosion of soil and rocks, chemical reactions in the subsurface that cause solution and precipitation of solutes, and anthropogenic activities that can add dissolved substances to both precipitation and ground water. Generally, analyses of water from wells and springs provide insight into the sources of dissolved constituents and the pathway(s) travelled by ground water. The initial step in the evaluation of ground-water quality is knowledge of the chemical
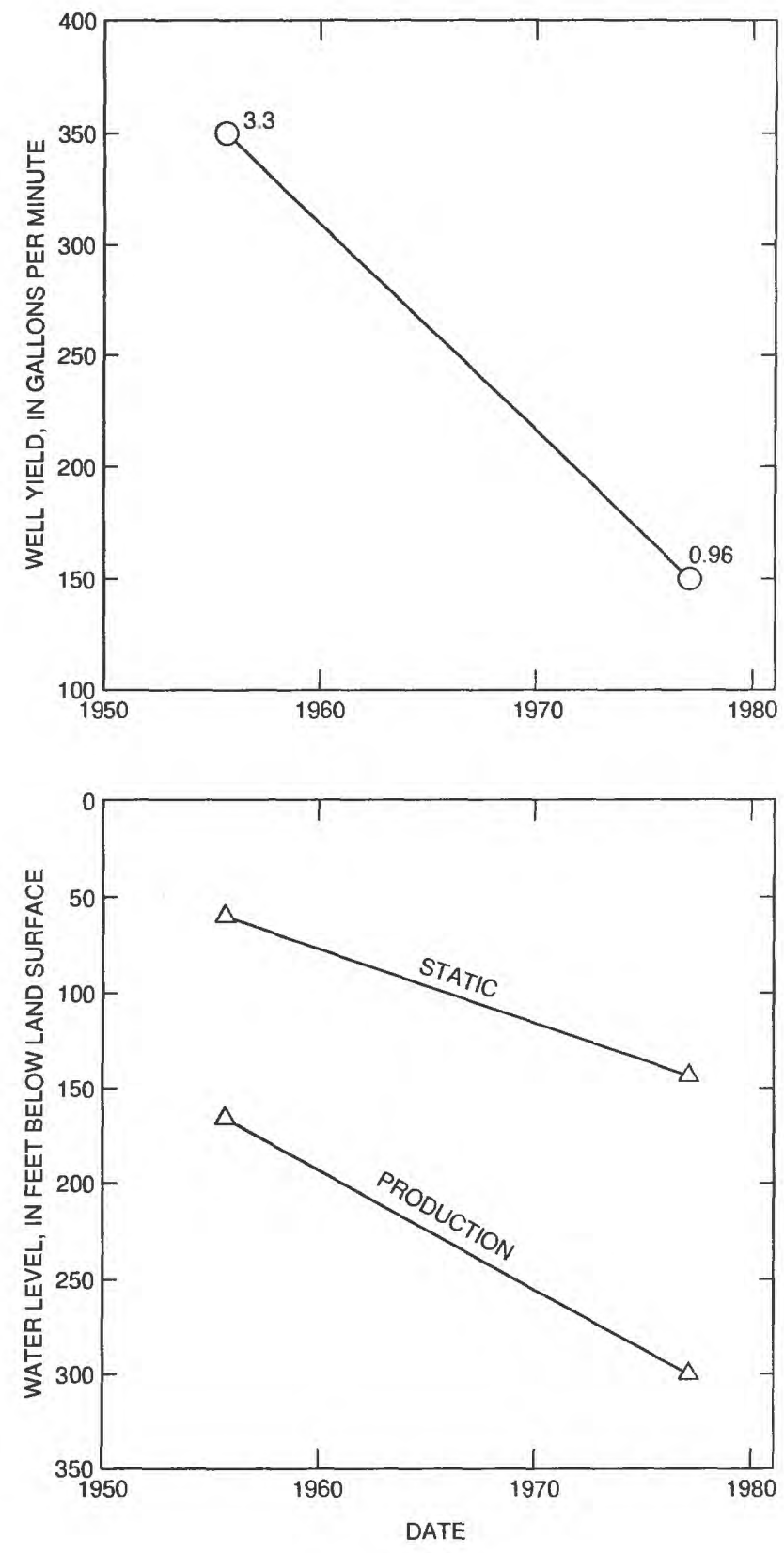

EXPLANATION

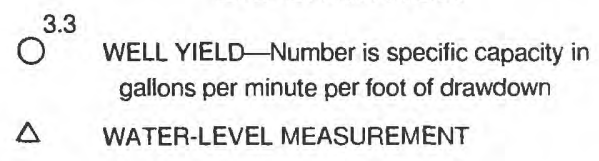

Figure 6. Declining well yield and water levels in well 51 U97H from 1955 to 1977 in Manassas Park, Virginia. 
composition of the input to the ground-water-flow system-precipitation. Precipitation is a dilute solution with low ionic strength, which is evident from table 3 .

Table 3. Average composition of precipitation from the National Atmospheric Deposition Program/National Trends Network (NADP/NTN) station VA28 located in Shenandoah National Park at Big Meadows, Virginia, 1981-92

[source: NADP/NTN home page at http://nadp.nrel.colostate.edu/NADP; concentrations in milligrams per liter, except where noted; $\mu \mathrm{S} / \mathrm{cm}$, microsiemens per centimeter at 25 degrees Celsius]

\begin{tabular}{lc}
\hline Constituent & Concentration \\
\hline pH (standard units) & 4.5 \\
Specific conductance $(\mu \mathrm{S} / \mathrm{cm})$ & 16.9 \\
Calcium & .07 \\
Magnesium & .02 \\
Sodium & .09 \\
Potassium & .02 \\
Sulfate & 1.64 \\
Chloride & .16 \\
Nitrate & .85 \\
\hline
\end{tabular}

The next step in the evaluation of the quality of ground water is to understand and categorize the different geological units based on similar geochemical characteristics. The hydrogeologic groups developed during this investigation are the logical basis for such a categorization because these groups are partly based on lithology or rock type that have similar depositional environments or geochemical origins. The rocks in hydrogeologic groups $(\mathrm{B}, \mathrm{Bl}$, and $\mathrm{C})$ in the Culpeper Basin have an abundance of soluble minerals. The rocks in the Blue Ridge (hydrogeologic group A) and Piedmont (hydrogeologic groups D and E) contain minerals that tend to be resistant to weathering. The unconsolidated materials of the Coastal Plan (hydrogeologic group F) are derived partially from the rocks in the Piedmont and generally have ground-water quality similar to the Piedmont groups. The presence of marine deposits and organic material, however, can affect the water chemistry in the Coastal Plain. The designation of hydrogeologic groups allows for the presence and distribution of major properties and constituents to be described for certain areas of the county rather than the entire county. Variability within groups is to be expected because locally existing rocks or minerals can have a strong affect on the chemical composition of ground water.

\section{Presence and Distribution of Physical Properties and Dissolved Constituents}

The statistical summaries and spatial distributions depicting the presence and distribution of physical properties, selected inorganic constituents, nutrients, metals and trace constituents, dissolved organic carbon, and radon- 222 are discussed in the following sections and the analyses were based on 88 water samples collected from 87 wells throughout Prince William County (fig. 7). Well 49V53 was the only well in the county available to compare the quality of ground water during artesian flow and pumped conditions. Only dissolved constituents are considered in this report and these data are presented in Nelms and Brockman (1993). Summary statistics of physical properties and chemical constituents detected in water samples from wells in the county are summarized in table 4. Drinking-water standards established by the U.S. Environmental Protection Agency (USEPA) are shown in table 4 so the reader can assess the quality of ground water in the county. The Safe Drinking Water Act of 1986 allowed for the establishment of two sets of standards. The maximum contaminant level (MCL) is the maximum permissible level of a constituent set to protect human health and is enforceable by regulatory agencies. The secondary maximum contaminant level (SMCL) is a drinkingwater standard that is nonenforceable and is mainly concerned with the aesthetic and taste characteristics, and usability of water.

The median values of properties and concentrations of dissolved constituents in samples of ground water from rocks in each of the hydrogeologic groups in Prince William County are listed in table 5. The reader should note that median values and concentrations for hydrogeologic groups A, B1, C, and D are calculated from analyses of a limited number of samples and should be used with caution.

\section{Field-Measured Properties}

Field properties- $\mathrm{pH}$, specific conductance, dissolved oxygen, and alkalinity-were measured prior to and during the collection of ground-water samples. All instruments were calibrated at least daily or if weather conditions dramatically changed. Laboratory determinations of $\mathrm{pH}$, specific conductance, and alkalinity were used as quality assurance of the field measurements. The following discussion describes the data from the field measurements because transport to 


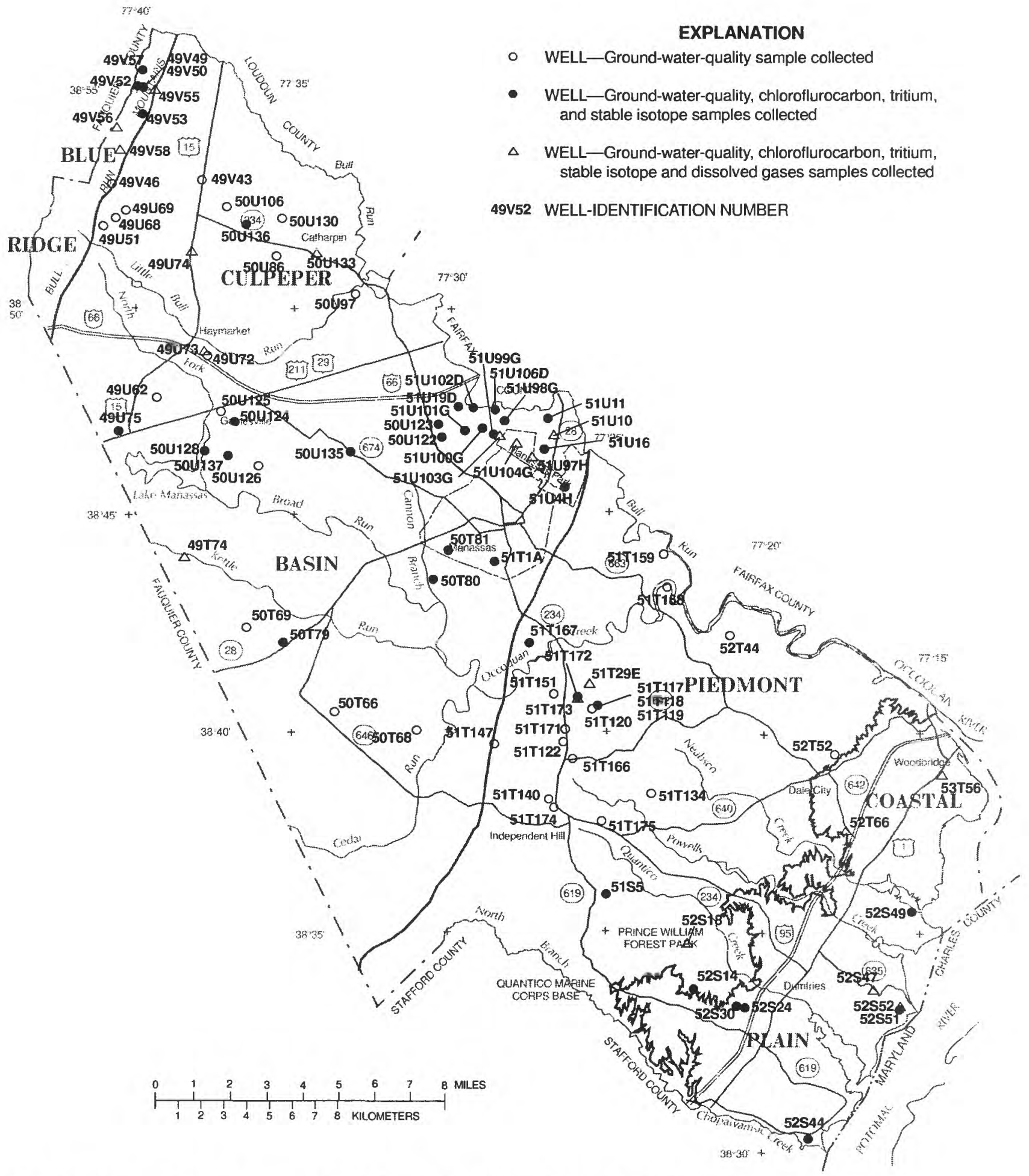

Figure 7. Location of wells sampled in 1990 and 1991 in Prince William County, Virginia. 
Table 4. Summary statistics for analyses of ground-water samples, Prince William County, Virginia, 1990-91

[all analyses are for the dissolved constituent unless otherwise noted; ${ }^{\circ} \mathrm{C}$, degrees Celsius; $\mu \mathrm{S} / \mathrm{cm}$, microsiemens per centimeter at $25^{\circ} \mathrm{C}$ : mg $/ \mathrm{L}$, milligrams per liter: $\mu \mathrm{g} / \mathrm{L}$. micrograms per liter; $\mathrm{pCi} / \mathrm{L}$, picocuries per liter; $\mathrm{CaCO}_{3}$, calcium carbonate; $\mathrm{N}$, nitrogen; $\mathrm{C}$, carbon; $\mathrm{HCO}_{3}$, bicarbonate; <, less than; $\mathrm{MCL}$, maximum contaminant level; SMCL, secondary maximum contaminant level; VGWS, Virginia Ground-Water Standard: $A$, ratio of total dissolved solids to specific conductance; - , no data]

\begin{tabular}{|c|c|c|c|c|c|c|}
\hline Constituent & $\begin{array}{c}\text { Number of } \\
\text { samples }\end{array}$ & $\begin{array}{c}\text { Maximum } \\
\text { concentration }\end{array}$ & $\begin{array}{c}\text { Minimum } \\
\text { concentration }\end{array}$ & $\begin{array}{c}\text { Median } \\
\text { concentration }\end{array}$ & $\begin{array}{c}\mathrm{MCL}^{1}, \\
\mathrm{SMCL}, \\
\text { or } \\
\mathrm{VGWS^{2 }}\end{array}$ & $\begin{array}{c}\text { Number of } \\
\text { samples } \\
\text { exceeding } \\
\text { MCL or } \\
\text { SMCL }\end{array}$ \\
\hline $\mathrm{pH}$, standard units & 88 & 9.5 & 5.1 & 7.2 & $6.5-8.5$ & 23,2 \\
\hline Specific conductance, $\mu \mathrm{S} / \mathrm{cm}$ & 88 & 1,500 & 10 & 300 & - & - \\
\hline Dissolved oxygen, mg/L & 88 & 8.7 & 0.0 & 3.6 & - & - \\
\hline Alkalinity, $\mathrm{mg} / \mathrm{L}$, as $\mathrm{CaCO}_{3}$ & 88 & 290 & 6 & 123 & - & - \\
\hline Temperature, ${ }^{\circ} \mathrm{C}$ & 88 & 24.0 & 10.5 & 15.0 & - & - \\
\hline Hardness. $\mathrm{mg} / \mathrm{L}$, as $\mathrm{CaCO}_{3}$ & 88 & 700 & 0 & 120 & - & - \\
\hline Calcium, mg/L & 88 & 240 & .07 & 34 & - & - \\
\hline Magnesium, mg/L & 88 & 67 & .02 & 7.9 & - & - \\
\hline Sodium, mg/L & 88 & 86 & 1.1 & 12 & 270 & 0 \\
\hline Potassium, mg/L & 88 & 10 & $<.1$ & .9 & - & - \\
\hline Bicarbonate, $\mathrm{mg} / \mathrm{L}$, as $\mathrm{HCO}_{3}$ & 85 & 353 & 8 & 161 & - & - \\
\hline Sulfate, $\mathrm{mg} / \mathrm{L}$ & 88 & 800 & $<1.0$ & 7.8 & 500,250 & 1,7 \\
\hline Chloride, $\mathrm{mg} / \mathrm{L}$ & 88 & 370 & .6 & 7.2 & 250 & 1 \\
\hline Fluoride, mg/L & 88 & .60 & $<.10$ & $<.10$ & 2 & 0 \\
\hline Silica, $\mathrm{mg} / \mathrm{L}$ & 88 & 60 & 7.3 & 27 & - & - \\
\hline \multicolumn{7}{|l|}{ Total dissolved solids, } \\
\hline sum of constituents, mg/L & 88 & 1,280 & 15 & 198 & 500 & 11 \\
\hline A & 88 & 2.8 & .52 & .71 & - & - \\
\hline Nitrite + Nitrate, $\mathrm{mg} / \mathrm{L}$, as $\mathrm{N}$ & 87 & 5.90 & $<.050$ & .300 & 10 & 0 \\
\hline Phosphorus, mg/L & 87 & .630 & $<.010$ & .020 & - & - \\
\hline Aluminum, $\mu \mathrm{g} / \mathrm{L}$ & 88 & 20 & $<10$ & $<10$ & 50,200 & 0 \\
\hline Barium, $\mu g / L$ & 88 & 1,000 & $<2$ & 44 & 2,000 & 0 \\
\hline Iron, $\mu \mathrm{g} / \mathrm{L}$ & 88 & 13,000 & $<3$ & 8 & 300 & 9 \\
\hline Manganese, $\mu \mathrm{g} / \mathrm{L}$ & 88 & 420 & $<1$ & 3 & 50 & 16 \\
\hline Strontium, $\mu \mathrm{g} / \mathrm{L}$ & 88 & 6,200 & $<1$ & 95 & - & - \\
\hline Radon-222, $\mathrm{pCi} / \mathrm{L}$ & 88 & 6,200 & $<80$ & 1,400 & 300 & 82 \\
\hline Dissolved organic carbon, $\mathrm{mg} / \mathrm{L}$, as $\mathrm{C}$ & 88 & 1.9 & .2 & .4 & 1 & 5 \\
\hline Arsenic, $\mu \mathrm{g} / \mathrm{L}$ & 88 & 5 & $<1$ & 1 & 50 & 0 \\
\hline Beryllium, $\mu \mathrm{g} / \mathrm{L}$ & 88 & 1 & $<.5$ & $<.5$ & 4 & 0 \\
\hline Cadmium, $\mu \mathrm{g} / \mathrm{L}$ & 88 & 3 & $<1$ & $<1$ & 5 & 0 \\
\hline Chromium, $\mu \mathrm{g} / \mathrm{L}$ & 88 & $<5$ & $<5$ & $<5$ & 100 & 0 \\
\hline Cobalt, $\mu \mathrm{g} / \mathrm{L}$ & 88 & $<3$ & $<3$ & $<3$ & - & - \\
\hline Copper, $\mu \mathrm{g} / \mathrm{L}$ & 88 & 250 & $<10$ & $<10$ & 1,000 & 0 \\
\hline Lead, $\mu \mathrm{g} / \mathrm{L}$ & 88 & 10 & $<10$ & $<10$ & 15 & 0 \\
\hline Lithium, $\mu \mathrm{g} / \mathrm{L}$ & 88 & 58 & $<4$ & 8 & - & - \\
\hline Mercury, $\mu \mathrm{g} / \mathrm{L}$ & 87 & .1 & $<.1$ & $<.1$ & 2 & 0 \\
\hline Molybdenum, $\mu \mathrm{g} / \mathrm{L}$ & 88 & 20 & $<10$ & $<10$ & - & - \\
\hline Nickel, $\mu \mathrm{g} / \mathrm{L}$ & 88 & 10 & $<10$ & $<10$ & 100 & 0 \\
\hline Silver, $\mu \mathrm{g} / \mathrm{L}$ & 88 & 3 & $<1$ & $<1$ & 100 & 0 \\
\hline Vanadium, $\mu \mathrm{g} / \mathrm{L}$ & 88 & 33 & $<6$ & $<6$ & - & - \\
\hline Zinc, $\mu \mathrm{g} / \mathrm{L}$ & 88 & 7,100 & $<3$ & 10 & 5,000 & 1 \\
\hline
\end{tabular}

'U.S. Environmental Protection Agency (1995).

${ }^{2}$ Southeast Virginia Planning District Commission, (1990). 
Table 5. Median composition of ground water for each hydrogeologic group, Prince William County, Virginia, 1990-91

[all analyses are for the dissolved constituent unless otherwise noted; ${ }^{\circ} \mathrm{C}$, degrees Celsius; $\mu \mathrm{S} / \mathrm{cm}$, microsiemens per centimeter at $25^{\circ} \mathrm{C} ; \mathrm{mg} / \mathrm{L}$, milligrams per liter; $\mu \mathrm{g} / \mathrm{L}$, micrograms per liter; $\mathrm{pCi} / \mathrm{L}$, picocuries per liter; $\mathrm{CaCO}_{3}$, calcium carbonate; $\mathrm{N}$, nitrogen; $\mathrm{C}$, carbon; $\mathrm{HCO}_{3}$, bicarbonate; $A$, ratio of total dissolved solids to specific conductance; $<$, less than]

\begin{tabular}{|c|c|c|c|c|c|c|c|}
\hline \multirow[b]{2}{*}{ Constituent } & \multicolumn{7}{|c|}{ Hydrogeologic group } \\
\hline & $A^{l}$ & B & $\mathbf{B 1}^{1}$ & $\mathbf{c}^{1}$ & D & E & $\mathbf{F}^{1}$ \\
\hline $\mathrm{pH}$, standard units & 5.9 & 7.5 & 7.4 & 7.6 & 6.3 & 6.6 & 5.8 \\
\hline Specific conductance, $\mu \mathrm{S} / \mathrm{cm}$ & 35 & 440 & 875 & 432 & 135 & 185 & 139 \\
\hline Dissolved oxygen, $\mathrm{mg} / \mathrm{L}$ & 6.4 & 2.6 & 1.3 & 3.0 & 4.9 & 2.9 & .4 \\
\hline Alkalinity, $\mathrm{mg} / \mathrm{L}$, as $\mathrm{CaCO}_{3}$ & 13 & 189 & 219 & 138 & 64 & 98 & 59 \\
\hline Temperature, ${ }^{\circ} \mathrm{C}$ & 13.0 & 15.5 & 16.5 & 15.2 & 15.0 & 14.0 & 15.5 \\
\hline Hardness, $\mathrm{mg} / \mathrm{L}$, as $\mathrm{CaCO}_{3}$ & 10 & 200 & 380 & 200 & 39 & 72 & 34 \\
\hline Calcium, $\mathrm{mg} / \mathrm{L}$ & 2.3 & 53 & 84 & 48 & 11 & 14 & 6.4 \\
\hline Magnesium, mg/L & 1.1 & 12 & 36 & 16 & 4.1 & 5.3 & 3.6 \\
\hline Sodium, mg/L & 2.2 & 18 & 41 & 18 & 8.3 & 7.1 & 7.4 \\
\hline Potassium, mg/L & 1.8 & .70 & .90 & .70 & 1.1 & 1.9 & 4.9 \\
\hline Bicarbonate, $\mathrm{mg} / \mathrm{L}$, as $\mathrm{HCO}_{3}$ & 17 & 235 & 267 & 171 & 79 & 102 & 72 \\
\hline Sulfate, $\mathrm{mg} / \mathrm{L}$ & 1.7 & 14 & 260 & 35 & 6.5 & 4.5 & 5.5 \\
\hline Chloride, $\mathrm{mg} / \mathrm{L}$ & 1.8 & 13 & 18 & 12 & 3.1 & 4.1 & 3.2 \\
\hline Fluoride, $\mathrm{mg} / \mathrm{L}$ & $<.10$ & .10 & .20 & $<.10$ & $<.10$ & $<.10$ & .20 \\
\hline Silica, $\mathrm{mg} / \mathrm{L}$ & 12 & 26 & 28 & 28 & 31 & 24 & 36 \\
\hline $\begin{array}{l}\text { Total dissolved solids, } \\
\text { sum of constituents, mg/L }\end{array}$ & 33 & 273 & 631 & 286 & 106 & 126 & 122 \\
\hline$A$ & .91 & .65 & .71 & .68 & .74 & .75 & .79 \\
\hline Nitrite + Nitrate, $\mathrm{mg} / \mathrm{L}$, as $\mathrm{N}$ & .200 & .750 & .600 & .630 & .100 & .100 & $<.050$ \\
\hline Phosphorus, mg/L & .030 & .010 & $<.010$ & .020 & .020 & .030 & .300 \\
\hline Aluminum, $\mu \mathrm{g} / \mathrm{L}$ & $<10$ & $<10$ & $<10$ & $<10$ & $<10$ & $<10$ & $<10$ \\
\hline Barium, $\mu \mathrm{g} / \mathrm{L}$ & 24 & 160 & 87 & 60 & 8 & 43 & 45 \\
\hline Iron, $\mu \mathrm{g} / \mathrm{L}$ & 10 & 6 & 8 & 7 & 8 & 25 & 2,200 \\
\hline Manganese, $\mu \mathrm{g} / \mathrm{L}$ & 3 & $<1$ & 3 & 2 & 6 & 27 & 110 \\
\hline Strontium, $\mu \mathrm{g} / \mathrm{L}$ & 28 & 260 & 2,200 & 145 & 46 & 55 & 50 \\
\hline Radon-222, pCi/L & 1,300 & 1,200 & 2,000 & 870 & 3,100 & 2,400 & 350 \\
\hline Dissolved organic carbon, $\mathrm{mg} / \mathrm{L}$, as $\mathrm{C}$ & .4 & .5 & .6 & .4 & .4 & .3 & .5 \\
\hline Arsenic, $\mu \mathrm{g} / \mathrm{L}$ & $<1$ & $<1$ & 4 & 2 & $<1$ & $<1$ & $<1$ \\
\hline Beryllium, $\mu \mathrm{g} / \mathrm{L}$ & $<.5$ & $<.5$ & $<.5$ & $<.5$ & $<.5$ & $<.5$ & $<.5$ \\
\hline Cadmium, $\mu \mathrm{g} / \mathrm{L}$ & $<1$ & $<1$ & 1 & $<1$ & $<1$ & $<1$ & $<1$ \\
\hline Chromium, $\mu \mathrm{g} / \mathrm{L}$ & $<5$ & $<5$ & $<5$ & $<5$ & $<5$ & $<5$ & $<5$ \\
\hline Cobalt, $\mu \mathrm{g} / \mathrm{L}$ & $<3$ & $<3$ & $<3$ & $<3$ & $<3$ & $<3$ & $<3$ \\
\hline Copper, $\mu \mathrm{g} / \mathrm{L}$ & $<10$ & $<10$ & $<10$ & $<10$ & $<10$ & $<10$ & $<10$ \\
\hline Lead, $\mu \mathrm{g} / \mathrm{L}$ & $<10$ & $<10$ & $<10$ & $<10$ & $<10$ & $<10$ & $<10$ \\
\hline Lithium, $\mu \mathrm{g} / \mathrm{L}$ & $<4$ & 19 & 37 & 14 & $<4$ & $<4$ & 6 \\
\hline Mercury, $\mu \mathrm{g} / \mathrm{L}$ & $<.1$ & $<.1$ & $<.1$ & $<.1$ & $<.1$ & $<.1$ & $<.1$ \\
\hline Molybdenum, $\mu \mathrm{g} / \mathrm{L}$ & $<10$ & $<10$ & $<10$ & $<10$ & $<10$ & $<10$ & $<10$ \\
\hline Nickel, $\mu \mathrm{g} / \mathrm{L}$ & $<10$ & $<10$ & $<10$ & $<10$ & $<10$ & $<10$ & $<10$ \\
\hline Silver, $\mu \mathrm{g} / \mathrm{L}$ & $<1$ & $<1$ & $<1$ & $<1$ & $<1$ & $<1$ & $<1$ \\
\hline Vanadium, $\mu \mathrm{g} / \mathrm{L}$ & $<6$ & 8 & 22 & $<6$ & $<6$ & $<6$ & $<6$ \\
\hline Zinc, $\mu \mathrm{g} / \mathrm{L}$ & 54 & 8 & 4 & 18 & 9 & 32 & 27 \\
\hline
\end{tabular}

${ }^{1}$ Median values calculated from limited number of analyses. Values for hydrogeologic groups A, B1, C, and F are based on 9, 9, 8, and 5 analyses, respectively. 
the laboratory and elapsed time since the sample was collected can allow for degassing and precipitation, which can alter the sample. Boxplots showing summaries of the distribution for each field property in ground water from rocks of the different hydrogeologic groups are presented in figure 8 .

\section{$\mathrm{pH}$}

The $\mathrm{pH}$ of water is defined as the negative base10 logarithm of the hydrogen-ion activity in moles per liter. Water with $\mathrm{pH}$ less than 7.0 is acidic and water with $\mathrm{pH}$ greater than 7.0 is basic (alkaline). If $\mathrm{pH}$ is 7.0 , then the water is considered neutral. Most natural waters are buffered by the presence of carbon dioxide $\left(\mathrm{CO}_{2}\right)$ in the form of carbonic acid $\left(\mathrm{H}_{2} \mathrm{CO}_{3}\right)$, bicarbonate $\left(\mathrm{HCO}_{3}{ }^{-}\right)$and carbonate $\left(\mathrm{CO}_{3}{ }^{2-}\right)$ ions ( $\mathrm{Hem}, 1960$, p. 35). The $\mathrm{pH}$ of ground water in Prince William County ranges from 5.1 to $9.5 \mathrm{mg} / \mathrm{L}$ (fig. 8) with a median value of 7.2. The $\mathrm{pH}$ in 23 ( 26 percent) of the 88 water samples from wells was less than the lower USEPA SMCL of 6.5, and the upper USEPA SMCL of 8.5 was exceeded in only 2 (about 2 percent) of the 88 samples (fig. 9). Ground water tends to be more acidic in hydrogeologic groups $\mathrm{A}$ and $\mathrm{F}$ than in the other groups. The $\mathrm{pH}$ values for water from hydrogeologic groups B, B1, and C generally are higher (basic) than those in the other groups and within the lower and upper SMCL (fig. 9). Ground water from hydrogeologic groups $\mathrm{D}$ and $\mathrm{E}$ in the Piedmont predominantly is acidic with median values of 6.3 and 6.6 , respectively. Acidic ground water may be the result of the lack of calcium carbonate in the rocks to form carbon dioxide, the biochemical oxidation of organic material, or the dissolution of pyrite $\left(\mathrm{FeS}_{2}\right)$.

The combination of acidic water, low alkalinity and total dissolved solids concentrations, and high dissolved oxygen concentrations are indications that waters from hydrogeologic groups $\mathrm{A}, \mathrm{D}$, and $\mathrm{E}$ are aggressive and will tend to corrode pipes and plumbing fixtures, possibly leaving blue or green stains.

Water from the other groups have the opposite characteristics and will tend to form deposits in and on pipes and plumbing fixtures.

\section{Specific Conductance}

Specific conductance is a measure of the ability of water to conduct an electrical current and can provide an indication of ion concentration of the water. Generally, the specific conductance of water increases as the concentration of charged ionic species increases
(Hem, 1985, p. 66). The specific conductance of ground water in Prince William County ranges from 10 to $1,500 \mu \mathrm{S} / \mathrm{cm}$ at $25^{\circ} \mathrm{C}$ (fig. 8) with a median value of $300 \mu \mathrm{S} / \mathrm{cm}$. Specific conductance is extremely low (usually less than $100 \mu \mathrm{S} / \mathrm{cm}$ ) for hydrogeologic group $\mathrm{A}$ and high for groups B, B1, and C. Groups D, E, and $F$ have values for specific conductance that occur between the two extremes. The relation of specific conductance to chloride, hardness, sulfate, and total dissolved solids concentrations of ground water in the county is illustrated in fig 10. Positive relations between specific conductance and the other constituents is evident within the county (fig. 10); however, any relation between specific conductance and the extremely low chloride concentration is masked by the effects of the other constituents.

Specific conductance can be used to approximate total dissolved solids concentration in dilute solution by multiplying the conductance determination by factor $A$, which simply is the ratio of total dissolved solids concentration to specific conductance (Hem, 1985, p. 67). The values for $A$ in the county range from 0.52 to 2.8 with a median value of 0.71 . The values for $A$ that exceed 1.0 are associated with the extremely dilute waters of hydrogeologic groups A, D, $\mathrm{E}$, and $\mathrm{F}$ that have specific conductance determinations less than $30 \mu \mathrm{S} / \mathrm{cm}$. The respective median values for $A$ presented in table 5 can be used to estimate total dissolved solids concentration in samples collected within the area underlain by a particular hydrogeologic group.

\section{Dissolved Oxygen}

Dissolved oxygen enters the ground-water system by way of precipitation. The mean annual temperature in Prince William County is $13.3^{\circ} \mathrm{C}$ (Owenby and Ezell, 1992). Therefore, the dissolved oxygen saturation concentration of precipitation is assumed to be about $10 \mathrm{mg} / \mathrm{L}$. As ground water moves through the flow system, oxygen is depleted by biochemical and chemical reactions involving organic material and oxidizable minerals (Hem, 1985, p. 155). The concentration of dissolved oxygen in ground water in the county ranges from 0 to $8.7 \mathrm{mg} / \mathrm{L}$ (fig. 8 ) with a median concentration of $3.6 \mathrm{mg} / \mathrm{L}$. The dissolved oxygen concentration tends to be high in the fractured-rock systems of Prince William County, especially in hydrogeologic group $\mathrm{A}$. The low concentration detected in ground water from wells in hydrogeologic group F may be attributed to the abundance of organic material 
NUMBER OF ANALYSES
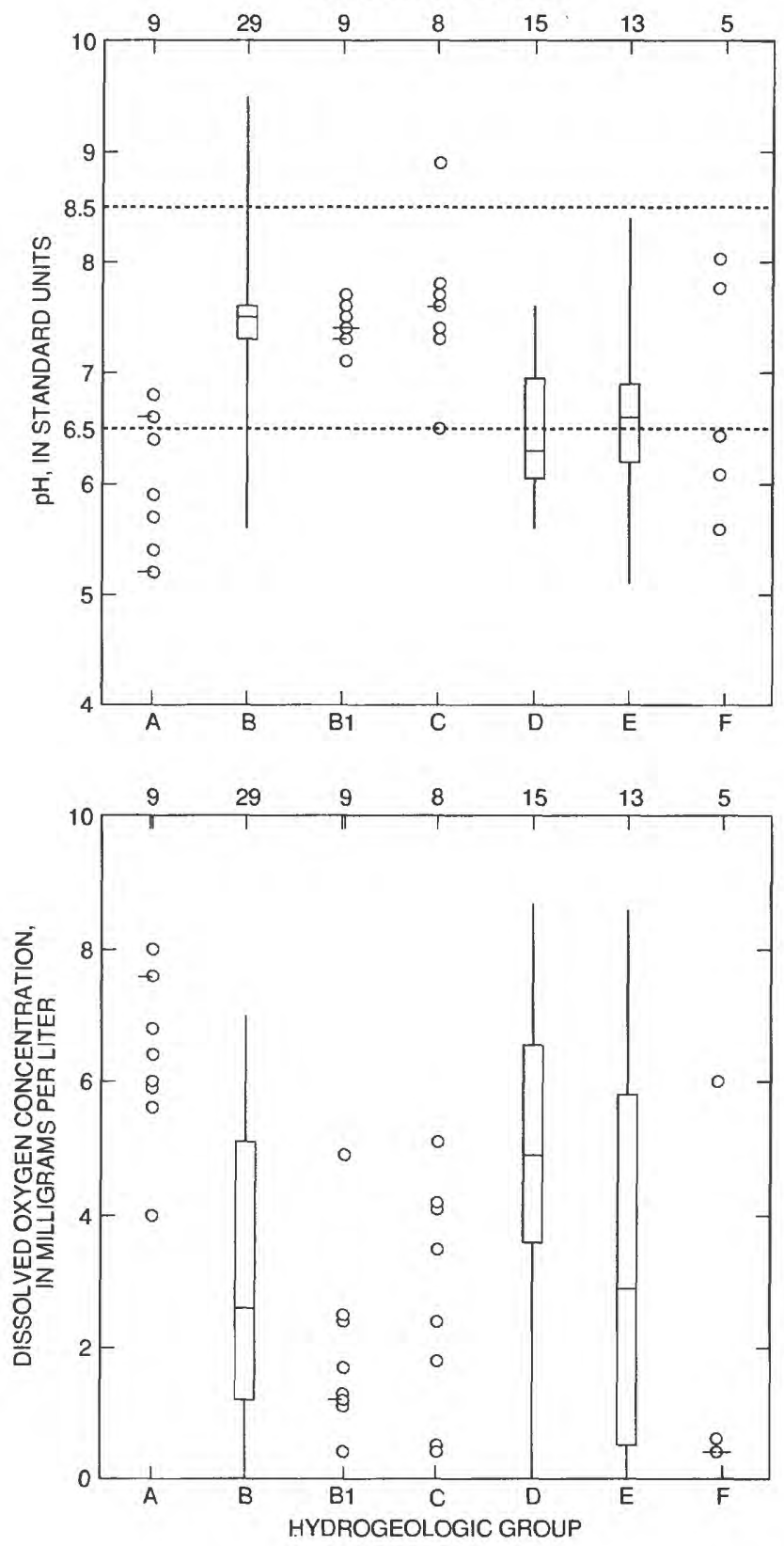

NUMBER OF ANALYSES
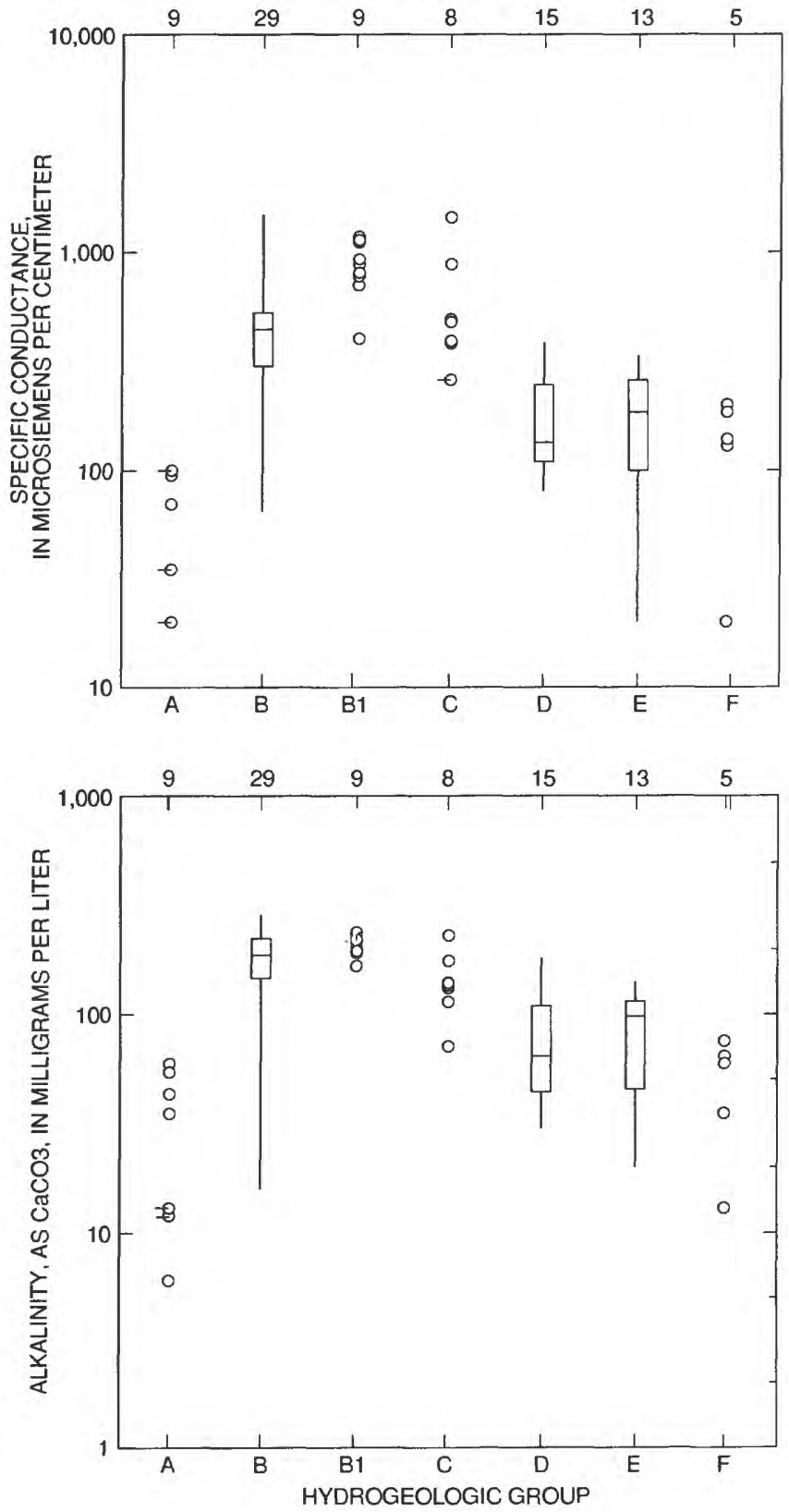

EXPLANATION

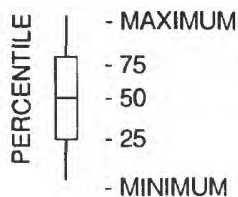

U.S. ENVIRONMENTAL PROTECTION AGENCY SECONDARY MAXIMUM CONTAMINANT LEVEL (SMCL) OR VIRGINIA GROUND-WATER STANDARD (VGWS)

CONCENTRATION OF INDIVIDUAL ANAL YSIS-All data are plotted when total number of analyses is less than 12. Bar refers to additional analyses at the same concentration

Figure 8. Summaries of field properties for water samples from wells in Prince William County, Virginia. 


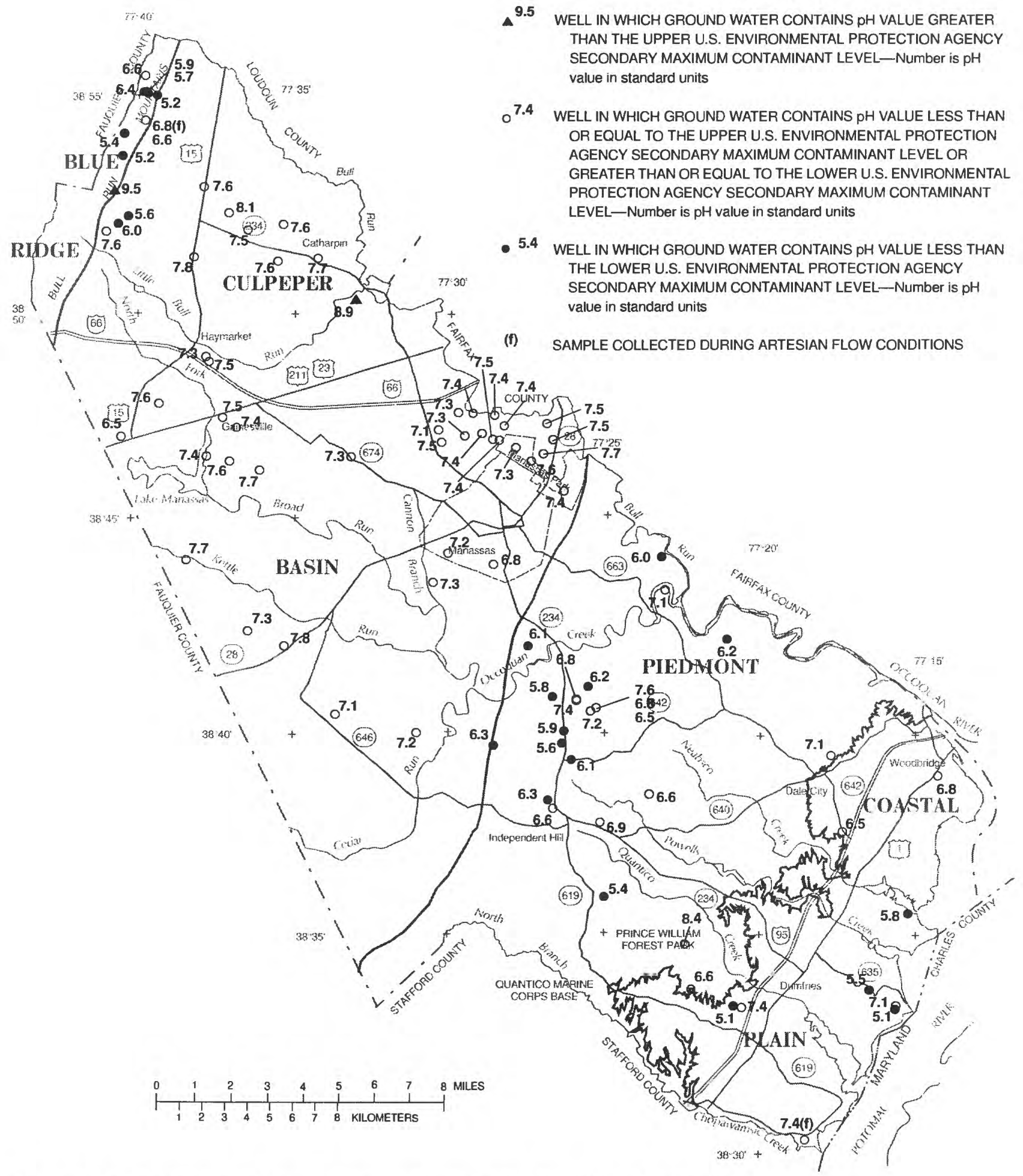

Figure 9. Distribution of $\mathrm{pH}$ for water samples from wells in Prince William County, Virginia. 


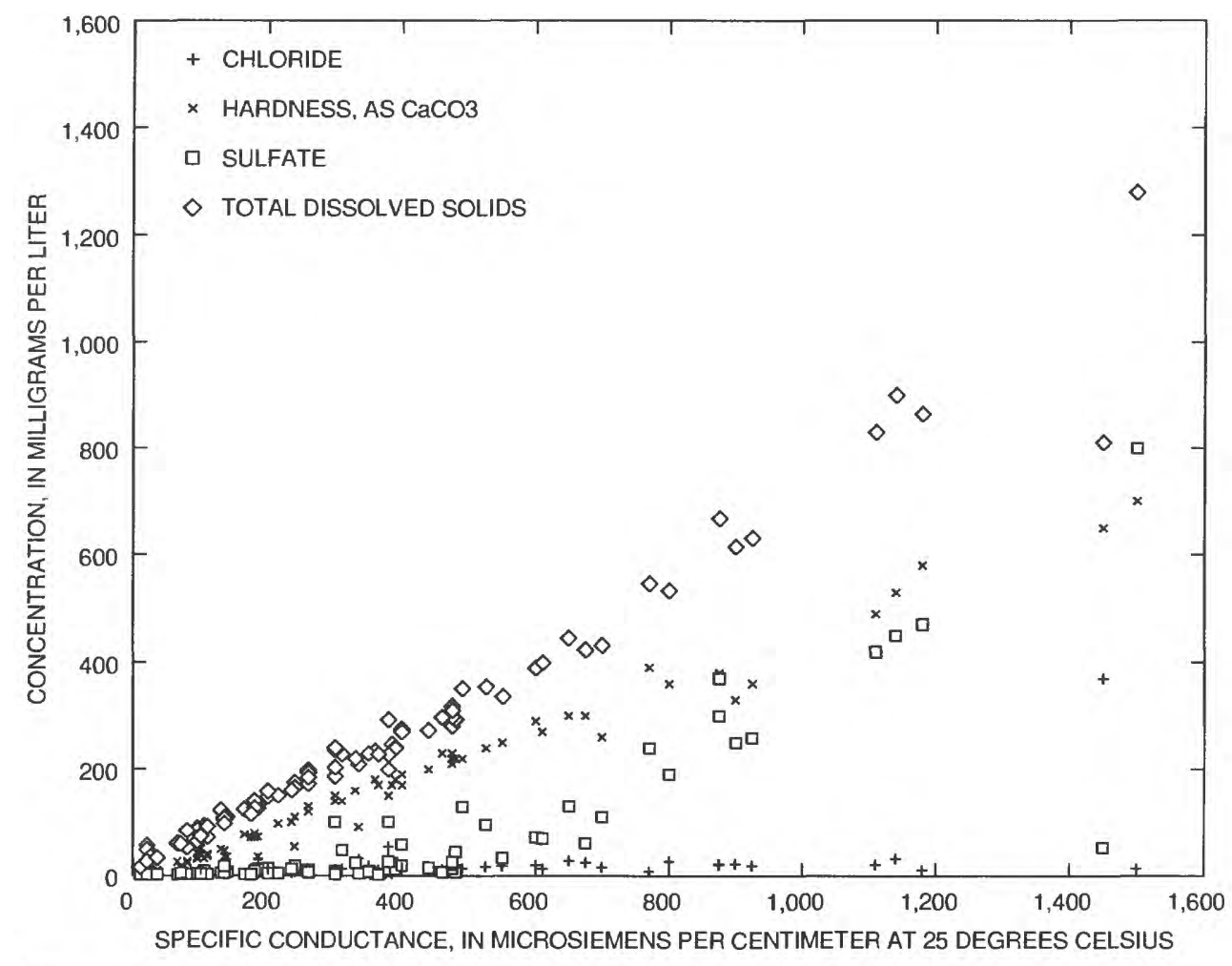

Figure 10. Relation of specific conductance to chloride, hardness, sulfate, and total dissolved solids concentrations of ground water in Prince William County, Virginia.

(lignite) and oxidizable minerals, and the long residence times of ground water.

Generally, three trends in the concentration of dissolved oxygen in ground water are evident within the county. First, dissolved oxygen concentration tends to decrease with increasing depths of the water zones encountered; however, measurable dissolved oxygen concentration occurs in wells in the Culpeper Basin that produce from water zones greater than 500 $\mathrm{ft}$ below land surface. Secondly, low-yielding wells in the fractured-rock systems tend to have low dissolved oxygen concentration possibly related to longer residence times of ground water, which increases the time available for the water to react with the rocks. Thirdly, dissolved oxygen concentration tends to be highest on hilltops and become progressively lower toward the valleys. This apparent relation between dissolved oxygen concentration and topographic setting is related simply to the consumption of oxygen as the ground water flows from recharge to discharge areas.

\section{Alkalinity}

Alkalinity is defined as the capacity of water to react with and neutralize acid and is reported usually in terms of an equivalent amount of calcium carbonate $\left(\mathrm{CaCO}_{3}\right)$. Alkalinity is predominantly produced by dissolved carbon dioxide species, bicarbonate and carbonate (Hem, 1985, p. 106). The alkalinity of ground water in Prince William County ranges from 6 to $290 \mathrm{mg} / \mathrm{L}$ (fig. 8) with a median concentration of 123 $\mathrm{mg} / \mathrm{L}$. Alkalinity of ground water in the county is produced primarily by bicarbonate. Alkalinity and bicarbonate concentrations are much higher in the ground water from the hydrogeologic groups of the Culpeper Basin (hydrogeologic groups B, Bl, and C) than those in the other groups. Calcite cement and carbonate rocks are present in the Culpeper Basin (Posner and Zenone, 1983; Lee and Froelich, 1989) and are the reason for the high alkalinity and bicarbonate concentrations within the basin.

\section{Hardness}

Hardness in this report is defined as the calculated sum of the concentrations of calcium and magnesium, and it is usually reported in terms of an equivalent concentration of $\mathrm{CaCO}_{3}$. Excessive hardness (greater than $100 \mathrm{mg} / \mathrm{L}$, as $\mathrm{CaCO}_{3}$ ) can affect the cleansing properties of soap ("soap curd"), form 
incrustations on the inside of pipes and plumbing fixtures, and make laundry dingy and gray. The reader may be familiar with the terms "hard" and "soft" water, which are commonly used to describe the hardness of natural waters. A system developed by Durfor and Becker $(1964$, p. 27) to classify hardness is listed in table 6. The hardness of ground water in Prince William County ranges from 0 to $700 \mathrm{mg} / \mathrm{L}$ (fig. 11) with a median concentration of $120 \mathrm{mg} / \mathrm{L}$. The abundance of calcium and magnesium in the Culpeper Basin explains the high hardness of ground water in the rocks of hydrogeologic groups B, B1, and C. The low hardness values in the Culpeper Basin are associated with formations in which silica rather than calcite is the cementing mineral. Generally, ground water is soft in the rocks of hydrogeologic groups $\mathrm{A}$ and F; soft to very hard in hydrogeologic groups $B$ and $C$; soft to moderately hard in hydrogeologic groups $\mathrm{D}$ and $\mathrm{E}$; and very hard in hydrogeologic group B1.

Table 6. Classification of the hardness of water

[modified from Durfor and Becker (1964, p. 27); mg/L, milligrams per liter; $\mathrm{CaCO}_{3}$, calcium carbonate; >, more than]

\begin{tabular}{cl}
\hline $\begin{array}{l}\text { Hardness range } \\
\left(\mathrm{mg} / \mathrm{L}, \text { as } \mathrm{CaCO}_{3}\right)\end{array}$ & Description \\
\hline $0-60$ & Soft \\
$61-120$ & Moderately hard \\
$121-180$ & Hard \\
$>180$ & Very hard \\
\hline
\end{tabular}

\section{Selected Dissolved Inorganic Constituents}

The water samples collected from wells in Prince William County were analyzed for common ions to determine the chemical composition of ground water in the county. The abundance of the different ionic species found in ground water varies between and within the different hydrogeologic groups. For the most part, calcium is the predominant cation ( 49 percent of the samples) and bicarbonate is the predominant anion ( 81 percent) in ground water in the county. Bicarbonate is not discussed in this section because the previous discussion of the occurrence and distribution of alkalinity also applies to bicarbonate. A substantial amount (44 percent) of the water samples from wells in the county indicate that no cation is predominant. Modified Stiff diagrams of water-quality analy- ses from wells representative of water from the different hydrogeologic groups show the variability of ground-water quality throughout the county (fig. 12). Boxplots showing summaries of selected inorganic constituents in ground water from rocks of the different hydrogeologic groups are presented in figure 11 .

\section{Calcium}

Calcium is an essential element for plants and animals and an important component of many rock minerals and natural waters. Calcium occurs only in the divalent oxidation state $\left(\mathrm{Ca}^{2+}\right)$. The major sources of calcium are (1) igneous and metamorphic rock minerals - pyroxene, amphibole, and feldspars; (2) carbonate rocks-limestone $\left(\mathrm{CaCO}_{3}\right)$ and dolomite $\left(\mathrm{CaMg}\left(\mathrm{CO}_{3}\right)_{2}\right)$; (3) calcite $\left(\mathrm{CaCO}_{3}\right)$ as cement in pore spaces of sedimentary rocks and as fill along veins and fractures of all types of rocks; (4) evaporites - gypsum $\left(\mathrm{CaSO}_{4} \cdot 2 \mathrm{H}_{2} \mathrm{O}\right)$ and anhydrite $\left(\mathrm{CaSO}_{4}\right)$; and (5) clay minerals. Negatively charged mineral surfaces in soils commonly adsorb calcium ions. The equilibria of carbonates is the major process affecting the solubility and occurrence of calcium in ground water, but ion exchange with other cations can affect the relative abundance of calcium in solution (Hem, 1985, p. 8990). The concentration of calcium in ground water in Prince William County ranges from 0.07 to $240 \mathrm{mg} / \mathrm{L}$ (fig. 11) with a median concentration of $34 \mathrm{mg} / \mathrm{L}$. Calcium concentration tends to be highest in ground water of the Culpeper Basin (hydrogeologic groups B, B1, and $C$ ) because of the abundance of carbonate rock, calcite cement, and gypsum. Low concentration of calcium in the Culpeper Basin, however, is associated with the basalts and the sedimentary rock cemented by silica $\left(\mathrm{SiO}_{2}\right)$. The other hydrogeologic groups include rocks that are fairly resistant to weathering so that calcium concentration in ground water tends to be low when compared to the Culpeper Basin. The quartzite and phyllite of hydrogeologic group A have sparse amounts of carbonate material and feldspars available to contribute calcium to the ground water. Cation exchange between calcium and either magnesium, sodium, or potassium in the overburden, sediments, and rocks may explain the low concentrations present in the ground water of hydrogeologic groups D, E, and $\mathrm{F}$.

\section{Magnesium}

Magnesium is another element essential in the growth and nutrition of plants and animals. 

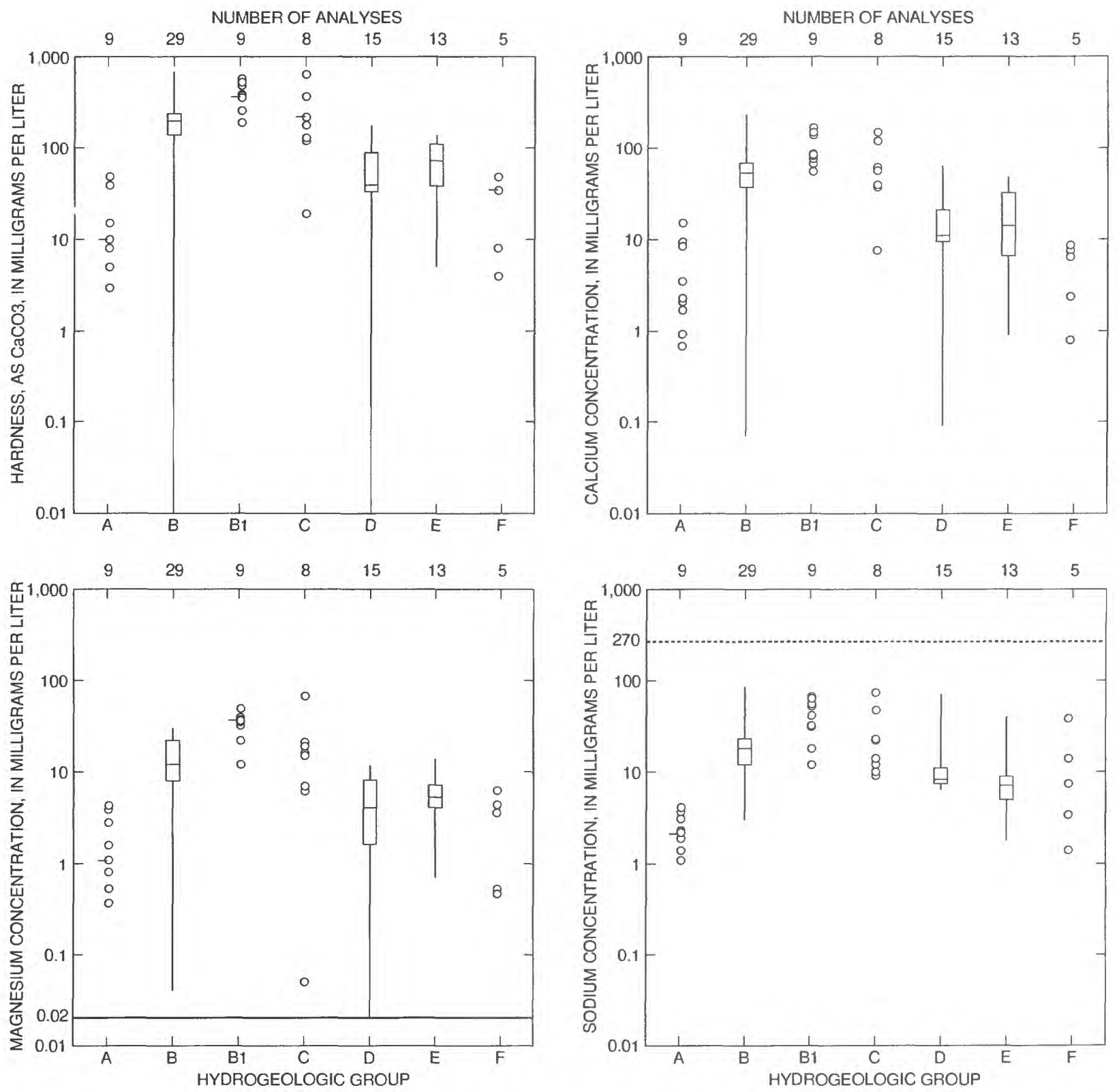

\section{EXPLANATION}
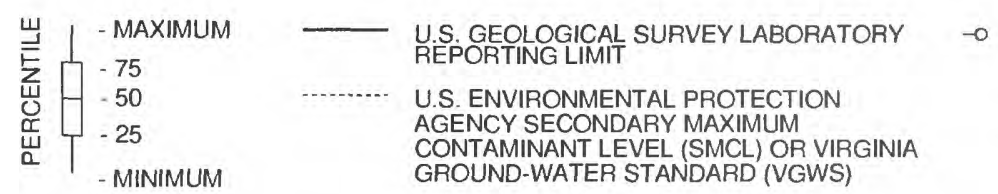

CONCENTRATION OF INDIVIDUAL ANALYSIS-AII data are plotted when total number of analyses is less than 12. Bar refers to additional analyses at the same concentration.

Figure 11. Summaries of analyses of hardness and selected inorganic constituents in ground water in Prince William County, Virginia. 
NUMBER OF ANALYSES
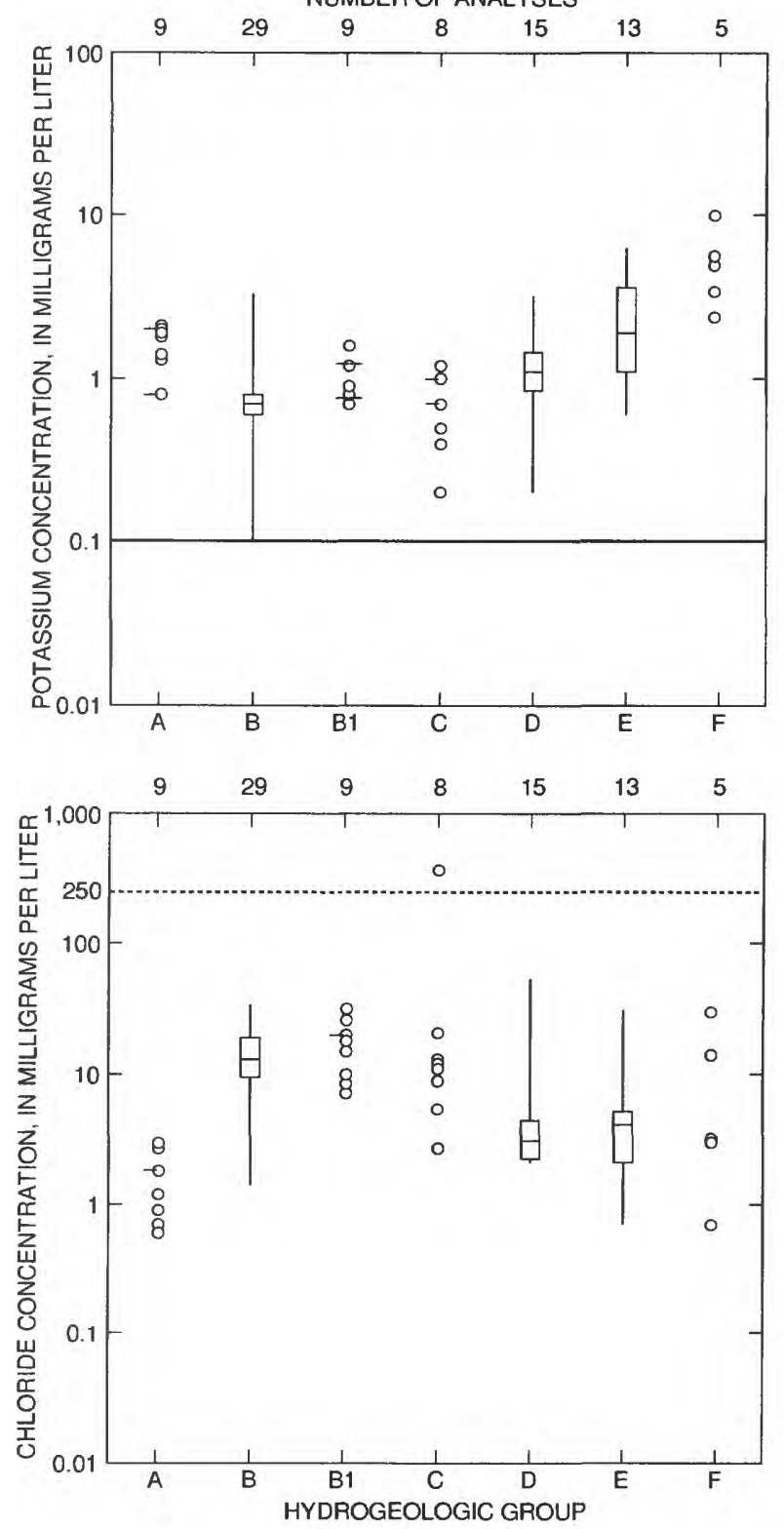

NUMBER OF ANALYSES
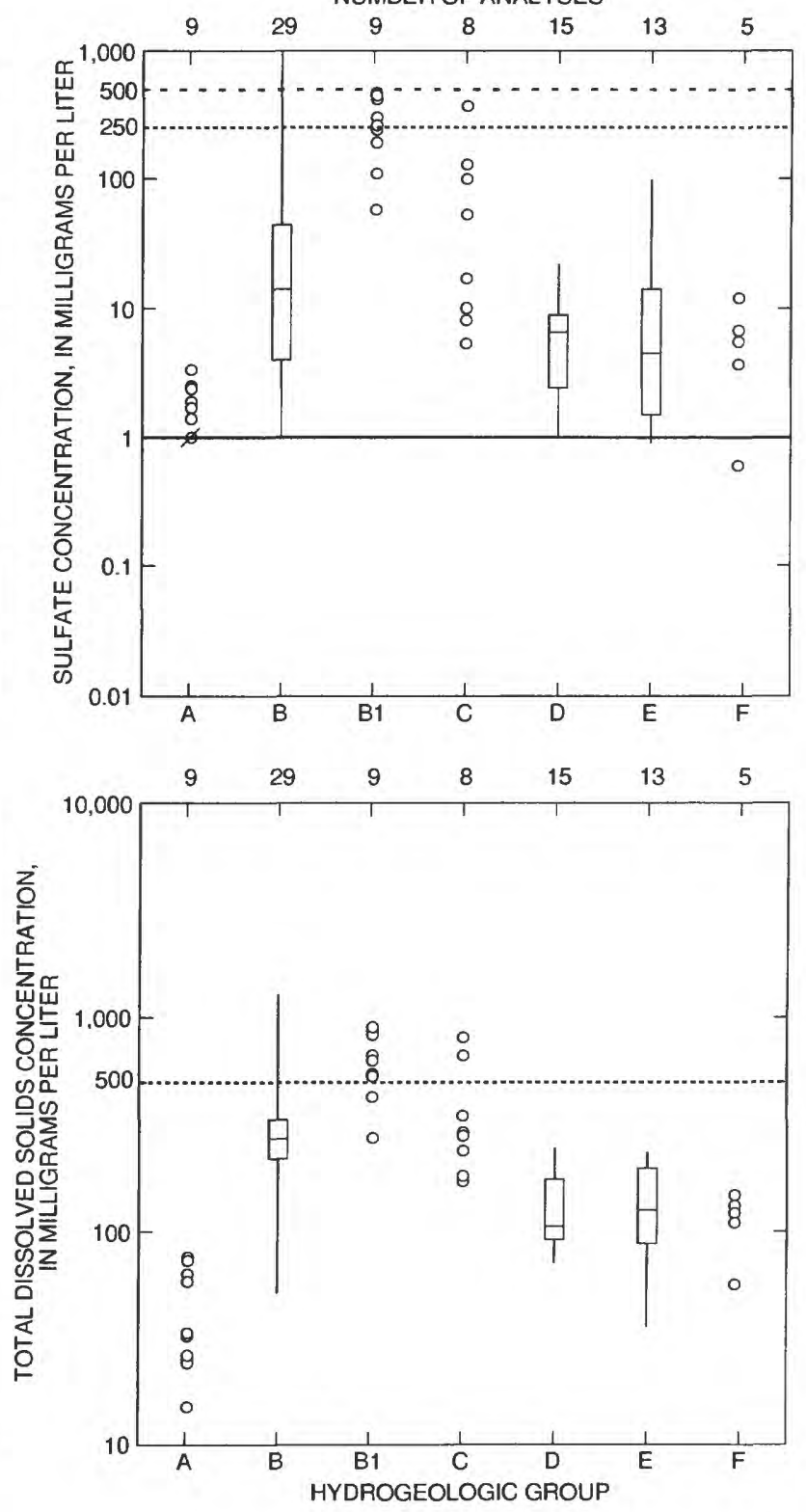

EXPLANATION
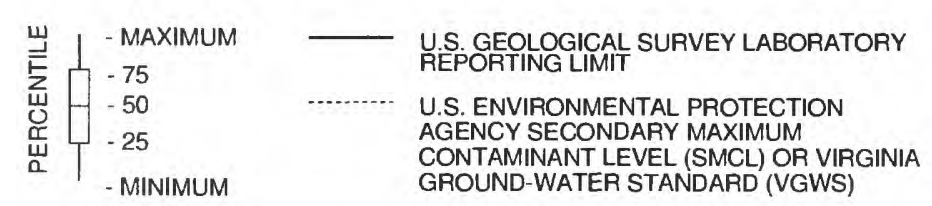
- - - U.S. ENVIRONMENTAL PROTECTION AGENCY MAXIMUM CONTAMINANT LEVEL (MCL)
-O CONCENTRATION OF INDIVIDUAL ANALYSIS-AII data are plotted when total number of analyses is less than 12 Bar refers to additional analyses at the same concentration.

Figure 11. Summaries of analyses of hardness and selected inorganic constituents in ground water in Prince William County, Virginia - Continued. 


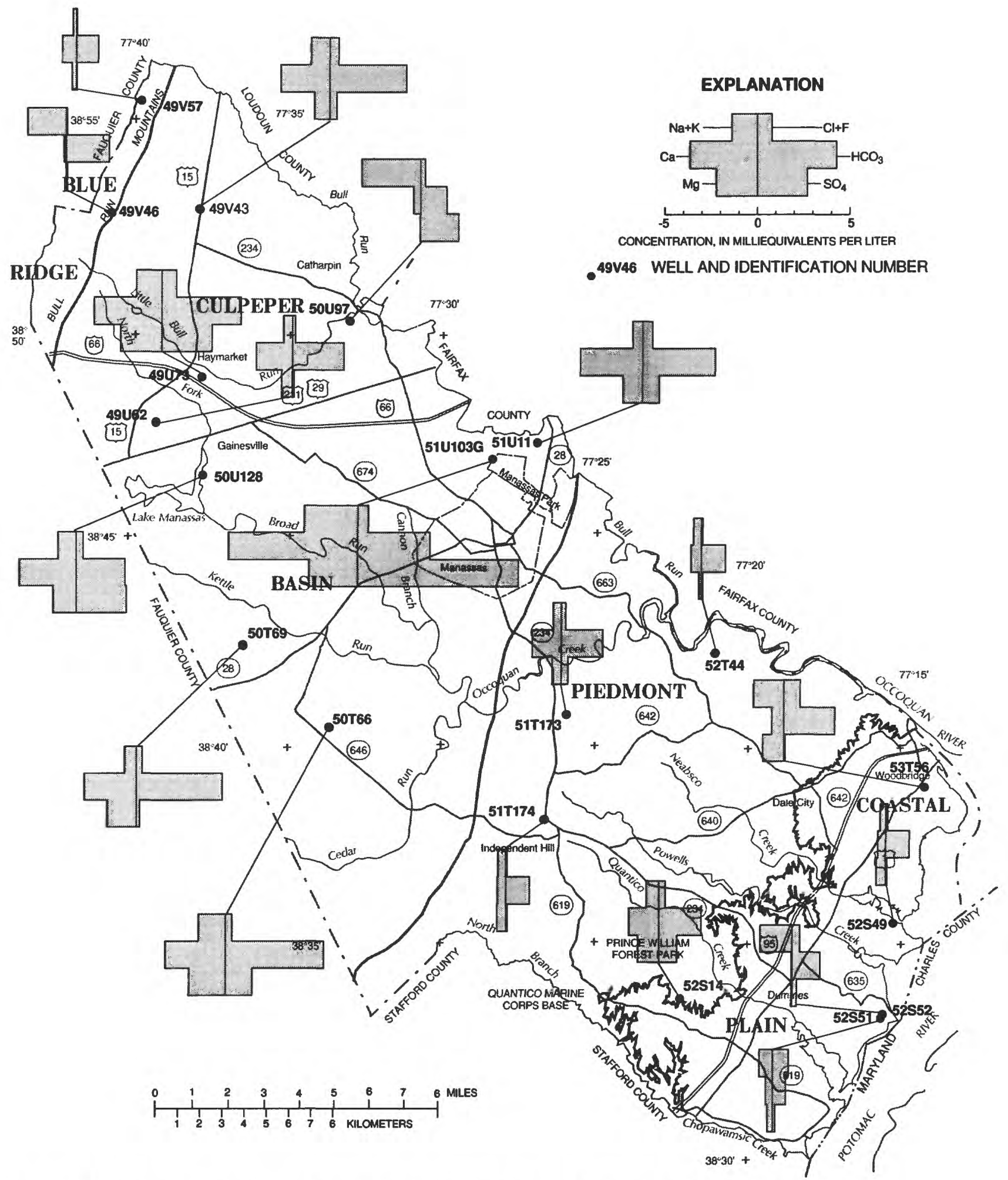

Figure 12. Modified Stiff diagrams illustrating ground-water quality in Prince William County, Virginia. 
Magnesium also occurs in the divalent oxidation state $\left(\mathrm{Mg}^{2+}\right)$, but has different geochemical properties from calcium because the size of the magnesium ion is smaller than the calcium ion. The major sources of magnesium are (1) igneous and metamorphic rock minerals - olivine, pyroxene, amphibole, and mica; (2) alteration minerals - chlorite and serpentine; and (3) carbonate rocks. High concentrations of magnesium in ground water can have a laxative effect on new users of such water (Todd, 1980, p. 273). The concentration of magnesium in ground water in Prince William County ranges from below the USGS reporting limit of 0.02 to $67 \mathrm{mg} / \mathrm{L}$ (fig. 11) with a median concentration of $7.9 \mathrm{mg} / \mathrm{L}$. The distribution of magnesium concentration is similar to the distribution of calcium, but magnesium concentration tends to be slightly lower than those of calcium.

\section{Sodium}

Sodium occurs in ground water in the monovalent oxidation state $\left(\mathrm{Na}^{+}\right)$. Major sources of sodium are (1) feldspars, (2) evaporites, (3) clay minerals, (4) connate water, and (5) anthropogenic activities-road salt. Redox (reduction-oxidation) processes and precipitation reactions generally do not involve sodium; therefore, sodium tends to remain in solution. Cation exchange and adsorption on clay minerals are the geochemical processes controlling sodium concentration in ground water (Hem, 1985, p. 100). Excessive amounts of sodium can be corrosive to plumbing fixtures and boilers (Todd, 1980, p. 273). The concentration of sodium in ground water in Prince William County ranges from 1.1 to $86 \mathrm{mg} / \mathrm{L}$ (fig. 11) with a median concentration of $12 \mathrm{mg} / \mathrm{L}$. No samples exceeded the Virginia Ground-Water Standard (VGWS) (Southeast Virginia Planning District Commission, 1990) of $270 \mathrm{mg} / \mathrm{L}$. Similar to the distributions of calcium and magnesium concentrations, the concentration of sodium tends to be highest in the Culpeper Basin and is related possibly to the presence of evaporites. Ground water from rocks in hydrogeologic group A has extremely low sodium concentrations because of the absence of sodium-bearing minerals.

\section{Potassium}

Potassium is an essential element for plants and animals and exists in the monovalent oxidation state $\left(\mathrm{K}^{+}\right)$. Major sources of potassium are (1) feldspars - orthoclase and microcline, (2) micas, (3) clay minerals, (4) evaporites, and (5) decay of organic material. Generally, potassium occurs in ground water at low concentrations (less than $10 \mathrm{mg} / \mathrm{L}$ ) because potassium does not readily remain in solution and potassium-bearing minerals tend to be resistant to weathering (Hem, 1985, p. 104). The concentration of potassium in ground water in Prince William County ranges from below the USGS reporting limit of 0.1 to $10 \mathrm{mg} / \mathrm{L}$ (fig. 11) with a median concentration of 0.9 $\mathrm{mg} / \mathrm{L}$. Unlike the previously discussed ions, potassium tends to be lowest in the Culpeper Basin (hydrogeologic groups $\mathrm{B}, \mathrm{B} 1$, and $\mathrm{C}$ ). Because the potassium ion has a propensity to be reincorporated into solid matter, the abundance of fractures in the rocks of the Culpeper Basin may increase the availability of potential adsorption sites for the potassium ion. Feldspars and micas are abundant in the Piedmont rocks (hydrogeologic groups D and E), which may explain the high potassium concentration. The highest concentration of potassium occur in ground water of hydrogeologic group F; possibly in response to the long ground-water residence times.

\section{Sulfate}

Sulfate $\left(\mathrm{SO}_{4}{ }^{2-}\right)$ is the oxidized form of elemental sulfur, and hydrogen ions are usually produced during this oxidation process, which can lower $\mathrm{pH}$. The major sources of sulfate are (1) metallic sulfidespyrite $\left(\mathrm{FeS}_{2}\right)$, (2) evaporites - gypsum and anhydrite, and (3) anthropogenic activities in the form of atmospheric deposition of by-products from the burning of fossil fuels. The presence and distribution of sulfate in ground water are affected strongly by redox reactions (Hem, 1985, p. 112-116). Elevated concentrations of sulfate (greater than $250 \mathrm{mg} / \mathrm{L}$ ) can make ground water undesirable for certain industrial applications, impart a bitter taste, or be cathartic (Todd, 1980, p. 274). The concentration of sulfate in ground water in Prince William County ranges from below the USGS reporting limit of 1.0 to $800 \mathrm{mg} / \mathrm{L}$ (fig. 11) with a median concentration of $7.8 \mathrm{mg} / \mathrm{L}$. The sulfate concentration in 7 (about 8 percent) of the 88 water samples from wells exceeded the USEPA SMCL of 250 $\mathrm{mg} / \mathrm{L}$, and the USEPA MCL of $500 \mathrm{mg} / \mathrm{L}$ was exceeded in only 1 sample (fig. 13). The highest detected sulfate concentration was in the Culpeper Basin, and all samples that exceeded the two drinkingwater standards were from wells in the Culpeper Basin. Hydrogeologic group B1 tends to have the highest sulfate concentration within the Culpeper 


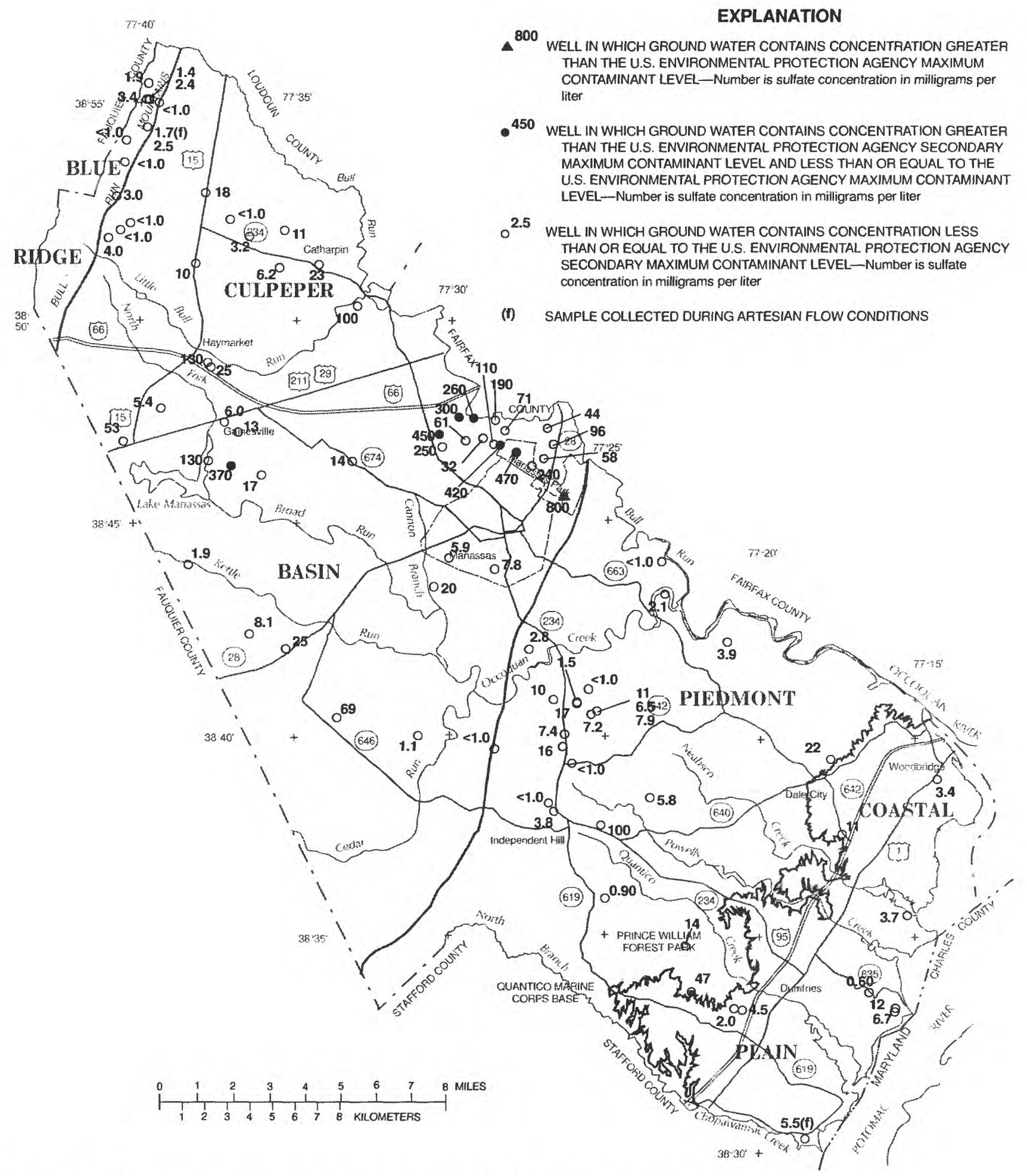

Figure 13. Concentrations of sulfate in ground water in Prince William County, Virginia. 
Basin in response to the abundance of gypsum for dissolution. Water from well $51 \mathrm{U} 4 \mathrm{H}$ had the highest reported sulfate concentration $(800 \mathrm{mg} / \mathrm{L})$ and is included in hydrogeologic group B because the well depth is only $250 \mathrm{ft}$. The high sulfate concentration may be related to local gypsum present at depths shallower than $500 \mathrm{ft}$. Gypsum in rocks of the Culpeper Basin tends to be present at progressively shallower depths toward the south of Prince William County (A.J. Froelich, U.S. Geological Survey, oral commun., 1990). Sulfate concentration in ground water in rocks of the other hydrogeologic groups generally are low and probably related to the presence and availability of pyrite.

\section{Chloride}

Chloride $\left(\mathrm{Cl}^{-}\right)$is readily soluble and is the major form of elemental chlorine present in natural waters. The major sources of chloride are (1) igneous rock minerals - sodalite and apatite, (2) evaporites, (3) connate waters, and (4) anthropogenic activities - road salt and salt-water intrusion induced by ground-water withdrawals in coastal areas. Chloride usually moves through the ground-water system by advective transport and few geochemical processes affect the fate and mobility of this constituent (Hem, 1985, p. 117-118). Excessive chloride concentrations can be corrosive, impart a salty taste to water, and cause physiological damage to plants and animals (Todd, 1980, p. 274). The concentration of chloride in ground water in Prince William County ranges from 0.6 to $370 \mathrm{mg} / \mathrm{L}$ (fig. 11) with a median concentration of $7.2 \mathrm{mg} / \mathrm{L}$. The chloride concentration in only 1 (about 1 percent) of the 88 water samples from wells exceeded the USEPA SMCL of $250 \mathrm{mg} / \mathrm{L}$. The highest reported chloride concentration $(370 \mathrm{mg} / \mathrm{L})$ was in the sample from well 49U75, which is located along the contact between the thermally metamorphosed rocks and the diabase in the Culpeper Basin. Highly mineralized ground water, in response to preferential solution of hydrothermal minerals, tends to be localized in similar geologic settings in the Culpeper Basin (Posner and Zenone, 1983). The distribution of chloride concentration is uniform throughout the county, except that hydrogeologic group A tends to have the lowest chloride concentration.

\section{Total Dissolved Solids}

Total dissolved solids (TDS) is the sum of all mineral constituents dissolved in water. The positive relation between TDS concentration and specific conductance determinations was described earlier. The TDS concentration of ground water in Prince William County ranges from 15 to $1,280 \mathrm{mg} / \mathrm{L}$ (fig. 11) with a median concentration of $198 \mathrm{mg} / \mathrm{L}$. The USEPA SMCL of $500 \mathrm{mg} / \mathrm{L}$ was exceeded in 11 (about 12 percent) of the 88 water samples from wells, all of which are in the Culpeper Basin (fig. 14). The abundance of soluble minerals in the rocks of the Culpeper Basin can explain the high TDS concentration. The sample from well 49U75, which was mentioned in the previous section, has a TDS concentration of $811 \mathrm{mg} / \mathrm{L}$, which is typical for the contact aureole setting described in Posner and Zenone (1983). The rocks in hydrogeologic groups $\mathrm{A}, \mathrm{D}$, and $\mathrm{E}$ are resistant to weathering; therefore, the TDS concentration in ground water tends to be low. The TDS concentration in hydrogeologic group $\mathrm{F}$ is low considering the long ground-water residence times. The absence of soluble minerals in the sediments, however, indicate that geochemical processes, such as ion exchange, redox reactions, or membrane effects by clays, are removing dissolved species from the ground water (Hem, 1985, p. 30). Another possible explanation could be the subsurface discharge of ground water from the consolidated rocks to the west, possibly along faults or fracture zones.

\section{Nutrients}

The water samples collected from wells in Prince William County were analyzed for major nutrients - nitrate and phosphorus. Nutrients are chemical elements that are essential in the nutrition and growth of plants and animals. The major sources of nutrients are (1) atmospheric deposition, (2) minerals, (3) fertilizers, (4) animal wastes, and (5) effluent from sewer and septic systems (Mueller and Helsel, 1996, p. 2). The concentration of nutrients in ground water is usually low; however, elevated concentrations can indicate degradation of ground-water quality by anthropogenic activities. Boxplots showing summaries of the analyses of nutrients in ground water from rocks of the different hydrogeologic groups are shown in figure 15 .

\section{Nitrate}

Nitrate, as reported here, is the concentration of nitrite $\left(\mathrm{NO}_{2}\right)$ plus nitrate $\left(\mathrm{NO}_{3}\right)$ in terms of equivalent elemental nitrogen. The concentration of nitrite 


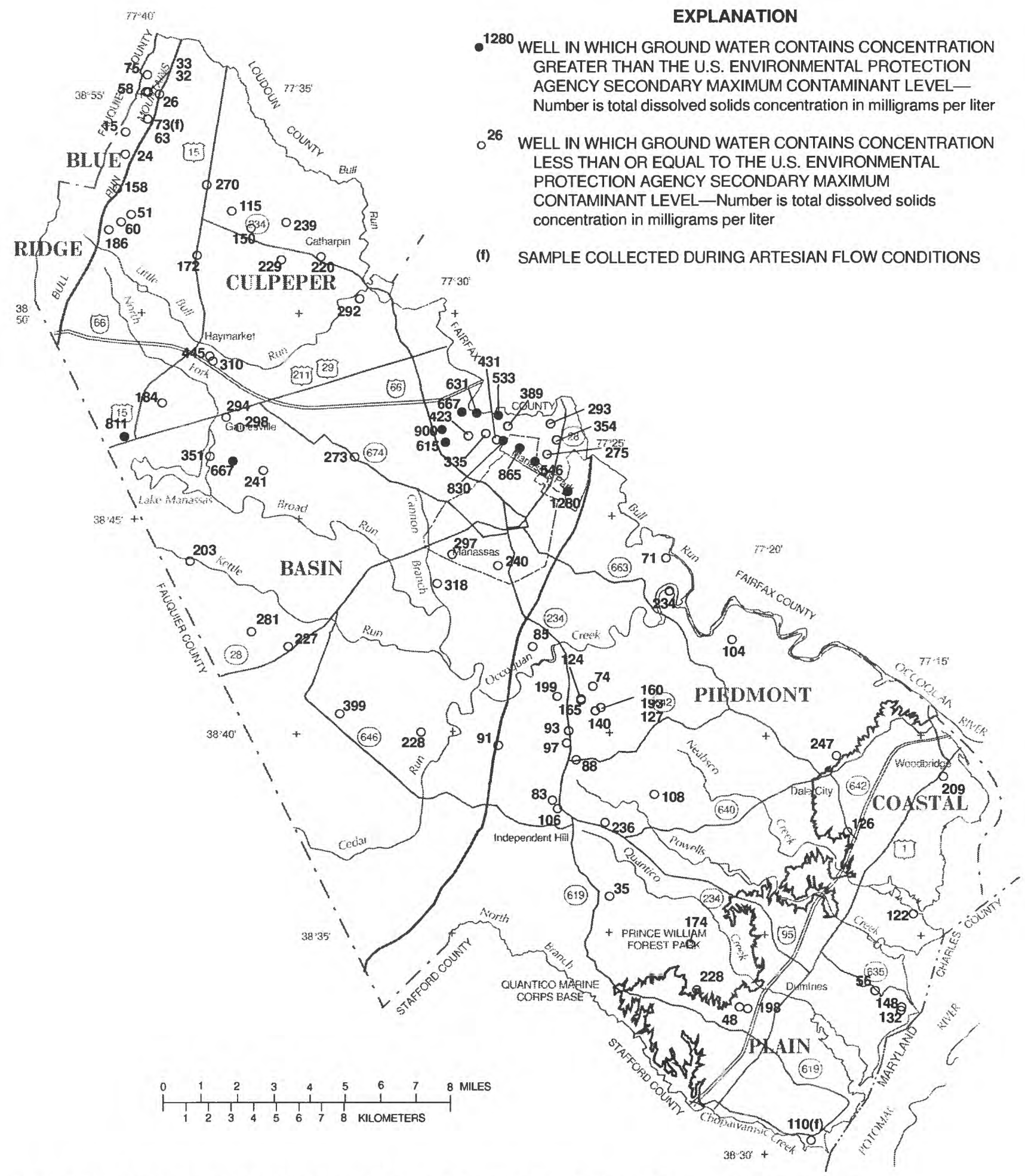

Figure 14. Concentrations of total dissolved solids in ground water in Prince William County, Virginia. 

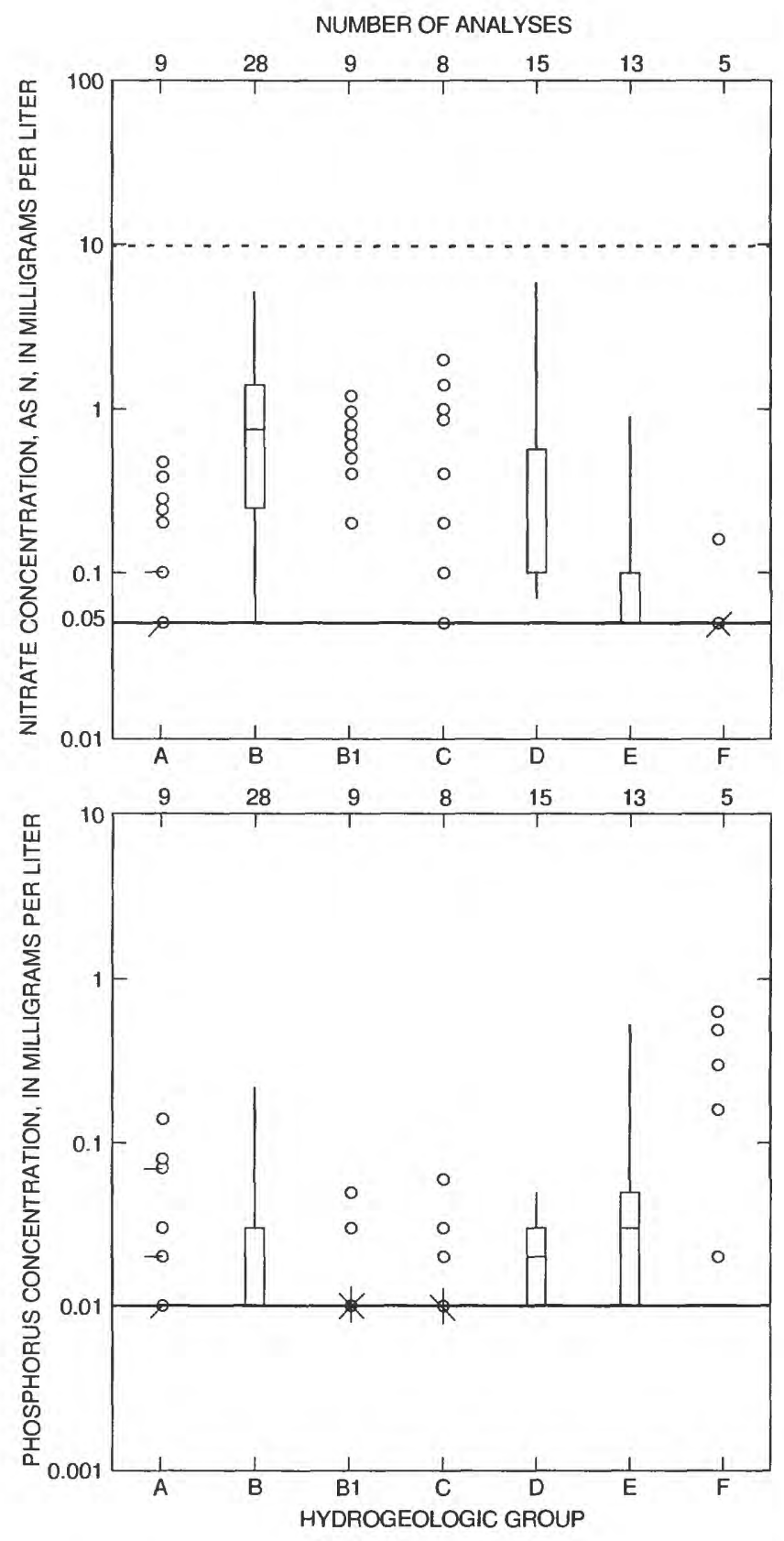

EXPLANATION

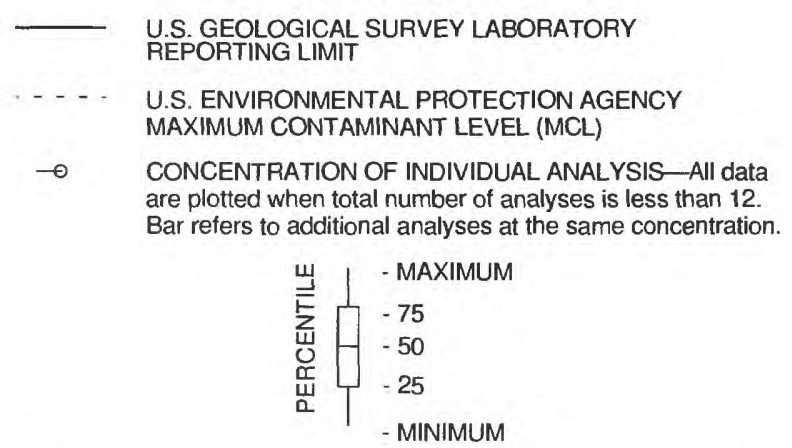

Figure 15. Summaries of analysis of nutrients in ground water in Prince William County, Virginia. usually is negligible in ground water; therefore, concentrations reported for $\mathrm{NO}_{2}+\mathrm{NO}_{3}$ virtually are equal to the concentration of nitrate. Nitrate is extremely soluble, stable over a wide range of environmental conditions, and it is affected by chemical and biological processes (Hem, 1985, p. 124). Methemoglobinemia ("blue baby syndrome") has been attributed to excessive concentrations of nitrate (Mueller and Helsel, 1996, p. 8). The concentration of nitrate in ground water in Prince William County ranges from below the USGS reporting limit of 0.050 to $5.90 \mathrm{mg} / \mathrm{L}$ (fig. 15) with a median value of $0.300 \mathrm{mg} / \mathrm{L}$. No samples exceeded the USEPA MCL of $10 \mathrm{mg} / \mathrm{L}$. Hamilton and others (1991) state that nitrate concentration that is greater than $3.0 \mathrm{mg} / \mathrm{L}$ is the result of human activity. The highest nitrate concentration detected $(5.9 \mathrm{mg} / \mathrm{L})$ was for a sample from well 51T151, which is completed in rocks of hydrogeologic group D just north of Independent Hill; the authors noticed during sample collection that the lawn surrounding the well had recently been fertilized. Well 50T80, which had a sample with a nitrate concentration of $5.2 \mathrm{mg} / \mathrm{L}$, is at a sewage pumping station just south of Manassas.

\section{Phosphorus}

Phosphorus is not as soluble or mobile as nitrate and is derived mostly from minerals in rocks, sediment, and soil (Mueller and Helsel, 1996). Igneous rocks commonly contain phosphorus and apatite is the common mineral source (Hem, 1985, p. 126).

Eutrophication of surface-water bodies by the influx of nutrients tends to be accelerated by the presence of phosphorus (Mueller and Helsel, 1996, p. 9). The concentration of total phosphorus in ground water in Prince William County ranges from below the USGS reporting limit of 0.010 to $0.630 \mathrm{mg} / \mathrm{L}$ (fig. 15) with a median value of $0.020 \mathrm{mg} / \mathrm{L}$. No USEPA MCL or SMCL has been established for phosphorus. The distribution of phosphorus in ground water is uniform throughout the different hydrogeologic groups, but tends to be high in hydrogeologic group F. Synthesis of water-quality data from across the Nation, as part of the USGS National Water-Quality Assessment (NAWQA) Program, indicates that background concentration of total phosphorus in ground water is less than $0.1 \mathrm{mg} / \mathrm{L}$ (Mueller and Helsel, 1996, p. 15). 


\section{Metals and Trace Constituents}

The water samples collected from wells in Prince William County were analyzed for several metals and trace constituents (tables 4 and 5); the concentrations of barium, iron, manganese, strontium, and zinc warrant further discussion. The other metals and trace constituents present at concentrations in ground water that are below or near the USGS reporting limits did not exceed the respective USEPA MCL or SMCL. Additionally, the metals that receive frequent public attention - copper, lead, mercury, and silver-are present at extremely low concentrations in ground water in the county. Existing water systems were used to collect the samples. Project personnel attempted to minimize the contact time of the ground water with the plumbing by collecting the sample as close to the wellhead as possible. In addition, the type of plumbing material visible to project personnel was documented for each well. Boxplots showing summaries of analyses of selected metals in ground water from rocks of the different hydrogeologic groups are shown in figure 16.

\section{Barium}

Barium is an alkaline-earth metal that only exists in ground water in the divalent oxidation state $\left(\mathrm{Ba}^{2+}\right)$. The major sources of barium are barium carbonate $\left(\mathrm{BaCO}_{3}\right)$, barite $\left(\mathrm{BaSO}_{4}\right)$, and freshwater manganese oxide deposits (Hem, 1985, p. 137). The concentration of barium in ground water in Prince William County ranges from below the USGS reporting limit of 2 to $1,000 \mu \mathrm{g} / \mathrm{L}$ (fig. 16) with a median concentration of $44 \mu \mathrm{g} / \mathrm{L}$. No sample exceeded the USEPA MCL of $2,000 \mu \mathrm{g} / \mathrm{L}$. Barium concentration tends to be slightly higher in the ground water from rocks of the hydrogeologic groups $(\mathrm{B}, \mathrm{B} 1$, and $\mathrm{C})$ in the Culpeper Basin than in the other groups because barite-filled fissures have been documented (Roberts, 1928 , p. 132), and barite may be present in the evaporitic deposits.

\section{Iron}

Iron commonly is present in ground water at low concentrations and usually is in the form of the ferrous ion $\left(\mathrm{Fe}^{2+}\right)$. The principal source of iron is igneous rock minerals that contain high iron content, such as pyroxenes, amphiboles, biotite, magnetite, and olivine. Iron also is present in sulfide ore bodies and in plant and organic debris in soils. The availability of iron for rock-water interactions is dependent upon the types of minerals present, the degree or intensity of oxidation and reduction, and $\mathrm{pH}$. Excessive concentration of iron in ground water can cause staining of laundry and plumbing fixtures with red precipitates of ferric oxides and oxyhydroxides (Hem, 1985, p. 77) and impart a metallic taste to the water. The concentration of iron in ground water in Prince William County ranges from below the USGS reporting limit of 3 to $13,000 \mu \mathrm{g} / \mathrm{L}$ (fig. 16) with a median concentration of $8 \mu \mathrm{g} / \mathrm{L}$. The USEPA SMCL of $300 \mu \mathrm{g} / \mathrm{L}$ was exceeded in 9 (about 10 percent) of the 88 water samples from wells (fig. 17). The distribution of iron concentration in ground water is fairly uniform for all of the hydrogeologic groups except for groups $\mathrm{E}$ and $\mathrm{F}$. The high iron concentration in hydrogeologic group $\mathrm{E}$ is in response to the presence of mafic rocks (phyllite, schist, and slate) containing abundant ferromagnesian minerals coupled with low dissolved oxygen concentrations. The low dissolved oxygen concentration, abundance of organic material, and long ground-water residence times may explain the elevated iron concentration for hydrogeologic group F. Low iron concentration is characteristic of ground water from rocks in hydrogeologic groups $\mathrm{A}, \mathrm{B}, \mathrm{B} 1$, and $\mathrm{C}$. The rocks in hydrogeologic group A contain sparse amounts of iron-bearing minerals; however, the acidic ground water in this group is conducive to the dissolution of locally occurring zones of iron-bearing minerals. The basic (alkaline) ground water in the Culpeper Basin is not conducive to the dissolution of iron-bearing minerals.

\section{Manganese}

Manganese is a divalent metal that has similar chemical characteristics as iron, and it is present in many igneous and metamorphic minerals (olivines, pyroxene, and amphibole), basalt, and carbonates. Accumulation of manganese in tree leaves by metabolic activity has been documented (Hem, 1985, p. 86). Slack and Feltz (1968) showed that fallen leaves had an effect on manganese concentrations in a small stream in Virginia during certain times of the year. Elevated concentration of manganese can form dark red, brown, or black stains on plumbing fixtures. The concentration of manganese in ground water in Prince William County ranges from below the USGS reporting limit of 1.0 to $420 \mu \mathrm{g} / \mathrm{L}$ (fig. 16) with a median concentration of $3 \mu \mathrm{g} / \mathrm{L}$. The USEPA SMCL of $50 \mu \mathrm{g} / \mathrm{L}$ was exceeded in 16 (about 18 percent) of 

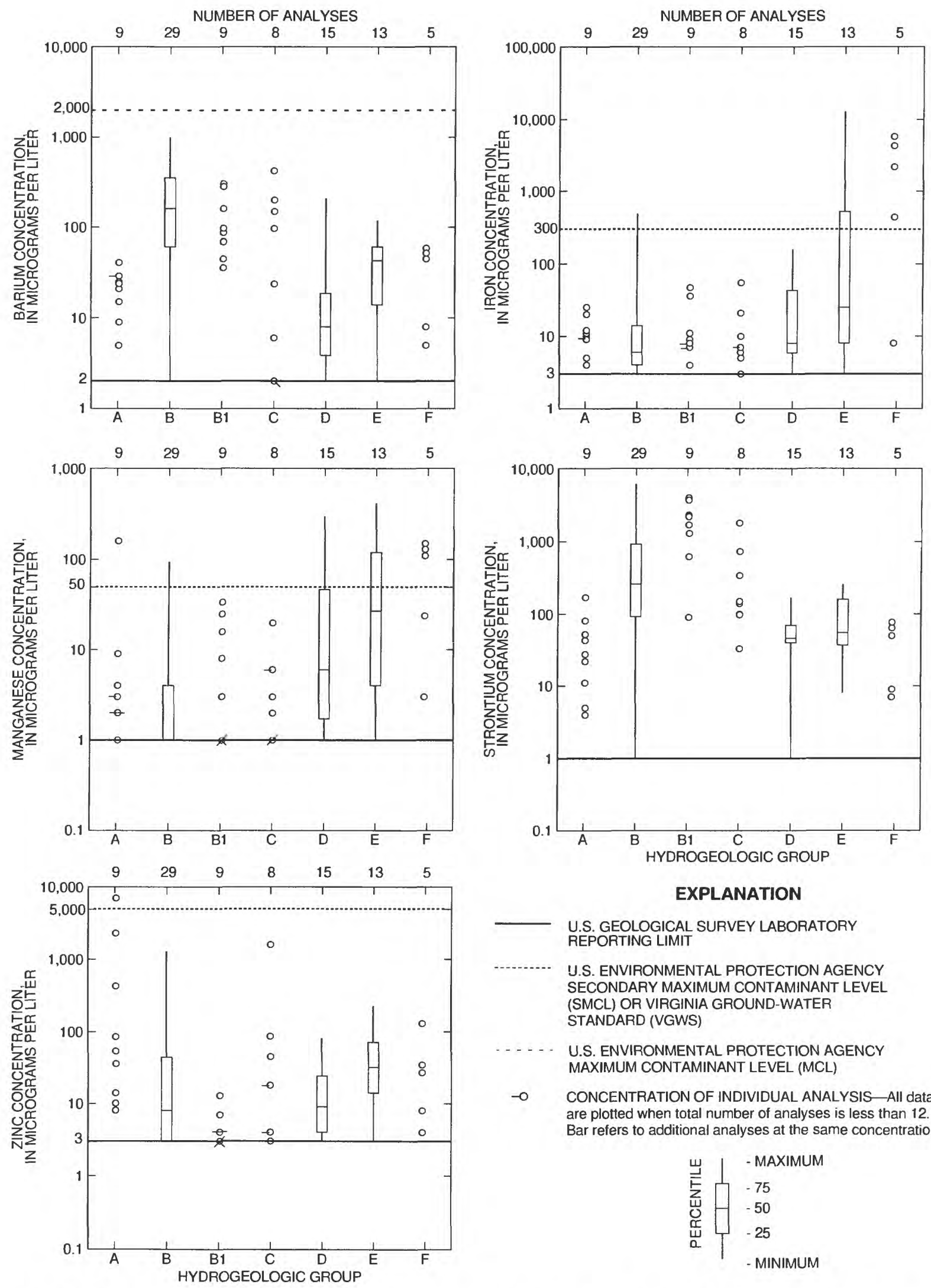

EXPLANATION

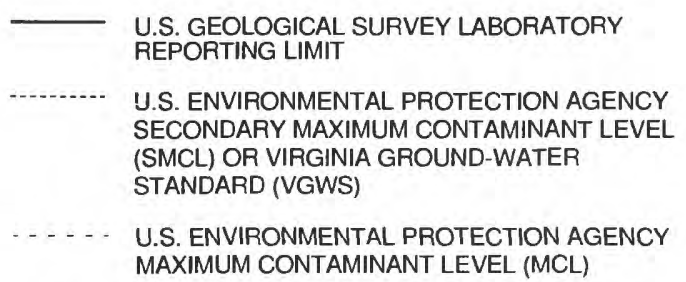

$-0$

CONCENTRATION OF INDIVIDUAL ANALYSIS—All data are plotted when total number of analyses is less than 12. Bar refers to additional analyses at the same concentration.

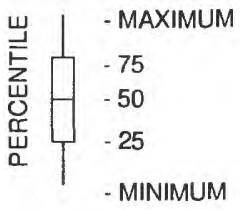

Figure 16. Summaries of analysis of selected trace metals in ground water in Prince William County, Virginia. 


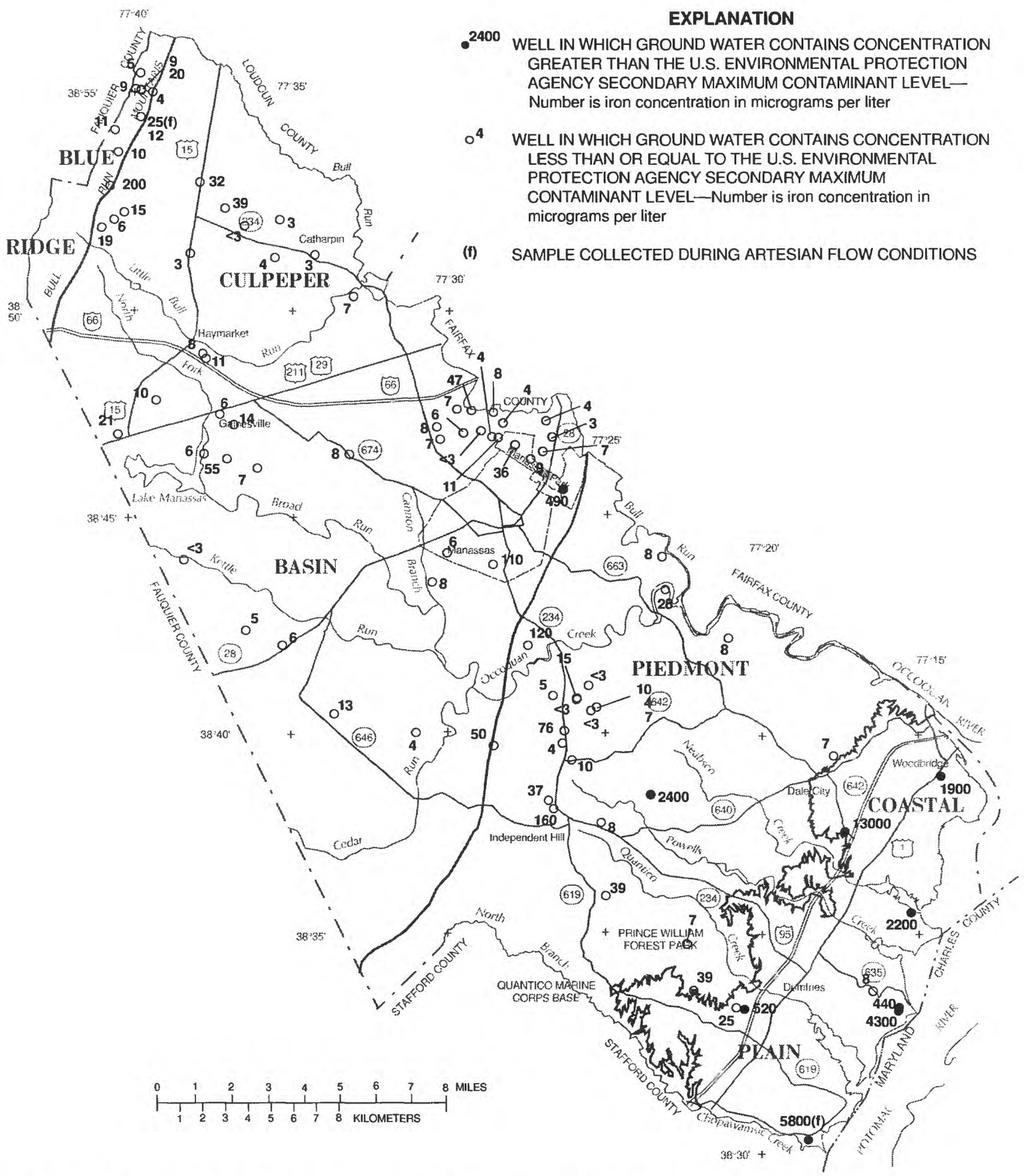

Figure 17. Concentrations of iron in ground water in Prince William County, Virginia. 
the 88 water samples from wells (fig 18). The distribution of manganese for each hydrogeologic group is similar to the distribution of iron concentrations. The explanations presented for the high concentrations of iron in the samples from hydrogeologic groups $\mathrm{E}$ and $F$ apply to the distribution of manganese concentrations. The sample from well 49V52, which is near the crest of Bull Run Mountain and within hydrogeologic group A, has a manganese concentration of $160 \mu \mathrm{g} / \mathrm{L}$. The occurrence of such a high manganese concentration is either in response to the local presence of similar zones of iron mentioned in the previous discussion or in the effect of aggressive water on the pipe in the well.

\section{Strontium}

Strontium is another alkaline-earth metal detected in ground water and has similar chemical characteristics as calcium. The major sources of strontium are igneous rock minerals, strontianite $\left(\mathrm{SrCO}_{3}\right)$ and celestite $\left(\mathrm{SrSO}_{4}\right)(\mathrm{Hem}, 1985$, p. 134). The concentration of strontium in ground water in Prince William County ranges from below the USGS reporting limit of 1 to $6,200 \mu \mathrm{g} / \mathrm{L}$ (fig. 16) with a median concentration of $95 \mu \mathrm{g} / \mathrm{L}$. Strontium concentration tends to be slightly higher in the ground water from rocks in the hydrogeologic groups $(B, B 1, C)$ of the Culpeper Basin than those in the other groups. Strontium-bearing minerals - strontianite and celestite - are commonly associated with barite (Hurlbut and Klein, 1977, p. 306) and also may fill fissures and exist in the evaporitic deposits within the Culpeper Basin.

\section{Zinc}

Zinc is a divalent metal $\left(\mathrm{Zn}^{2+}\right)$ commonly found in ground water. Zinc is a principal component of paints, brass, bronze, and galvanized pipe. No harmful health effects are associated with the presence of zinc, but elevated concentrations can be detected by taste (Hem, 1985, p. 142). The concentration of zinc in ground water in Prince William County ranges from below the USGS reporting limit of 3 to $7,100 \mu \mathrm{g} / \mathrm{L}$ (fig. 16) with a median concentration of $10 \mu \mathrm{g} / \mathrm{L}$. The USEPA SMCL of $5,000 \mu \mathrm{g} / \mathrm{L}$ was exceeded in only 1 (about 1 percent) of the 88 water samples from wells. New brass fittings were installed by the owner on well $49 \mathrm{~V} 52$, which is finished in rocks of hydrogeologic group A, for the purpose of collecting the water sample. The elevated zinc concentration of $7,100 \mu \mathrm{g} / \mathrm{L}$ is probably related to the exposure of these fittings to the aggressive and corrosive water from this well. The other water samples from hydrogeologic group A tend to have higher concentrations of zinc than those of the other groups and are probably related to similar conditions mentioned for well 49V52. Ground water from rocks of the other hydrogeologic groups that have low $\mathrm{pH}$ and alkalinity, and high concentration of dissolved oxygen may have elevated zinc concentration.

Ground water from rocks of hydrogeologic groups B and $\mathrm{B} 1$ tend to have Langlier saturation indices that indicate the water precipitates calcium carbonate, which forms a coating on the inside of the pipes and plumbing fixtures thus limiting interaction with the water.

\section{Dissolved Organic Carbon}

Dissolved organic carbon (DOC) is a complex composite of organic molecules dissolved in water that are smaller than $0.45 \mu$. (Thurman, 1985, p.10). A major source of DOC is from the decomposition of organic matter in soils (Chapelle, 1993, p. 242). DOC is an important complexing agent for metals (Schiff and others, 1990, p. 2949), can increase the weathering rates of minerals (Drever, 1988), and can affect the mobility and transport of metals and organic contaminants by increasing the solubility of these constituents (Stumm and Morgan, 1981). The concentration of DOC in ground water in Prince William County ranges from 0.2 to $1.9 \mathrm{mg} / \mathrm{L}$ with a median value of $0.4 \mathrm{mg} / \mathrm{L}$. The distribution of DOC concentrations is uniform throughout the county, and it is present at concentrations normally reported for ground waters-generally less than $2 \mathrm{mg} / \mathrm{L}$ (Thurman, 1985 , p. 14).

\section{Radon-222}

Radon-222 ( $\left.{ }^{222} \mathrm{Rn}\right)$ is a naturally occurring, colorless, odorless, chemically inert, alpha-particleemitting, noble gas produced by the radioactive decay of uranium-238 and radium-226, and it has a half-life of 3.82 days (Hall and others, 1987, p. 16). The presence of ${ }^{222} \mathrm{Rn}$ in ground water and indoor air is a concern to public health officials because ${ }^{222} \mathrm{Rn}$ gas and its progeny are known carcinogens, primarily causing lung cancer by inhalation. The USEPA MCL for ${ }^{222} \mathrm{Rn}$ in indoor air is $4 \mathrm{pCi} / \mathrm{L}$ and ground water with 10,000 $\mathrm{pCi} / \mathrm{L}$ of ${ }^{222} \mathrm{Rn}$ generally will contribute $1 \mathrm{pCi} / \mathrm{L}$ to indoor air (Otton and others, 1993, p. 14). Normally, 


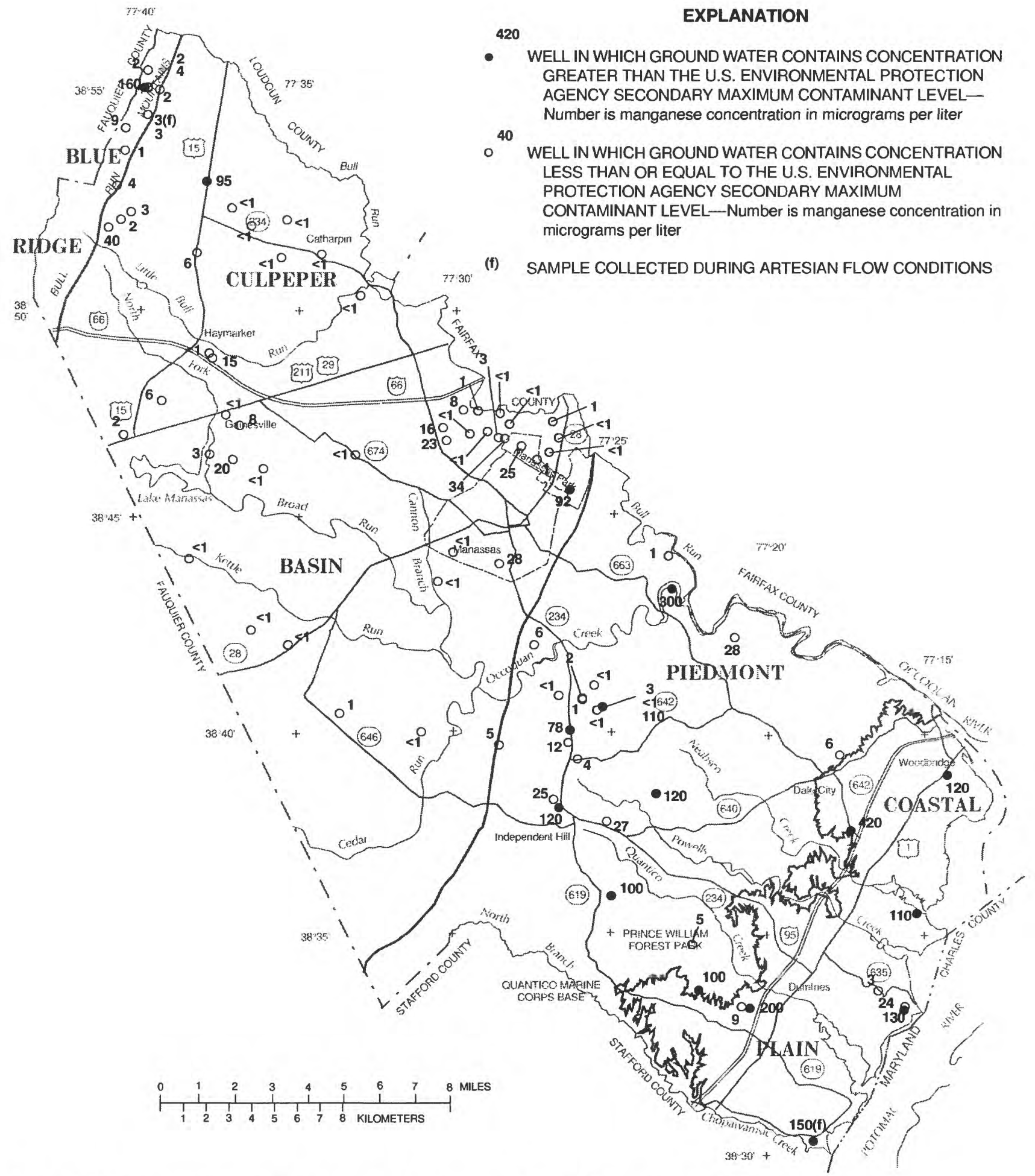

Figure 18. Concentrations of manganese in ground water in Prince William County, Virginia. 
dissolved ${ }^{222} \mathrm{Rn}$ concentration in ground water ranges from about 100 to nearly 3, 000,000 pCi/L (Otton and others, 1993, p. 5). The concentration of ${ }^{222} \mathrm{Rn}$ in ground water in Prince William County ranges from below the USGS reporting limit of 80 to $6,200 \mathrm{pCi} / \mathrm{L}$ (fig. 19) with a median concentration of $1,400 \mathrm{pCi} / \mathrm{L}$. The recently proposed USEPA MCL for drinking water of $300 \mathrm{pCi} / \mathrm{L}$ was exceeded in 82 (about 93 percent) of the 88 water samples from wells (fig. 20). The presence and distribution of ${ }^{222} \mathrm{Rn}$ are extremely variable. For example, wells 51T117, 51T118, and $51 \mathrm{~T} 119$ are adjacent to each other and the ${ }^{222} \mathrm{Rn}$ concentrations are $1,600,1,400$, and $5,400 \mathrm{pCi} / \mathrm{L}$, respectively for each sample. The concentration of ${ }^{222} \mathrm{Rn}$ is high in ground water from rocks of hydrogeologic groups D and E, yet not as high as those found in similar rocks to the south of the county near Hylas, Va. (Stanton and others, 1996). Ground water from rocks of hydrogeologic group $\mathrm{F}$ tends to have low ${ }^{222} \mathrm{Rn}$ concentration. The distribution of ${ }^{222} \mathrm{Rn}$ concentration in ground water in the rocks of the hydrogeologic groups of the Culpeper Basin is similar; but within these groups, hydrogeologic group B has a wide distribution, hydrogeologic group B1 tends to have high ${ }^{222} \mathrm{Rn}$ concentration, and hydrogeologic group $\mathrm{C}$ tends to have low ${ }^{222} \mathrm{Rn}$ concentration.

The elevated concentrations of ${ }^{222} \mathrm{Rn}$ in ground water from rocks of hydrogeologic groups D and $\mathrm{E}$ are related to the greater abundance of uranium and radium present in the rocks than in rocks of the other groups. Stanton and others (1996, p. 19) believe that ${ }^{222} \mathrm{Rn}$ is unsupported by dissolved radium-226 in ground water, and the location of uranium and radium near the mineral/water interface determines the mobility and enrichment of ${ }^{222} \mathrm{Rn}$ in ground water. The presence and distribution of ${ }^{222} \mathrm{Rn}$ concentration in ground water in the Culpeper Basin of the county are very similar to those in the Newark Basin of Pennsylvania and New Jersey (Sloto and Schreffler, 1994; Zapecza and Szabo, 1987). Thin, uranium-enriched black mudstones (lake beds) have been identified as the primary source of natural radioactivity in the Newark Basin of New Jersey, and locally occurring uraniumenriched zones in the arkosic sandstones of the Newark Basin can have elevated gross-alpha activities (Zapecza and Szabo, 1987, p. 64). Black mudstones (lake beds) are present in the Culpeper Basin and probably contain uranium-enriched zones, explaining the high ${ }^{222} \mathrm{Rn}$ concentration that is present in ground water from rocks of hydrogeologic group B1. The

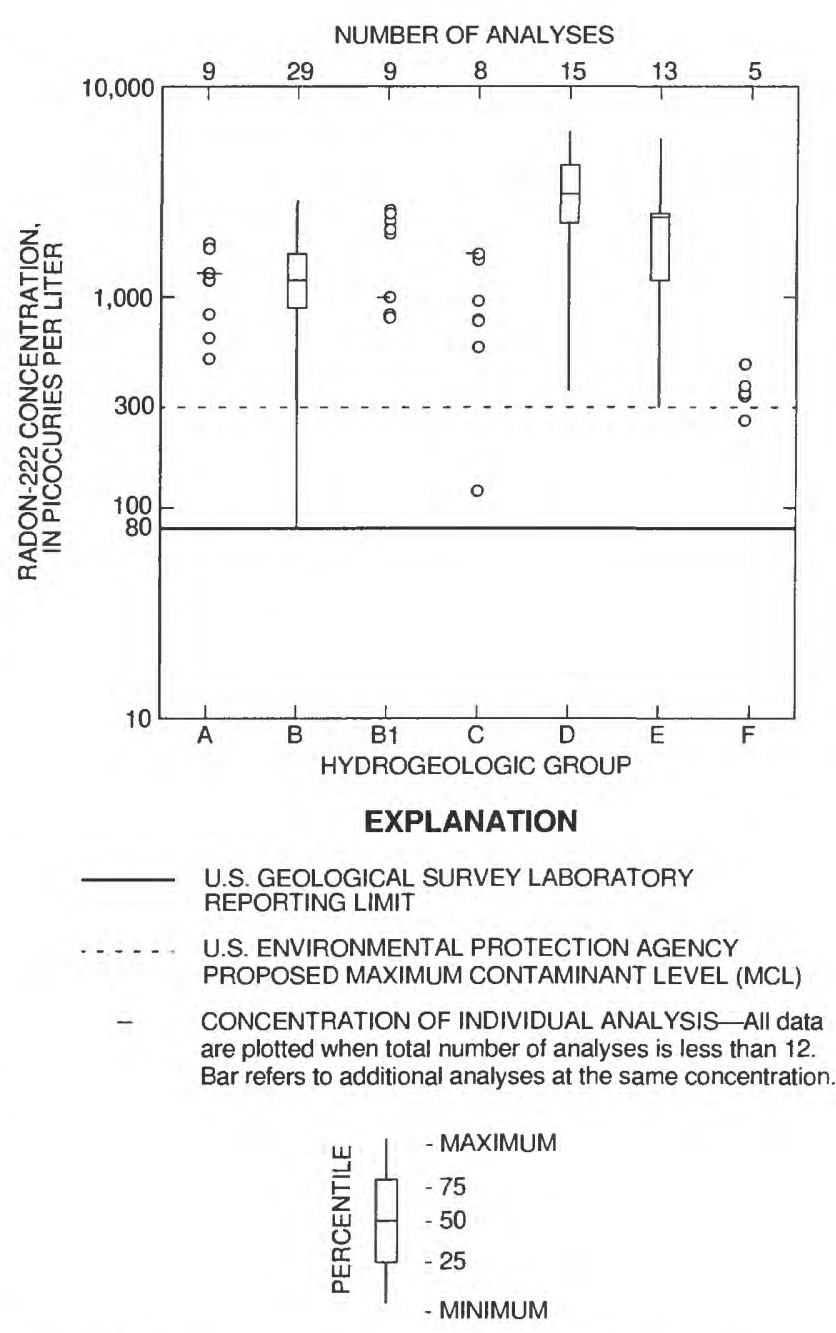

Figure 19. Summaries of analyses of radon-222 in ground water in Prince William County, Virginia.

wide distribution of ${ }^{222} \mathrm{Rn}$ concentration in hydrogeologic group B may be related to zones locally present in the sandstones that are enriched in uranium. The transferral of findings from the Newark Basin to the Culpeper Basin is justified because these two basins have similar depositional environments and settings. The actual concentration of ${ }^{222} \mathrm{Rn}$ in ground water does not directly correlate with a certain countsper-second interval on the total-count aeroradiometric contour map of the Culpeper Basin (Leavy and others, 1982); however, water from wells located within high radionuclide anomalies tend to have higher concentrations of ${ }^{222} \mathrm{Rn}$ than water from wells located in proximity, yet outside of these anomalies. 


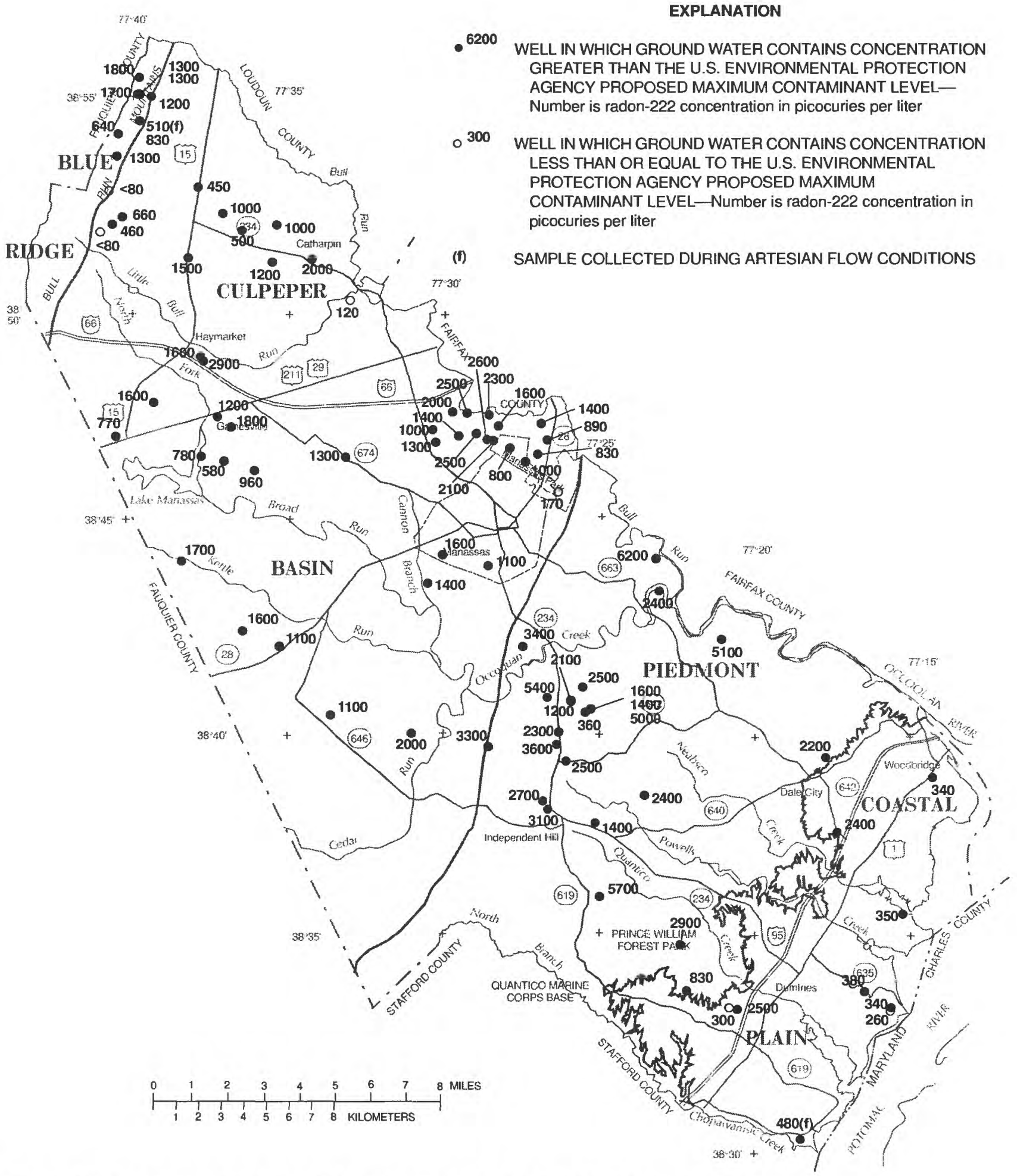

Figure 20. Concentrations of radon-222 in ground water in Prince William County, Virginia. 


\section{Water Types}

The classification of water by "type" simply is a method of indicating the predominant cations and anions that are present in that water. The designation of water types considers only the relative concentration of the ionic constituents and not the absolute concentration of dissolved constituents (Briel, 1993, p. 5). Trilinear diagrams are used commonly to represent and compare analyses of ground water. Calciummagnesium bicarbonate is the predominant water type exhibited by the water samples from wells in Prince William County (fig. 21) In this type of water, the sum of the milliequivalents of calcium plus magnesium is greater than 50 percent of the total milliequivalents per liter of cations - calcium usually is predominant - in solution, and bicarbonate is the predominant anion (greater than 50 percent). The concentrations outlined

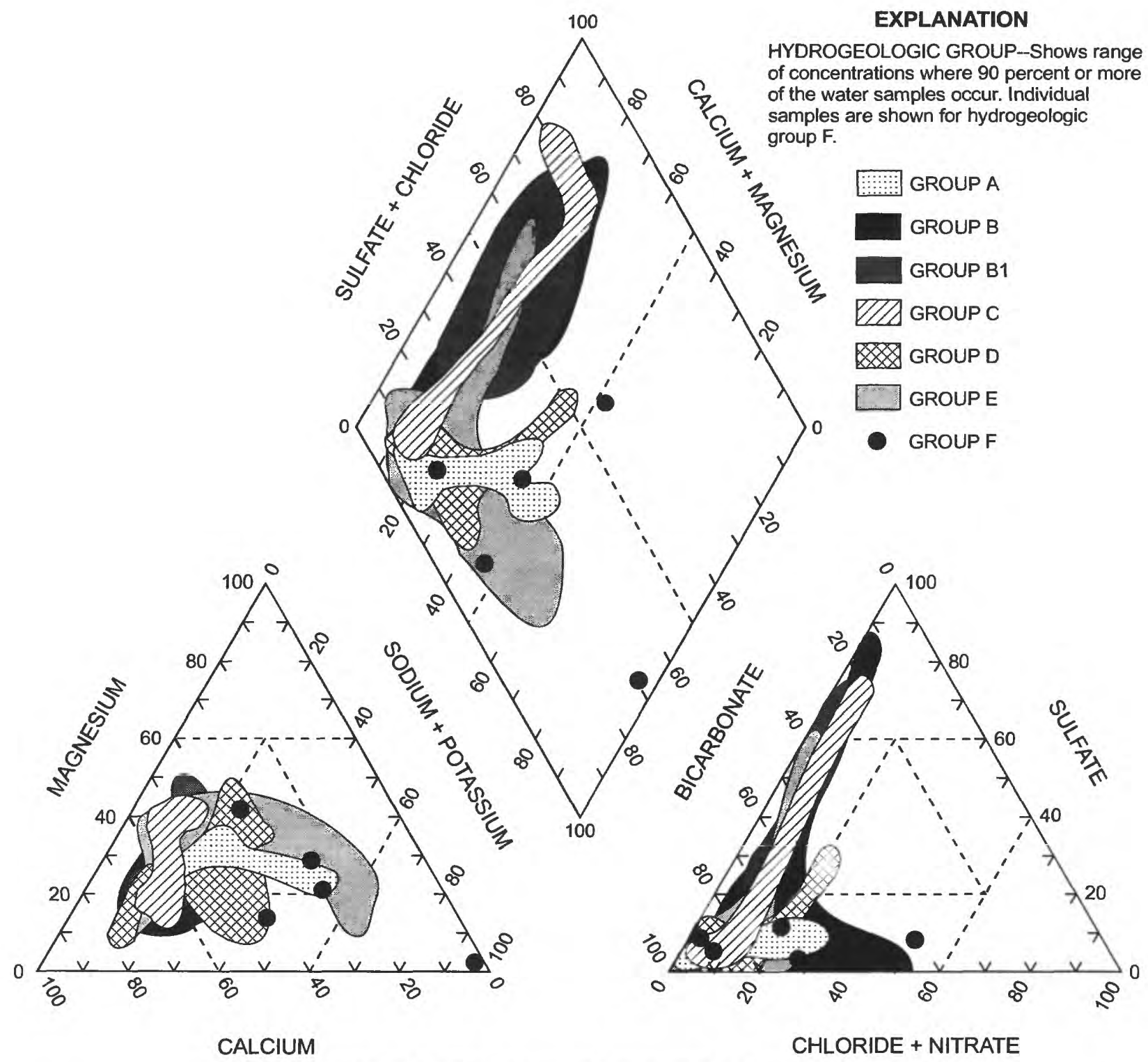

PERCENT OF TOTAL MILLIEQUIVALENTS PER LITER

Figure 21. Major-ion composition of ground water in Prince William County, Virginia. 
for each hydrogeologic group on figure 21, except group $\mathrm{F}$, represent the range of concentrations in which 90 percent or more of the water samples plot. The ground water in the Culpeper Basin (hydrogeologic groups $\mathrm{B}$ and $\mathrm{C}$ ) tends to be either calciummagnesium bicarbonate or calcium-magnesium sulfate, whereas water from rocks of hydrogeologic group B1 predominantly is calcium-magnesium sulfate in response to the presence of gypsum. The declining yields of wells often reported in the Culpeper Basin may be the result of geochemical processes in response to the mixing of waters from zones of different types within an open (uncased) borehole. The rocks in hydrogeologic groups $A$ and D contain predominantly calcium-magnesium bicarbonate water. Ground water from rocks of hydrogeologic group $\mathrm{E}$ exhibits three types (1) calcium-magnesium sulfate, (2) calcium-magnesium bicarbonate, and (3) sodium bicarbonate. The many water types present within hydrogeologic group $\mathrm{E}$ are to be expected because several types of rocks are represented by this group.

No dominant water type can be identified for hydrogeologic group $\mathrm{F}$ because of the few samples available and the apparent randomness exhibited by the plots of their analyses (fig. 21). Well 52S51, however, produces water from 27 to $35 \mathrm{ft}$ below sea level and has sodium-chloride water type. Well 52S52, which is near well 52S51, produces sodiumbicarbonate water from zones 234 to $244 \mathrm{ft}$ and 260 to $280 \mathrm{ft}$ below sea level. This apparent stratification of water types within the Coastal Plain sediments indicates incomplete flushing of the upper zones, evolutionary water compositions along flow paths (Meisler and Knobel, 1994, p. 4), or possible brackish-water intrusion or encroachment from the Potomac River. Brackish-water intrusion has been identified just across the Potomac River in Maryland (Hiortdahl, in press).

\section{RECHARGE AGES OF GROUND WATER}

Estimates of recharge ages of ground water provides valuable information concerning the groundwater-flow systems and can aid in the conceptualization and subsequent evaluation of these systems. Because withdrawals from wells are essentially discharges from the ground-water system, recharge ages are equivalent to the time for ground water to move through the entire system. Estimates of ground-water velocities, ground-water storage, and recharge rates can be obtained from the time of travel for ground water from recharge to discharge areas. Waterresource planners can use recharge ages to effectively design management and protection strategies for their ground-water resources. For example, water-resource planners can use recharge ages to help in the design of wellhead protection areas. Health professionals can use recharge ages to estimate when contaminated ground water might migrate to an active withdrawal well.

The recharge ages of ground water were determined for 58 water samples from 57 wells (fig. 7) in Prince William County by sampling and analytical methods developed by Busenberg and Plummer (1992), which use chlorofluorocarbons as dating tools. Chlorofluorocarbons (CFC's) are stable synthetic organic compounds that were first manufactured in the 1930's and are used as refrigerants, aerosol propellants, cleaning agents, solvents, and blowing agents in the production of foam rubber and plastics (Busenberg and Plummer, 1992). CFC's are eventually released to the atmosphere and hydrosphere and depletion of the Earth's ozone layer has been attributed to the rapid accumulation of these compounds in the atmosphere (Molina and Rowland, 1974). The method developed by Busenberg and Plummer (1992) uses two CFC's as dating tools - trichlorofluoromethane $\left(\mathrm{CCl}_{3} \mathrm{~F}, \mathrm{~F}-11\right.$, Freon 11) and dichlorodifluoromethane $\left(\mathrm{CCl}_{2} \mathrm{~F}_{2}, \mathrm{~F}-12\right.$, Freon 12). These two compounds make up 77 percent of total global production of CFC's (Derra, 1990). CFC's have been used to date ground water in a variety of hydrogeologic settings (Busenberg and Plummer, 1991; 1992; Busenberg and others, 1993; Dunkle and others, 1993; Reilly and others, 1994).

Atmospheric partial pressures of CFC's are determined by Henry's Law from the recharge temperature and measured concentrations of F-11 and F-12 in the ground water. These calculated partial pressures are compared with the modeled atmospheric growth (fig. 22) of CFC's to determine the CFC-model recharge date, which equates to the time that the water was isolated from air in the unsaturated zone. The CFC-model recharge age simply is the difference between the date of sample collection and the estimated date the water entered the ground-water system. A recharge-water temperature of $9^{\circ} \mathrm{C}$, which was used in the calculations of CFC's partial pressures, was determined on the basis of argon/nitrogen ratios in 18 dissolved gas samples collected throughout Prince William County (fig. 23). The recharge-water 


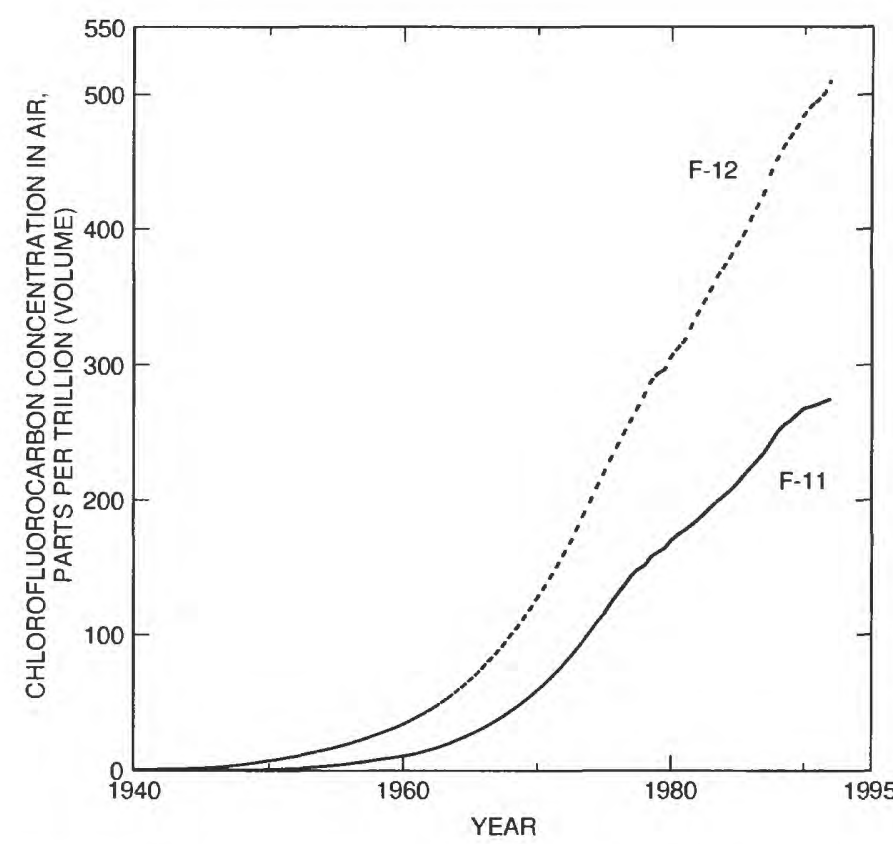

Figure 22. Concentrations of chlorofluorocarbon-11 and chlorofluorocarbon-12 in the atmosphere. Modified from Busenberg and others (1993).

temperature is determined by projecting from the sample to the recharge-water-temperature axis along a line parallel to the temperature lines in figure 23. Interested readers may consult Busenberg and others (1993) for a more detailed explanation. The estimated recharge-water temperature of $9^{\circ} \mathrm{C}$ is less than the mean annual temperature of $13.3^{\circ} \mathrm{C}$, which indicates that most of the recharge occurs in the colder months of the year when plants are dormant and evapotranspiration is negligible. The stable isotopes - deuterium and oxygen-18 - support this conclusion because the isotopic ratios (fig. 24) are light, indicating recharge of winter precipitation, which is depleted in deuterium and oxygen-18 (Coplen, 1993, p. 234). If most of the recharge occurred in the summer months, the isotopic ratios would be heavy because the lighter isotopes are removed by evaporation.

Results (table 7) from the use of CFC's as dating tools indicate that parts of the ground-water-flow systems in Prince William County are younger than 45 years, especially in the consolidated rock aquifers. The recharge ages estimated from F-11 and F-12 concentrations generally were within 5 years of each other, and F-11 model recharge ages were usually older than those for F-12. The samples with the greatest discrepancies between the F-11 and F-12 ages have low dissolved oxygen concentrations, suggesting that biodegradation of F-11 is occurring. Microbial activity in reducing ground-water environments tends to prefer F-11 over F-12 (Busenberg and Plummer, 1992, p. 2266). Precise dating in urban settings was not possible because samples from wells in these areas were commonly contaminated with CFC's in excess of modern atmospheric concentrations (Nelms and Ahlin, 1993). Concentrations of atmospheric CFC's in urban areas tend to be significantly higher than those in nonurban areas (Busenberg and others, 1993). Additional samples contaminated with CFC's are from wells located in non-urban areas that may be affected by anthropogenic activities. The presence of CFC's in the ground water, however, indicates that at least some of the water is younger than 45 years.

The final F-11 and F-12 model recharge ages used during this investigation tend to be conservative because the selected ages are associated with the lowest (older) CFC's concentrations measured. The spatial distribution of F-11 and F-12 model recharge ages are shown in figures 25 and 26 , respectively. The abundance of wells that have samples contaminated with CFC's in the Manassas/Manassas Park area is quite evident from these figures, and the oldest recharge ages tend to occur in the unconsolidated sediments of the Coastal Plain. The CFC's model recharge ages are considered to be minimum estimates because ground-water samples tend to represent mixtures of waters from different zones, especially in the consolidated-rock aquifers. Samples from high capacity wells tend to have younger recharge ages than those estimated for samples from domestic wells. The higher pumping rates in the high capacity wells may cause an increase in the amount of young waters mixed with waters that are older than 45 years.

Although the CFC-model recharge ages probably represent mixtures of ground water, the depths of water-producing zones reported on well-completion forms can be used to estimate depths at which ground water contains CFC's; but, especially for older wells, these depths often are not reported. Ground water, however, tends to equilibrate with the temperature of the rocks in the aquifer and the depth of circulation can be estimated from the difference between the measured water temperature and the mean annual air temperature divided by the local geothermal gradient (Mazor, 1991, p. 46). The geothermal gradient for the Culpeper Basin and Piedmont in this part of Virginia is $0.8^{\circ} \mathrm{C}$ per $100 \mathrm{ft}$ (W.S. McClung, Virginia Polytechnic Institute and State University, written commun., 


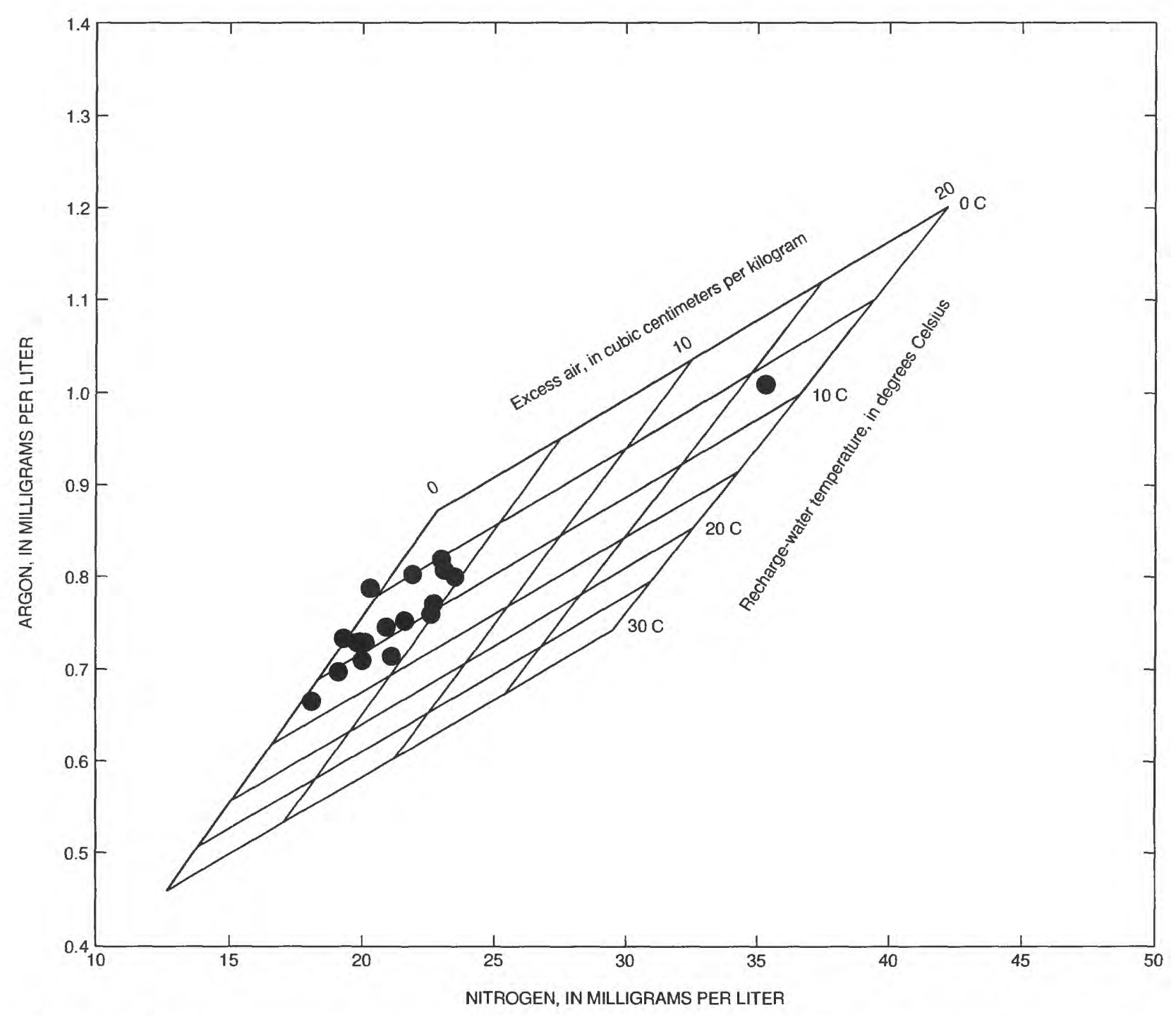

Figure 23. Dissolved nitrogen and argon compositions of ground water in Prince William County, Virginia.

1979). The relation between depth of ground-water circulation and CFC's concentrations is extremely variable in the Culpeper Basin and in the Piedmont, which is to be expected in consolidated rock aquifers. The Blue Ridge and Coastal Plain are not included in the analysis because the geothermal gradients within these two provinces are unknown for this part of Virginia. The deepest water-producing zone that contains CFC's, determined from the analysis of temperature equilibration, is $840 \mathrm{ft}$ below land surface in well 51U104G. This well is in the Culpeper Basin and also within the high ground-water pumpage area in Manassas and Manassas Park.

Stratification of CFC's-model recharge ages is evident in the Coastal Plain. Well 52 S47 produces water from a zone that is 20 to $40 \mathrm{ft}$ above sea level; whereas well 52S51 is downgradient and produces water from a zone that is from 27 to $35 \mathrm{ft}$ below sea level. The respective F-12 model recharge ages are different by 10 years - 29 and 39 years. Below these altitudes in the Coastal Plain, CFC's were not detected in samples from wells 52S52 and 52S44 and tritium concentrations are extremely low (fig. 27). The F-11 and F-12 model recharge ages for samples from both of these wells are older than 45 years. Well $53 \mathrm{~T} 56$ has a ground-water F-11 model recharge age of 33 years and is in the northern part of the Coastal Plain in the county, but the unconsolidated sediments are cased off and production is from the underlying bedrock at depths from 128 to $228 \mathrm{ft}$ below sea level. The presence of young waters in the bedrock underlying the Coastal Plain sediments supports the possibility of 


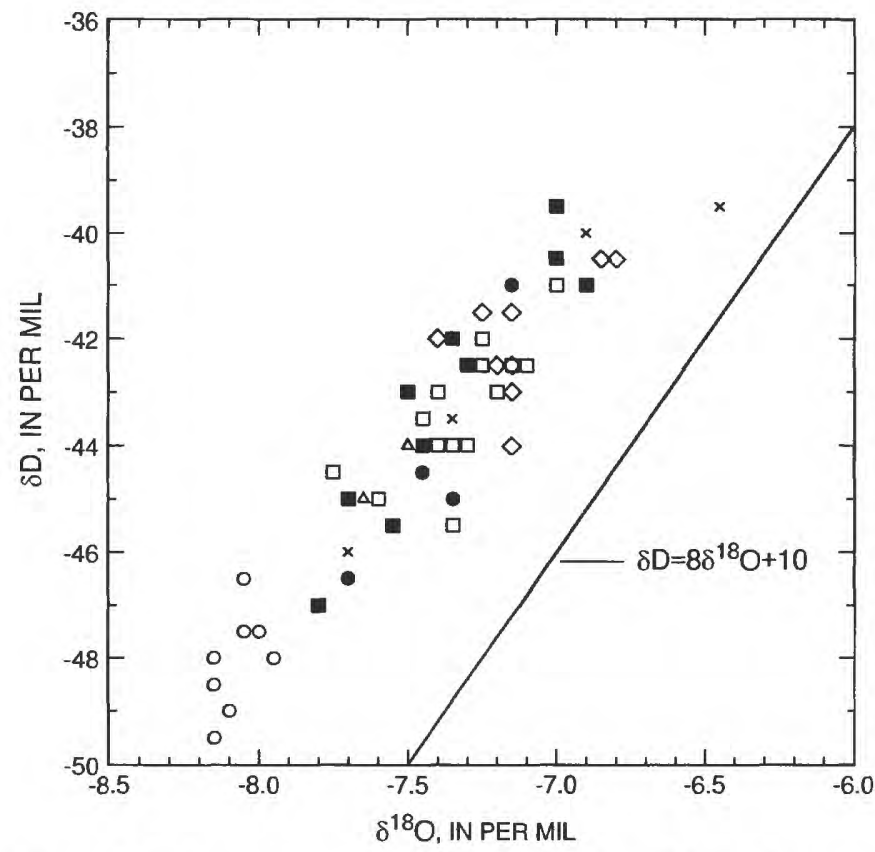

\begin{tabular}{|c|c|}
\hline \multicolumn{2}{|c|}{ EXPLANATION } \\
\hline HYDR & AEOLOGIC \\
\hline 0 & GROUP A \\
\hline$\square$ & GROUP B \\
\hline$\diamond$ & GROUP B1 \\
\hline - & GROUP C \\
\hline$\Delta$ & GROUP D \\
\hline . & GROUP E \\
\hline$x$ & GROUP F \\
\hline
\end{tabular}

Figure 24. Isotopic composition of deuterium $(\delta \mathrm{D})$ and oxygen $-18\left(\delta^{18} \mathrm{O}\right)$ in ground water in Prince William County, Virginia. The mean global meteoric water line is also shown.

subsurface ground-water discharge from the Piedmont to the Coastal Plain sediments.

Some of the youngest CFC's model recharge ages and highest tritium concentrations (fig. 27) occur in an area of the Piedmont just north of Independent Hill where the thickness of overburden ranges from 60 to $110 \mathrm{ft}$. Water from wells $51 \mathrm{~T} 29 \mathrm{E}, 51 \mathrm{~T} 117,51 \mathrm{~T} 118$, 51T119, 51T172, and 51T173 had F-11 model recharge ages that ranged from 2 to 13 years with only samples from wells $51 \mathrm{~T} 118$ and 51T119 being contaminated and F-12 model recharge ages that ranged from contaminated to 6 years. All of these wells are used for public supply; their yields range from 15 to $45 \mathrm{gal} / \mathrm{min}$, and their water-producing zones range from 110 to $360 \mathrm{ft}$ below land surface. Evidently, macropores or remnant rock fabric in the saprolite at land surface and shallow depths allows for rapid movement through the unconsolidated part of the ground-water-flow system in this part of the Piedmont. In addition, the saprolite in this area was observed to be very coarse grained, locally.

The CFC's-model recharge ages can aid in the interpretation of differences detected in water-quality analyses of ground water. Well $51 \mathrm{U} 4 \mathrm{H}$ is a low demand well with water that has high concentrations of sulfate $(800 \mathrm{mg} / \mathrm{L})$, TDS $(1,280 \mathrm{mg} / \mathrm{L})$, iron $(490$ $\mu \mathrm{g} / \mathrm{L})$, and manganese $(92 \mu \mathrm{g} / \mathrm{L})$, which probably are a consequence of either long ground-water residence times (38 years), infrequent usage, or greater percentage of old water mixed with younger waters. Another example, well 49V53, which is at the base of Bull Run Mountain, intersects the western border fault of the Culpeper Basin, and water flows at $5 \mathrm{gal} / \mathrm{min}$ with a head of about $40 \mathrm{ft}$ above land surface. Water zones penetrated during drilling are in the rocks of the Culpeper Basin (190 to $200 \mathrm{ft}$ below land surface) and in the rocks of the Blue Ridge (670 to 680,720 to 730 , and 760 to $770 \mathrm{ft}$ below land surface). The high potentiometric head in well 49V53 is believed to be derived from the lower water zones in the underlying Blue Ridge rocks. The water-quality analyses (table 8) show subtle differences that suggest the pumped sample is more indicative of water from rocks of the Blue Ridge because the values of the field properties, bicarbonate and TDS concentrations are slightly lower than those from the artesian flow sample. The CFCmodel recharge age of 27 years for the pumped sample is consistent with the younger ages determined for wells upgradient of well 49V53. It is believed that the contribution from the upper water zone in the rocks of the Culpeper Basin either is minimal or is depleted during pumping of well 49V53. 
Table 7. Concentrations of dissolved chlorofluorocarbon-11 and chloroiluorocarbon-12 and recharge dates of ground water in Prince William County, Virginia

[Detection limits of chlorofluorocarbons are less than 1 picogram per kilogram of solution. Atmospheric partial pressures of chlorofluorocarbons were calculated using a recharge temperature of 9 degrees Celsius at a barometric pressure of 760 millimeters of mercury. CFC, chlorofluorocarbon: F-11, chlorofluorocarbon-11; F-12, chlorofluorocarbon-12; pg/kg, picogram per kilogram of solution; pptv, parts per trillion volume; $\mathrm{CNT}$, contaminated- $\mathrm{CFC}$ concentration greater than modern and sample cannot be dated]

\begin{tabular}{|c|c|c|c|c|c|c|c|c|c|}
\hline \multirow{2}{*}{$\begin{array}{c}\text { Local } \\
\text { well } \\
\text { number }\end{array}$} & \multirow[b]{2}{*}{$\begin{array}{l}\text { Hydrogeologic } \\
\text { group }\end{array}$} & \multirow[b]{2}{*}{ Date } & \multirow[b]{2}{*}{ Time } & \multicolumn{2}{|c|}{$\begin{array}{c}\text { Concentration } \\
\text { in solution }\end{array}$} & \multicolumn{2}{|c|}{$\begin{array}{c}\text { Calculated atmospheric } \\
\text { partial pressures }\end{array}$} & \multicolumn{2}{|c|}{$\begin{array}{l}\text { Model CFC } \\
\text { recharge dates }\end{array}$} \\
\hline & & & & $\begin{array}{c}\mathrm{F}-11 \\
(\mathrm{pg} / \mathrm{kg})\end{array}$ & $\begin{array}{c}\mathrm{F}-12 \\
(\mathrm{pg} / \mathrm{kg})\end{array}$ & $\begin{array}{c}\text { F-11 } \\
\text { (pptv) }\end{array}$ & $\begin{array}{c}\text { F-12 } \\
\text { (pptv) }\end{array}$ & $F-11$ & $F-12$ \\
\hline \multirow[t]{3}{*}{$49 \mathrm{~T} 74$} & B & $09-05-91$ & 1220 & $90,171.9$ & $1,108.0$ & $29,393.0$ & $1,590.1$ & CNT & CNT \\
\hline & & & 1230 & $61,899.4$ & 155.2 & $20,177.2$ & 222.7 & CNT & 1985 \\
\hline & & & 1240 & $61,013.6$ & 166.9 & $19,888.4$ & 239.5 & CNT & 1986 \\
\hline \multirow[t]{3}{*}{$49 \cup 73$} & B & $08-22-91$ & 1003 & 40.0 & 123.5 & 13.0 & 177.3 & 1961 & 1980 \\
\hline & & & 1015 & 31.7 & 121.8 & 10.3 & 174.8 & 1959 & 1979 \\
\hline & & & 1035 & 30.7 & 127.4 & 10.0 & 182.8 & 1959 & 1980 \\
\hline \multirow{3}{*}{$49 \cup 74$} & $\mathrm{C}$ & $09-04-91$ & 1100 & 54.7 & 26.5 & 17.8 & 38.0 & 1962 & 1961 \\
\hline & & & 1105 & $1,971.7$ & 745.9 & 642.7 & $1,070.5$ & CNT & CNT \\
\hline & & & 1115 & 63.5 & 26.5 & 20.7 & 38.1 & 1963 & 1961 \\
\hline \multirow[t]{3}{*}{$49 \cup 75$} & C & $08-28-91$ & 1010 & 643.7 & 306.8 & 209.8 & 440.3 & 1983 & 1988 \\
\hline & & & 1030 & $1,053.6$ & 497.1 & 343.4 & 713.5 & CNT & CNT \\
\hline & & & 1040 & 653.5 & 309.7 & 213.0 & 444.4 & 1984 & 1988 \\
\hline \multirow[t]{3}{*}{$49 V 49$} & A & $08-26-91$ & 1256 & $9,557.3$ & 503.7 & $3,115.4$ & 722.8 & CNT & CNT \\
\hline & & & 1305 & $8,453.3$ & 512.0 & $2,755.5$ & 734.8 & CNT & CNT \\
\hline & & & 1315 & $5,339.8$ & 588.7 & $1,740.6$ & 844.9 & $\mathrm{CNT}$ & CNT \\
\hline \multirow[t]{3}{*}{$49 \mathrm{~V} 50$} & A & $08-26-91$ & 1420 & $5,668.5$ & 240.1 & $1,847.7$ & 344.5 & $\mathrm{CNT}$ & 1982 \\
\hline & & & 1430 & $3,836.8$ & 243.0 & $1,250.7$ & 348.8 & CNT & 1983 \\
\hline & & & 1440 & $3,223.3$ & 235.9 & $1,050.7$ & 338.5 & CNT & 1982 \\
\hline \multirow[t]{3}{*}{$49 \mathrm{~V} 52$} & A & $08-26-91$ & 1056 & $1,144.9$ & 760.4 & 373.2 & $1,091.3$ & CNT & CNT \\
\hline & & & 1110 & 399.8 & $1,275.5$ & 130.3 & $1,830.6$ & 1976 & CNT \\
\hline & & & 1115 & 426.2 & $1,353.1$ & 138.9 & $1,941.8$ & 1976 & CNT \\
\hline \multicolumn{10}{|l|}{ 49V 53: } \\
\hline \multirow[t]{3}{*}{ (Artesian flow) } & A & $08-27-91$ & 1250 & 337.4 & 187.0 & 110.0 & 268.4 & 1974 & 1977 \\
\hline & & & 1255 & 331.3 & 186.6 & 108.0 & 267.8 & 1974 & 1977 \\
\hline & & & 1305 & 323.7 & 258.4 & 105.5 & 370.8 & 1974 & 1984 \\
\hline \multirow[t]{3}{*}{ (Pumped) } & A & $08-27-91$ & 1415 & 77.3 & 38.0 & 25.2 & 54.5 & 1964 & 1964 \\
\hline & & & 1420 & 95.7 & 48.8 & 31.2 & 70.1 & 1965 & 1965 \\
\hline & & & 1430 & 105.8 & 53.8 & 34.5 & 77.2 & 1966 & 1966 \\
\hline \multirow[t]{3}{*}{$49 \mathrm{~V} 55$} & A & $02-04-91$ & 1339 & $6,567.3$ & 231.0 & $2,140.7$ & 331.6 & $\mathrm{CNT}$ & 1982 \\
\hline & & & 1344 & $4,086.6$ & 151.5 & $1,332.1$ & 217.4 & CNT & 1975 \\
\hline & & & 1351 & $4,274.7$ & 210.0 & $1,393.4$ & 301.4 & $\mathrm{CNT}$ & 1980 \\
\hline \multirow[t]{3}{*}{$49 \mathrm{~V} 56$} & A & $02-04-91$ & 1231 & 406.5 & 168.9 & 132.5 & 242.4 & 1976 & 1976 \\
\hline & & & 1241 & 394.2 & 158.6 & 128.5 & 227.6 & 1975 & 1976 \\
\hline & & & 1253 & 346.7 & 146.7 & 113.0 & 210.5 & 1974 & 1975 \\
\hline \multirow[t]{3}{*}{49 V 57} & A & $08-27-91$ & 1025 & 818.2 & 291.4 & 266.7 & 418.3 & 1988 & 1987 \\
\hline & & & 1035 & 743.0 & 263.6 & 242.2 & 378.3 & 1986 & 1985 \\
\hline & & & 1045 & 704.7 & 251.3 & 229.7 & 360.7 & 1985 & 1983 \\
\hline $49 V 58$ & A & $02-04-91$ & 1052 & 91.4 & 84.4 & 29.8 & 121.1 & 1965 & 1970 \\
\hline & & & 1108 & 101.2 & 87.1 & 33.0 & 125.1 & 1966 & 1970 \\
\hline & & & 1116 & 101.7 & 84.4 & 33.1 & 121.1 & 1966 & 1970 \\
\hline $50 \mathrm{~T} 79$ & B & $09-04-91$ & 1340 & 383.5 & 205.8 & 125.0 & 295.3 & 1975 & 1979 \\
\hline & & & 1350 & 391.3 & 212.8 & 127.5 & 305.3 & 1975 & 1980 \\
\hline & & & 1400 & 389.1 & 240.0 & 126.8 & 344.4 & 1975 & 1982 \\
\hline 50 T 80 & B & $08-22-91$ & 1448 & 310.4 & 599.1 & 101.2 & 859.8 & 1973 & CNT \\
\hline & & & 1455 & 318.3 & 632.1 & 103.8 & 907.2 & 1973 & CNT \\
\hline & & & 1505 & 308.6 & 605.4 & 100.6 & 868.9 & 1973 & CNT \\
\hline
\end{tabular}


Table 7. Concentrations of dissolved chlorofluorocarbon-11 and chlorofluorocarbon-12 and recharge dates of ground water in Prince William County, Virginia-Continued

[Detection limits of chlorofluorocarbons are less than 1 picogram per kilogram of solution. Atmospheric partial pressures of chlorofluorocarbons were calculated using a recharge temperature of 9 degrees Celsius at a barometric pressure of 760 millimeters of mercury. CFC,

chlorofluorocarbon; F-11, chlorofluorocarbon-11; F-12, chlorofluorocarbon-12; pg/kg, picogram per kilogram of solution; pptv, parts per trillion volume; CNT, contaminated CFC concentration greater than modern and sample cannot be dated; MOD, CFC concentration equals modern; $<1945$, model CFC recharge dates earlier than 1945]

\begin{tabular}{|c|c|c|c|c|c|c|c|c|c|}
\hline \multirow{2}{*}{$\begin{array}{l}\text { Local } \\
\text { well } \\
\text { number }\end{array}$} & \multirow[b]{2}{*}{$\begin{array}{l}\text { Hydrogeologic } \\
\text { group }\end{array}$} & \multirow[b]{2}{*}{ Date } & \multirow[b]{2}{*}{ Time } & \multicolumn{2}{|c|}{$\begin{array}{c}\text { Concentration } \\
\text { in solution }\end{array}$} & \multicolumn{2}{|c|}{$\begin{array}{l}\text { Calculated atmospheric } \\
\text { partial pressures }\end{array}$} & \multicolumn{2}{|c|}{$\begin{array}{l}\text { Model CFC } \\
\text { recharge dates }\end{array}$} \\
\hline & & & & $\begin{array}{c}\mathrm{F}-11 \\
(\mathrm{pg} / \mathrm{kg})\end{array}$ & $\begin{array}{c}\mathrm{F}-12 \\
(\mathrm{pg} / \mathrm{kg})\end{array}$ & $\begin{array}{c}\text { F-11 } \\
\text { (pptv) }\end{array}$ & $\begin{array}{c}\text { F-12 } \\
\text { (pptv) }\end{array}$ & $\overline{F-11}$ & F-12 \\
\hline \multirow[t]{3}{*}{$50 \mathrm{~T} 81$} & B & $08-29-91$ & 1115 & $6,369.1$ & $2,444.0$ & $2,076.1$ & $3,507.5$ & CNT & CNT \\
\hline & & & 1135 & $5,597.6$ & $2,277.5$ & $1,824.6$ & 3.268 .6 & CNT & CNT \\
\hline & & & 1145 & $5,803.3$ & $2,424.6$ & $1,891.7$ & $3,479.7$ & CNT & CNT \\
\hline \multirow[t]{3}{*}{$50 \mathrm{U} 122$} & B & $09-11-91$ & 1240 & $1,165.2$ & $1,059.7$ & 379.8 & $1,520.8$ & CNT & CNT \\
\hline & & & 1250 & $1,135.4$ & $1,042.2$ & 370.1 & $1,495.7$ & CNT & CNT \\
\hline & & & 1300 & $1,159.5$ & $1,065.6$ & 378.0 & $1,529.3$ & CNT & CNT \\
\hline \multirow[t]{3}{*}{$50 \cup 123$} & $\mathrm{~B} 1$ & $08-21-91$ & 1444 & 908.2 & 2.312 .3 & 296.0 & $3,318.5$ & 1991 & CNT \\
\hline & & & 1452 & 888.4 & $2,274.4$ & 289.6 & $3,264.0$ & 1990 & CNT \\
\hline & & & 1500 & 896.3 & $2,274.4$ & 292.2 & $3,264.0$ & 1991 & CNT \\
\hline \multirow[t]{3}{*}{50 U124 } & B & $08-21-91$ & 0958 & 525.2 & 839.8 & 171.2 & $1,205.3$ & 1979 & CNT \\
\hline & & & 1014 & 545.9 & 800.8 & 177.9 & $1,149.3$ & 1980 & CNT \\
\hline & & & 1027 & 541.5 & 788.8 & 176.5 & $1,132.0$ & 1980 & CNT \\
\hline \multirow[t]{3}{*}{$50 \cup 128$} & $\mathrm{C}$ & $08-28-91$ & 1445 & 76.4 & 240.7 & 24.9 & 345.4 & 1964 & 1982 \\
\hline & & & 1455 & 74.9 & 232.3 & 24.4 & 333.3 & 1964 & 1982 \\
\hline & & & 1500 & 69.1 & 236.6 & 22.5 & 339.6 & 1964 & 1982 \\
\hline \multirow[t]{3}{*}{$50 \cup 133$} & B & $09-02-91$ & 1110 & 258.3 & 212.4 & 84.2 & 304.8 & 1972 & 1980 \\
\hline & & & 1125 & 276.9 & 232.6 & 90.3 & 333.8 & 1973 & 1982 \\
\hline & & & 1135 & 320.9 & 253.3 & 104.6 & 363.5 & 1974 & 1984 \\
\hline \multirow[t]{3}{*}{$50 \cup 135$} & B & $08-22-91$ & 1249 & 987.2 & 647.4 & 321.8 & 929.1 & CNT & CNT \\
\hline & & & 1300 & 14.5 & 18.9 & 4.7 & 27.2 & 1955 & 1958 \\
\hline & & & 1320 & 11.6 & 15.3 & 3.8 & 22.0 & 1955 & 1957 \\
\hline \multirow[t]{3}{*}{$50 \mathrm{U} 136$} & B & $09-03-91$ & 1405 & $37,853.6$ & $2,060.8$ & $12,339.0$ & $2,957.6$ & CNT & CNT \\
\hline & & & 1415 & $32,183.6$ & $1,719.0$ & $10,490.8$ & $2,467.0$ & CNT & CNT \\
\hline & & & 1420 & 28.377 .5 & $1,514.7$ & $9,250.1$ & $2,173.8$ & CNT & $\mathrm{CNT}$ \\
\hline \multirow[t]{3}{*}{$50 \cup 137$} & $\mathrm{C}$ & $08-28-91$ & 1245 & .0 & .0 & .0 & .0 & $<1945$ & $<1945$ \\
\hline & & & 1250 & .0 & .0 & .0 & .0 & $<1945$ & $<1945$ \\
\hline & & & 1300 & .0 & .0 & .0 & .0 & $<1945$ & $<1945$ \\
\hline \multirow[t]{3}{*}{$51 \mathrm{~S} 5$} & $\mathrm{E}$ & $08-13-91$ & 1055 & 259.4 & 106.3 & 84.6 & 152.5 & 1972 & 1972 \\
\hline & & & 1108 & 263.8 & 148.9 & 86.0 & 213.7 & 1972 & 1975 \\
\hline & & & 1120 & 257.0 & 107.2 & 83.8 & 153.8 & 1972 & 1972 \\
\hline \multirow[t]{3}{*}{$51 \mathrm{~T} 1 \mathrm{~A}$} & B & $08-29-91$ & 0935 & $3,257.2$ & 142.9 & $1,061.7$ & 205.0 & CNT & 1974 \\
\hline & & & 0945 & $3,106.8$ & 143.7 & $1,012.7$ & 206.2 & CNT & 1974 \\
\hline & & & 0955 & $3,121.2$ & 137.2 & $1,017.4$ & 196.9 & CNT & 1974 \\
\hline \multirow[t]{3}{*}{$51 \mathrm{~T} 29 \mathrm{E}$} & $\mathrm{E}$ & $02-05-91$ & 1621 & 935.3 & 673.6 & 304.9 & 966.7 & MOD & CNT \\
\hline & & & 1627 & 920.0 & 747.8 & 299.9 & $1,073.3$ & 1991 & CNT \\
\hline & & & 1641 & 776.2 & 609.7 & 253.0 & 875.0 & 1987 & CNT \\
\hline \multirow[t]{3}{*}{$51 T 117$} & D & $08-20-91$ & 1040 & $1,139.2$ & $1,239.4$ & 371.4 & $1,778.7$ & 1989 & CNT \\
\hline & & & 1055 & $1,167.7$ & $1,299.7$ & 380.6 & $1,865.3$ & 1989 & CNT \\
\hline & & & 1105 & $1,165.4$ & $1,312.3$ & 379.9 & $1,883.4$ & 1989 & CNT \\
\hline \multirow[t]{3}{*}{$51 \mathrm{~T} 118$} & D & $02-05-91$ & 1408 & 9.248 .4 & $2,933.7$ & $3,014.7$ & 4.210 .3 & CNT & CNT \\
\hline & & & 1415 & $5,103.9$ & $2,621.3$ & 1.663 .7 & $3,762.0$ & CNT & CNT \\
\hline & & & 1428 & $4,300.0$ & $2,094.0$ & $1,401.6$ & $3,005.3$ & CNT & CNT \\
\hline $51 \mathrm{~T} 119$ & D & $08-20-91$ & 1250 & $81,199.2$ & $34,649.6$ & $26,468.2$ & $49,727.1$ & CNT & CNT \\
\hline & & & 1300 & $76,315.2$ & $31,287.0$ & $24,876.2$ & $44,901.2$ & CNT & CNT \\
\hline & & & 1310 & $76,483.1$ & $29,226.1$ & $24,930.9$ & $41,943.6$ & CNT & CNT \\
\hline
\end{tabular}


Table 7. Concentrations of dissolved chlorofluorocarbon-11 and chlorofluorocarbon-12 and recharge dates of ground water in Prince William County, Virginia-Continued

[Detection limits of chlorofluorocarbons are less than 1 picogram per kilogram of solution. Atmospheric partial pressures of chlorofluorocarbons were calculated using a recharge temperature of 9 degrees Celsius at a barometric pressure of 760 millimeters of mercury. CFC,

chlorofluorocarbon; F-11, chlorofluorocarbon-11; F-12, chlorofluorocarbon-12; pg/kg, picogram per kilogram of solution; pptv, parts per trillion volume; CNT, contaminated CFC concentration greater than modern and sample cannot be dated]

\begin{tabular}{|c|c|c|c|c|c|c|c|c|c|}
\hline \multirow{2}{*}{$\begin{array}{c}\text { Local } \\
\text { well } \\
\text { number }\end{array}$} & \multirow[b]{2}{*}{$\begin{array}{c}\text { Hydrogeologic } \\
\text { group }\end{array}$} & \multirow[b]{2}{*}{ Date } & \multirow[b]{2}{*}{ Time } & \multicolumn{2}{|c|}{$\begin{array}{l}\text { Concentration } \\
\text { in solution }\end{array}$} & \multicolumn{2}{|c|}{$\begin{array}{l}\text { Calculated atmospheric } \\
\text { partial pressures }\end{array}$} & \multicolumn{2}{|c|}{$\begin{array}{c}\text { Model CFC } \\
\text { recharge dates }\end{array}$} \\
\hline & & & & $\begin{array}{c}\overline{F-11} \\
(\mathrm{pg} / \mathrm{kg})\end{array}$ & $\begin{array}{c}\text { F-12 } \\
(\mathrm{pg} / \mathrm{kg})\end{array}$ & $\begin{array}{c}\mathrm{F}-11 \\
\text { (pptv) }\end{array}$ & $\begin{array}{c}\text { F-12 } \\
\text { (pptv) }\end{array}$ & $F-11$ & $F-12$ \\
\hline \multirow[t]{3}{*}{$51 \mathrm{~T} 167$} & D & $09-11-91$ & 1500 & 529.0 & 265.9 & 172.4 & 381.5 & 1979 & 1985 \\
\hline & & & 1510 & 531.2 & 282.7 & 173.2 & 405.7 & 1979 & 1986 \\
\hline & & & 1520 & 510.0 & 266.5 & 166.2 & 382.4 & 1979 & 1985 \\
\hline \multirow{3}{*}{$51 \mathrm{T172}$} & $E$ & $08-20-91$ & 1509 & 525.2 & 267.5 & 171.2 & 383.8 & 1979 & 1985 \\
\hline & & & 1525 & 526.6 & 269.1 & 171.6 & 386.3 & 1979 & 1985 \\
\hline & & & 1540 & 516.3 & 263.8 & 168.3 & 378.6 & 1979 & 1985 \\
\hline \multirow{3}{*}{$51 \mathrm{~T} 173$} & $\mathrm{E}$ & $02-05-91$ & 1509 & 472.3 & 337.9 & 153.9 & 484.9 & 1978 & 1990 \\
\hline & & & 1518 & 468.9 & 263.5 & 152.8 & 378.2 & 1978 & 1985 \\
\hline & & & 1528 & 487.1 & 309.5 & 158.8 & 444.2 & 1978 & 1988 \\
\hline \multirow[t]{2}{*}{$51 \mathrm{U} 4 \mathrm{H}$} & B & $08-29-91$ & 1355 & 2.5 & 17.8 & .8 & 25.5 & - & 1958 \\
\hline & & & 1410 & 5.7 & 24.3 & 1.9 & 34.8 & 1953 & 1960 \\
\hline \multirow[t]{4}{*}{51010} & B & $02-04-91$ & 1604 & $22,220.3$ & $2,547.4$ & $7,243.1$ & $3,655.9$ & CNT & CNT \\
\hline & & & 1624 & $23,329.2$ & $2,003.9$ & $7,604.5$ & $2,875.9$ & CNT & CNT \\
\hline & & & 1643 & $25,085.9$ & $2,448.1$ & $8,177.2$ & $3,513.4$ & CNT & CNT \\
\hline & & & 1655 & $23,974.7$ & $2,065.2$ & $7,815.0$ & $2,963.9$ & CNT & CNT \\
\hline \multirow[t]{3}{*}{51011} & B & $09-10-91$ & 1130 & $8,933.3$ & $5,303.7$ & $2,911.9$ & 7.611 .5 & CNT & CNT \\
\hline & & & 1140 & $9,095.1$ & $5,419.1$ & $2,964.7$ & $7,777.1$ & CNT & CNT \\
\hline & & & 1150 & $8,804.7$ & $5,478.1$ & $2,870.0$ & $7,861.8$ & CNT & CNT \\
\hline \multirow[t]{3}{*}{51016} & $\mathrm{~B} 1$ & $09-10-91$ & 0955 & $5,739.3$ & $2,382.1$ & $1,870.8$ & $3,418.6$ & CNT & CNT \\
\hline & & & 1005 & $5,857.9$ & $2,367.0$ & $1,909.5$ & $3,397.0$ & CNT & CNT \\
\hline & & & 1015 & $10,835.2$ & $10,714.2$ & $3,531.9$ & $15,376.4$ & $\mathrm{CNT}$ & CNT \\
\hline \multirow[t]{3}{*}{$51 U 19 D$} & B1 & $08-21-91$ & 1220 & $2,793.7$ & $2,306.0$ & 910.7 & $3,309.5$ & $\mathrm{CNT}$ & CNT \\
\hline & & & 1255 & $2,765.7$ & $2,406.6$ & 901.5 & $3,453.8$ & CNT & CNT \\
\hline & & & 1305 & $2,857.0$ & $2,526.3$ & 931.3 & $3,625.6$ & CNT & CNT \\
\hline \multirow[t]{3}{*}{$51 \mathrm{U} 97 \mathrm{H}$} & $\mathrm{Bl}$ & $02-05-91$ & 0926 & $1,710.7$ & $1,345.7$ & 557.6 & $1,931.3$ & CNT & CNT \\
\hline & & & 0932 & $1,583.9$ & $1,299.6$ & 516.3 & 1.865 .1 & $\mathrm{CNT}$ & CNT \\
\hline & & & 0946 & $1,477.7$ & $1,253.8$ & 481.7 & $1,799.4$ & CNT & CNT \\
\hline \multirow[t]{3}{*}{$51 \mathrm{U} 98 \mathrm{G}$} & B & $09-09-91$ & 1314 & 864.6 & 800.5 & 281.8 & $1,148.9$ & 1990 & CNT \\
\hline & & & 1355 & 838.3 & 778.8 & 273.3 & $1,117.7$ & 1989 & CNT \\
\hline & & & 1405 & 837.6 & 773.2 & 273.0 & $1,109.6$ & 1989 & CNT \\
\hline \multirow[t]{3}{*}{$51 \mathrm{U} 99 \mathrm{G}$} & $\mathrm{Bl}$ & $09-09-91$ & 1120 & 649.6 & 614.5 & 211.7 & 881.9 & 1983 & CNT \\
\hline & & & 1130 & 652.4 & 619.7 & 212.7 & 889.3 & 1983 & CNT \\
\hline & & & 1140 & 640.4 & 614.4 & 208.8 & 881.8 & 1983 & CNT \\
\hline \multirow[t]{3}{*}{$51 \mathrm{U} 100 \mathrm{G}$} & B & 10-10-99 & 1425 & $3,231.0$ & $2,783.5$ & $1,053.2$ & $3,994.7$ & CNT & CNT \\
\hline & & & 1435 & $11,058.6$ & $10,879.4$ & $3,604.7$ & $15,613.5$ & CNT & CNT \\
\hline & & & 1445 & 42.1 & 38.6 & 13.7 & 55.3 & 1961 & 1964 \\
\hline \multirow[t]{2}{*}{$51 \mathrm{U} 101 \mathrm{G}$} & B & $09-10-91$ & 1305 & $5,675.8$ & 636.2 & $1,850.1$ & 913.1 & CNT & CNT \\
\hline & & & 1325 & $5,891.0$ & 657.7 & $1,920.3$ & 944.0 & CNT & CNT \\
\hline \multirow[t]{3}{*}{ 51U102D } & B1 & $09-11-91$ & 1110 & $60,544.6$ & $9,793.6$ & $19,735.5$ & $14,055.2$ & CNT & CNT \\
\hline & & & 1120 & $62,047.2$ & $9,772.4$ & $20,225.3$ & $14,024.8$ & CNT & CNT \\
\hline & & & 1130 & $60,425.6$ & $9,819.3$ & $19,696.7$ & $14,092.1$ & CNT & CNT \\
\hline $51 \mathrm{U} 103 \mathrm{G}$ & $\mathrm{Bl}$ & $02-05-91$ & 1139 & $2,336.2$ & 891.0 & 761.5 & $1,278.8$ & CNT & CNT \\
\hline & & & 1143 & $2,225.8$ & 923.7 & 725.5 & $1,325.7$ & CNT & CNT \\
\hline & & & 1152 & $2,093.1$ & 929.8 & 682.3 & $1,334.5$ & CNT & CNT \\
\hline
\end{tabular}


Table 7. Concentrations of dissolved chlorofluorocarbon-11 and chlorofluorocarbon-12 and recharge dates of ground water in Prince William County, Virginia-Continued

[Detection limits of chlorofluorocarbons are less than 1 picogram per kilogram of solution. Atmospheric partial pressures of chlorofluorocarbons were calculated using a recharge temperature of 9 degrees Celsius at a barometric pressure of 760 millimeters of mercury. CFC,

chlorofluorocarbon; F-11, chlorofluorocarbon-11; F-12, chlorofluorocarbon-12; pg/kg, picogram per kilogram of solution; pptv, parts per trillion volume; $\mathrm{CNT}$, contaminated-CFC concentration greater than modern and sample cannot be dated; MOD, CFC concentration equals modern; $<1945$, model CFC recharge dates earlier than 1945; (e), estimated recharge date]

\begin{tabular}{|c|c|c|c|c|c|c|c|c|c|}
\hline \multirow{2}{*}{$\begin{array}{c}\text { Local } \\
\text { well } \\
\text { number }\end{array}$} & \multirow[b]{2}{*}{$\begin{array}{l}\text { Hydrogeologic } \\
\text { group }\end{array}$} & \multirow[b]{2}{*}{ Date } & \multirow[b]{2}{*}{ Time } & \multicolumn{2}{|c|}{$\begin{array}{c}\text { Concentration } \\
\text { in solution }\end{array}$} & \multicolumn{2}{|c|}{$\begin{array}{l}\text { Calculated atmospheric } \\
\text { partial pressures }\end{array}$} & \multicolumn{2}{|c|}{$\begin{array}{l}\text { Model CFC } \\
\text { recharge dates }\end{array}$} \\
\hline & & & & $\begin{array}{c}\overline{F-11} \\
(\mathrm{pg} / \mathrm{kg})\end{array}$ & $\begin{array}{c}\mathrm{F}-12 \\
(\mathrm{pg} / \mathrm{kg})\end{array}$ & $\begin{array}{c}\text { F-11 } \\
\text { (pptv) }\end{array}$ & $\begin{array}{c}\text { F-12 } \\
\text { (pptv) }\end{array}$ & $\overline{F-11}$ & F-12 \\
\hline \multirow[t]{3}{*}{$51 \mathrm{U} 104 \mathrm{G}$} & $\mathrm{B} 1$ & $02-05-91$ & 1027 & 891.9 & 395.8 & 290.7 & 568.0 & 1990 & MOD \\
\hline & & & 1036 & 869.3 & 429.6 & 283.4 & 616.6 & 1990 & MOD \\
\hline & & & 1104 & 782.0 & 387.7 & 254.9 & 556.5 & 1987 & MOD \\
\hline \multirow[t]{3}{*}{ 51U106D } & $\mathrm{Bl}$ & $09-11-91$ & 0945 & $5,675.3$ & $3,760.8$ & $1,850.0$ & $5,397.3$ & CNT & CNT \\
\hline & & & 0955 & $5,518.0$ & $3,790.9$ & $1,798.7$ & $5,440.5$ & CNT & CNT \\
\hline & & & 1005 & $5,611.2$ & $3,703.1$ & $1,829.1$ & $5,314.5$ & CNT & CNT \\
\hline \multirow[t]{2}{*}{$52 \mathrm{~S} 14$} & $\mathbf{E}$ & $08-13-91$ & 0835 & 13.0 & 95.6 & 4.2 & 137.2 & 1955 & 1971 \\
\hline & & & 0855 & 14.5 & 96.3 & 4.7 & 138.3 & 1955 & 1971 \\
\hline \multirow[t]{2}{*}{$52 \mathrm{~S} 18$} & $\mathrm{E}$ & $08-13-91$ & 1355 & 40.9 & 37.2 & 13.3 & 53.4 & 1961 & 1963 \\
\hline & & & 1400 & 772.7 & 671.1 & 251.9 & 963.2 & CNT & CNT \\
\hline \multirow[t]{3}{*}{$52 S 24$} & $\mathrm{E}$ & $08-19-91$ & 1435 & $1,231.4$ & $1,155.1$ & 401.4 & $1,657.7$ & CNT & CNT \\
\hline & & & 1445 & .0 & .0 & .0 & .0 & $<1945$ & $<1945$ \\
\hline & & & 1515 & .0 & .0 & .0 & .0 & $<1945$ & $<1945$ \\
\hline \multirow[t]{3}{*}{$52 \mathrm{~S} 30$} & E & $08-19-91$ & 1135 & 489.6 & 446.1 & 159.6 & 640.2 & 1978 & CNT \\
\hline & & & 1145 & 421.2 & 455.9 & 137.3 & 654.3 & 1976 & CNT \\
\hline & & & 1215 & 420.5 & 468.1 & 137.1 & 671.8 & 1976 & CNT \\
\hline \multicolumn{10}{|l|}{ 52S 44: } \\
\hline \multirow[t]{3}{*}{ (Artesian flow) } & $\mathrm{F}$ & $08-12-91$ & 1435 & .0 & .0 & .0 & .0 & $<1945$ & $<1945$ \\
\hline & & & 1437 & .0 & .0 & .0 & .0 & $<1945$ & $<1945$ \\
\hline & & & 1445 & .0 & .0 & .0 & .0 & $<1945$ & $<1945$ \\
\hline \multirow{2}{*}{$52 \mathrm{~S} 47$} & F & $09-15-91$ & 1130 & 15.0 & 27.9 & 4.9 & 40.1 & 1956 & 1962 \\
\hline & & & 1140 & $1,053.0$ & $1,331.9$ & 343.2 & $1,911.4$ & CNT & CNT \\
\hline \multirow[t]{3}{*}{$52 \mathrm{~S} 49$} & $\mathbf{F}$ & $08-14-91$ & 1445 & 15.6 & $33,592.8$ & 5.1 & $48,210.3$ & 1956 & CNT \\
\hline & & & 1500 & 12.9 & $27,850.3$ & 4.2 & $39,969.1$ & 1955 & CNT \\
\hline & & & 1515 & 13.2 & $26,120.2$ & 4.3 & $37,486.2$ & 1955 & CNT \\
\hline \multirow[t]{3}{*}{$52 \mathrm{~S} 51$} & $\mathrm{~F}$ & $08-15-91$ & 1515 & 9.2 & 6.3 & 3.0 & 9.1 & 1954 & 1952(e) \\
\hline & & & 1530 & 8.0 & 5.9 & 2.6 & 8.5 & 1953 & 1952(e) \\
\hline & & & 1545 & 173.0 & 6.3 & 56.4 & 9.0 & 1969 & 1952(e) \\
\hline \multirow[t]{3}{*}{$52 \mathrm{~S} 52$} & $\mathrm{~F}$ & $08-16-91$ & 0810 & .0 & .0 & .0 & .0 & $<1945$ & $<1945$ \\
\hline & & & 0830 & .0 & .0 & .0 & .0 & $<1945$ & $<1945$ \\
\hline & & & 0845 & .0 & .0 & .0 & .0 & $<1945$ & $<1945$ \\
\hline \multirow[t]{3}{*}{$52 \mathrm{~T} 66$} & $\mathrm{E}$ & $09-05-91$ & 0920 & .0 & .0 & .0 & .0 & $<1945$ & $<1945$ \\
\hline & & & 0930 & .0 & .0 & .0 & .0 & $<1945$ & $<1945$ \\
\hline & & & 0940 & .0 & .0 & .0 & .0 & $<1945$ & $<1945$ \\
\hline \multirow[t]{3}{*}{$53 \mathrm{~T} 56$} & $\mathrm{E}$ & $08-1491$ & 1115 & 32.0 & 718.1 & 10.4 & $1,030.6$ & 1959 & CNT \\
\hline & & & 1125 & $1,032.1$ & 755.9 & 336.4 & $1,084.9$ & CNT & CNT \\
\hline & & & 1145 & 26.2 & 719.7 & 8.5 & $1,032.9$ & 1958 & CNT \\
\hline
\end{tabular}




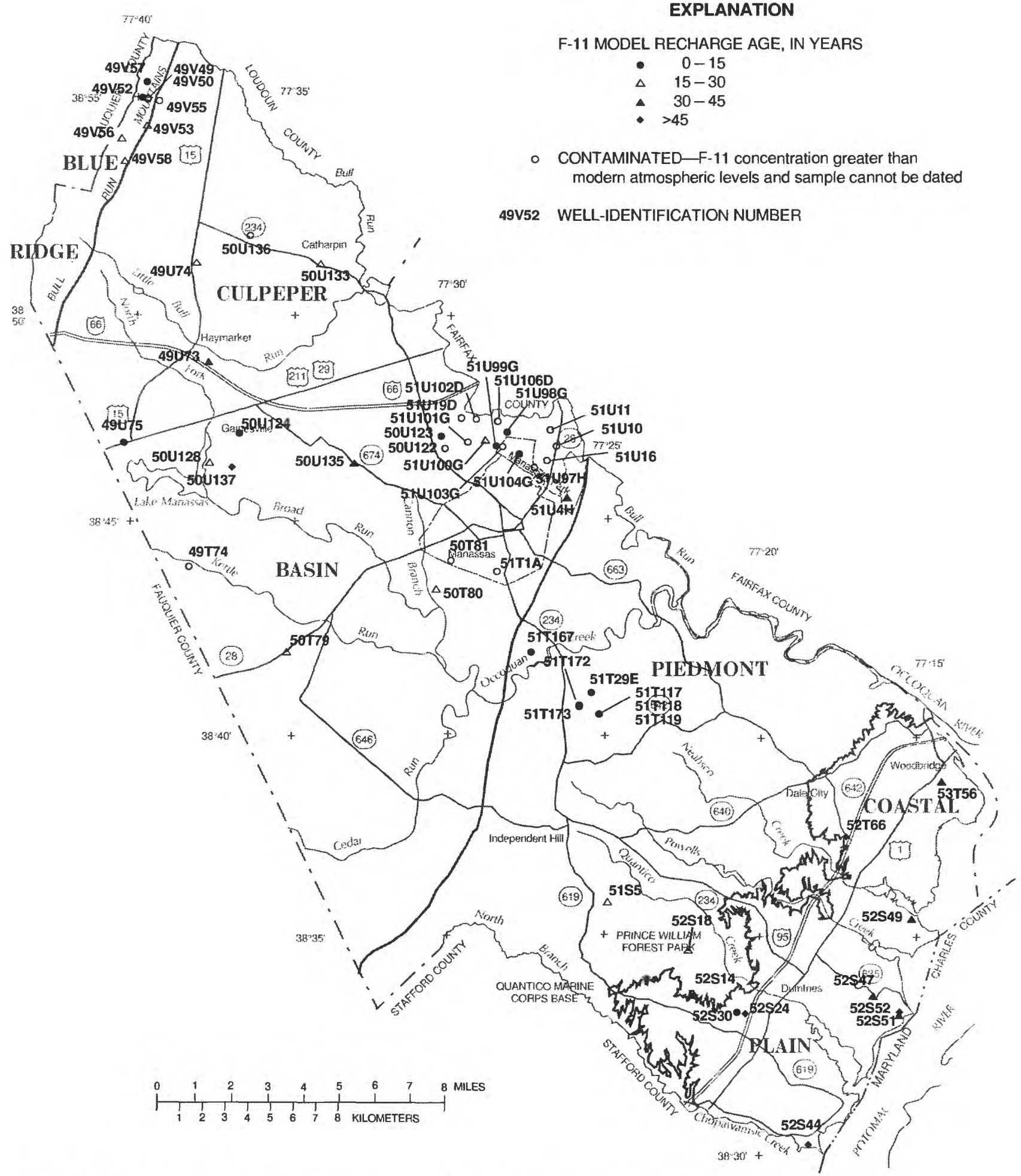

Figure 25. Distribution of chlorofluorocarbon-11 model recharge ages in Prince William County, Virginia. 


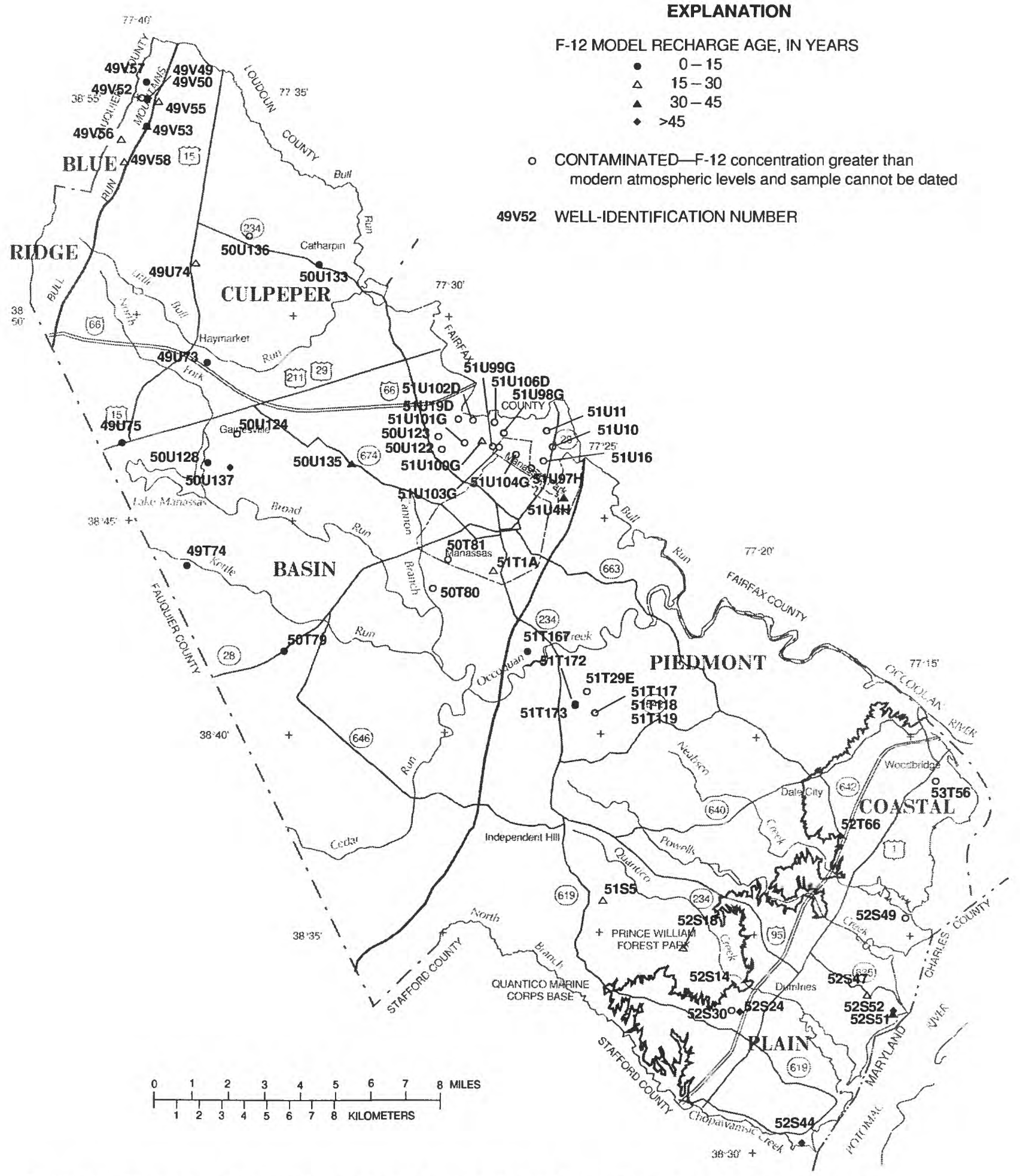

Figure 26. Distribution of chlorofluorocarbon-12 model recharge ages in Prince William County, Virginia. 


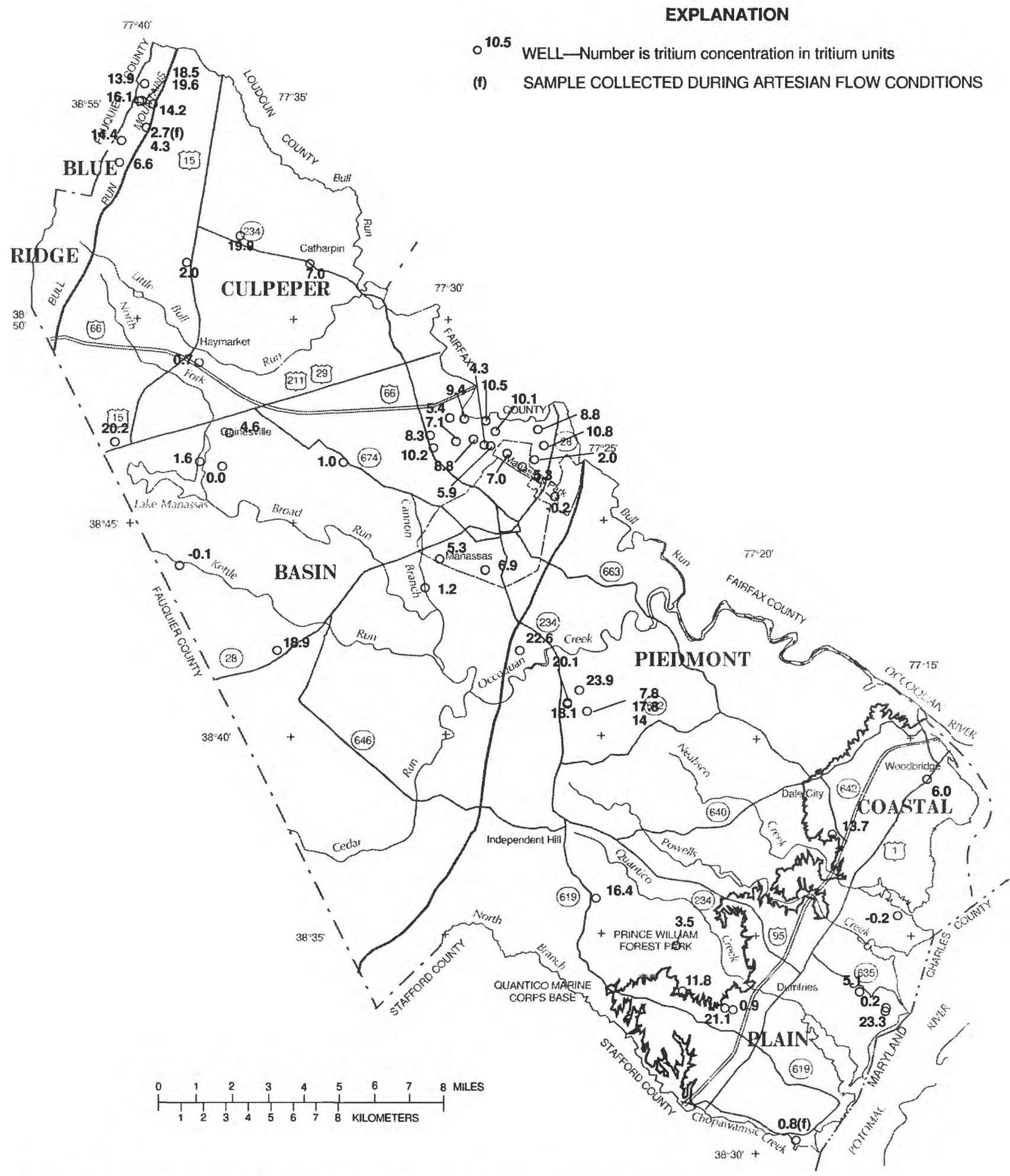

Figure 27. Concentrations of tritium in ground water in Prince William County, Virginia. 
Table 8. Comparison of ground-water-quality analyses, isotopic composition, and recharge ages for well $49 \mathrm{~V} 53$ in the Bull Run Mountain area, northwestern Prince William County, Virginia

[all analyses are for the dissolved constituent unless otherwise noted; ${ }^{\circ} \mathrm{C}$, degrees Celsius; $\mu \mathrm{S} / \mathrm{cm}$, microsiemens per centimeter at $25^{\circ} \mathrm{C} ; \mathrm{mg} / \mathrm{l}$, milligrams per liter; $\mu \mathrm{g} / \mathrm{L}$, micrograms per liter; $\mathrm{pCi} /$ $\mathrm{L}$, picocuries per liter; $\mathrm{CaCO}_{3}$, calcium carbonate; $\mathrm{N}$, nitrogen; $\mathrm{C}$, carbon; $\mathrm{HCO}_{3}$, bicarbonate; <, less than; $A$, ratio of total dissolved solids to specific conductance; $\mathrm{H}-2 / \mathrm{H}-1$ and $\mathrm{O}-18 / \mathrm{O}-16$ ratios are reported relative to Vienna Standard Mean Ocean Water (VSMOW); F-11, chlorofluorocarbon11; F-12, chlorofluorocarbon-12]

\begin{tabular}{|c|c|c|}
\hline \multirow{2}{*}{ Constituent } & \multicolumn{2}{|c|}{ Concentration } \\
\hline & $\begin{array}{l}\text { Artesian flow } \\
\text { sample }\end{array}$ & $\begin{array}{l}\text { Pumped } \\
\text { sample }\end{array}$ \\
\hline Date & $08-27-91$ & $08-27-91$ \\
\hline Time & 1250 & 1415 \\
\hline $\mathrm{pH}$, standard units & 6.8 & 6.6 \\
\hline Specific conductance, $\mu \mathrm{S} / \mathrm{cm}$ & 100 & 95 \\
\hline Dissolved oxygen, $\mathrm{mg} / \mathrm{L}$ & 7.6 & 5.6 \\
\hline Alkalinity, $\mathrm{mg} / \mathrm{L}$, as $\mathrm{CaCO}_{3}$ & 54 & 43 \\
\hline Temperature, ${ }^{\circ} \mathrm{C}$ & 11.0 & 13.5 \\
\hline Hardness, $\mathrm{mg} / \mathrm{L}$, as $\mathrm{CaCO}_{3}$ & 39 & 40 \\
\hline Calcium, mg/L & 8.4 & 9.4 \\
\hline Magnesium, mg/L & 4.3 & 3.9 \\
\hline Sodium, $\mathrm{mg} / \mathrm{L}$ & 4.1 & 3.7 \\
\hline Potassium, $\mathrm{mg} / \mathrm{L}$ & 2.1 & 2.0 \\
\hline Bicarbonate, $\mathrm{mg} / \mathrm{L}$, as $\mathrm{HCO}_{3}$ & 66 & 52 \\
\hline Sulfate, $\mathrm{mg} / \mathrm{L}$ & 1.7 & 2.5 \\
\hline Chloride, $\mathrm{mg} / \mathrm{L}$ & .60 & .70 \\
\hline Fluoride, $\mathrm{mg} / \mathrm{L}$ & .10 & .10 \\
\hline Silica, mg/L & 19 & 15 \\
\hline Total dissolved solids, sum of constituents, $\mathrm{mg} / \mathrm{L}$ & 73 & 63 \\
\hline$A$ & .73 & .66 \\
\hline Nitrite + Nitrate, $\mathrm{mg} / \mathrm{L}$, as $\mathrm{N}$ & $<.050$ & $<.050$ \\
\hline Phosphorus, mg/L & .070 & .070 \\
\hline Aluminum, $\mu \mathrm{g} / \mathrm{L}$ & $<10$ & $<10$ \\
\hline Barium, $\mu \mathrm{g} / \mathrm{L}$ & 15 & 29 \\
\hline 1ron, $\mu \mathrm{g} / \mathrm{L}$ & 25 & 12 \\
\hline Manganese, $\mu \mathrm{g} / \mathrm{L}$ & 3 & 3 \\
\hline Strontium, $\mu \mathrm{g} / \mathrm{L}$ & 52 & 81 \\
\hline Radon-222, pCi/L & 510 & 830 \\
\hline Dissolved organic carbon, $\mathrm{mg} / \mathrm{L}$, as C & .3 & .2 \\
\hline Arsenic, $\mu \mathrm{g} / \mathrm{L}$ & $<1$ & $<1$ \\
\hline Beryllium, $\mu \mathrm{g} / \mathrm{L}$ & $<.5$ & $<.5$ \\
\hline Cadmium, $\mu \mathrm{g} / \mathrm{L}$ & $<1$ & $<1$ \\
\hline Chromium, $\mu \mathrm{g} / \mathrm{L}$ & $<5$ & $<5$ \\
\hline Cobalt, $\mu \mathrm{g} / \mathrm{L}$ & $<3$ & $<3$ \\
\hline Copper, $\mu \mathrm{g} / \mathrm{L}$ & $<10$ & $<10$ \\
\hline Lead, $\mu \mathrm{g} / \mathrm{L}$ & $<10$ & $<10$ \\
\hline Lithium, $\mu \mathrm{g} / \mathrm{L}$ & $<4$ & $<4$ \\
\hline Mercury, $\mu \mathrm{g} / \mathrm{L}$ & $<.1$ & $<.1$ \\
\hline Molybdenum, $\mu \mathrm{g} / \mathrm{L}$ & $<10$ & $<10$ \\
\hline Nickel, $\mu \mathrm{g} / \mathrm{L}$ & $<10$ & $<10$ \\
\hline Silver, $\mu \mathrm{g} / \mathrm{L}$ & $<1$ & $<1$ \\
\hline Vanadium, $\mu \mathrm{g} / \mathrm{L}$ & $<6$ & $<6$ \\
\hline Zinc, $\mu \mathrm{g} / \mathrm{L}$ & 54 & 14 \\
\hline Tritium, total, (tritium units) & 2.7 & 4.3 \\
\hline $\mathrm{H}-2 / \mathrm{H}-1$ stable isotope ratio (per mil) & -47.5 & -48 \\
\hline O-18/O-16 stable isotope ratio (per mil) & -8 & -7.95 \\
\hline F-11 model recharge age & 17 & 27 \\
\hline F-12 model recharge age & 14 & 27 \\
\hline
\end{tabular}




\section{SUMMARY AND CONCLUSIONS}

Prince William County, Va., a rapidly growing suburban area near Washington, D.C., includes parts of four distinct geologic provinces: (1) the Blue Ridge, (2) the Culpeper Basin, (3) the Piedmont, and (4) the Coastal Plain. The hydrogeology is complex and is characterized by ground-water-flow systems in both consolidated rocks and unconsolidated material. A hydrogeologic framework for the county was developed by dividing the rocks in the four geologic provinces into seven hydrogeologic groups on the basis of factors that affect the presence and movement of ground water. The water-bearing potential of the rocks in the Blue Ridge is poor, generally poor to excellent in the rocks of the Culpeper Basin, poor to moderate in the rocks of the Piedmont, and very good to excellent in the unconsolidated material of the Coastal Plain. Generally, the ground-water systems in the county are recharged in elevated areas between stream valleys and discharged to streams and estuaries. The paths and rate of flow of water in consolidated rocks and unconsolidated materials are distinctly different. Water levels generally are highest during April or May and are lowest during September and October Thickness of overburden tends to be thin in the Blue Ridge and the Culpeper Basin and thick in the Piedmont. Declining well yields over time have been observed in some wells, possibly in response to both physical and chemical processes.

The quality of ground water in Prince William County varies across the county. The rocks in the Blue Ridge, the Piedmont, and the Coastal Plain contain minerals that are resistant to weathering, and ground water tends to be acidic with low concentrations of dissolved constituents. The rocks in the Culpeper Basin have an abundance of soluble minerals, and ground water tends to be basic, usually with the highest concentration of dissolved constituents. Dissolved oxygen concentration in ground water tends to be high in the fractured-rock systems, especially in the Blue Ridge. The abundance of the different ionic species in ground water varies between and within the different hydrogeologic groups. For the most part, calcium is the predominant cation and bicarbonate is the predominant anion in ground water of the county. Generally, ground water is soft to moderately hard in the Blue Ridge, the Piedmont, and the Coastal Plain and soft to very hard in the Culpeper Basin. Sulfate concentration in the ground water of the Culpeper Basin is the highest in the county in response to the abundance of gypsum. Nutrient concentration in ground water is low. The only metals that were detected at substantial concentrations in ground water of the county are barium, iron, manganese, strontium, and zinc. Established drinking-water standards were exceeded in water samples from wells for $\mathrm{pH}$ ( 28 percent of the samples), sulfate ( 8 percent), chloride (1 percent), total dissolved solids (12 percent), iron ( 10 percent), manganese (18 percent), zinc ( 1 percent), and radon-222 (93 percent).

The presence and distribution of radon- 222 in ground water are extremely variable and tend to be highest in the rocks of the Piedmont because of the greater abundance of uranium and radium in these rocks than in those in the other areas of Prince William County. Uranium-enriched zones in the black mudstone (lake beds) and sandstone in the Culpeper Basin may explain the high radon- 222 concentration detected in ground water in this area of the county.

Calcium-magnesium bicarbonate is the predominant water type exhibited by the water samples from wells in Prince William County. Ground water in the Culpeper Basin tends to be either a calciummagnesium bicarbonate type or a calcium-magnesium sulfate type at depths greater than $500 \mathrm{ft}$. The presence of gypsum apparently has a strong effect on water types. Ground water in rocks of the Blue Ridge and plutonic rocks of the Piedmont predominantly is calcium-magnesium bicarbonate water. The metamorphic rocks in the Piedmont exhibit three types of water-calcium-magnesium sulfate, calciummagnesium bicarbonate, and sodium bicarbonate. No dominant water type can be described for the Coastal Plain.

The presence of chlorofluorocarbons (CFC's) in ground water in parts of the flow systems in Prince William County indicates that the water is younger than 45 years, especially in the consolidated-rock aquifers. A recharge-water temperature of $9^{\circ} \mathrm{C}$, which was used in the calculations of CFC's partial pressures, was estimated from dissolved gas samples; this indicates that recharge occurs predominantly in the colder months when plants are dormant and evapotranspiration is not a factor. The recharge ages estimated from CFC-11 and CFC-12 concentrations generally were within 5 years of each other, and CFC11 model recharge ages were usually older than those for CFC-12. The samples with the greatest discrepancies between the CFC-11 and CFC-12 ages have low dissolved oxygen concentration, suggesting that 
biodegradation of chlorofluorocarbon-11 is occurring. Precise dating of water from wells in urban settings was not possible, because samples were commonly contaminated with CFC's at concentrations greater than those in the present-day atmosphere.

Samples from high capacity wells tend to have younger recharge ages than those estimated for low yield domestic wells. The deepest water-producing zone that contains CFC's is $840 \mathrm{ft}$ below land surface in a well that is in the Culpeper Basin and also within the high ground-water pumpage area in Manassas and Manassas Park. Stratification of CFC's-model recharge ages is evident in the Coastal Plain. Some of the youngest CFC's-model recharge ages and highest tritium concentration in ground water occur in an area of the Piedmont where thickness of overburden ranges from 60 to $110 \mathrm{ft}$. Evidently, macropores or remnant rock fabric in the saprolite at land surface and shallow depths allows for rapid movement through the unconsolidated part of the ground-water-flow system in this part of the Piedmont. The CFC's-model recharge ages can aid in the evaluation of ground-water resources and in the interpretation of differences detected in water-quality analyses of ground water. Waterresource planners can use recharge ages to effectively design management and protection strategies for their ground-water resources.

\section{SELECTED REFERENCES}

Bates, R.L., and Jackson, J.A., eds., 1987, Glossary of geology (3d ed.): Alexandria, Virginia, American Geological Institute, $788 \mathrm{p}$.

Betz-Converse-Murdoch, Inc., 1982, Groundwater supply study for Prince William County, Virginia: $65 \mathrm{p}$.

Briel, L.I., 1993, Documentation of a multiple-technique computer program for plotting major-ion composition of natural waters: U.S. Geological Survey Open-File Report 93-74, $88 \mathrm{p}$.

Brown, G.A., 1981, Water resources of Prince William Forest Park, Virginia: U.S. Geological Survey Open-File Report 80-964, 2 sheets, scale 1:24,000.

Brown, P.M., Miller, J.A., and Swain, F.M., 1972, Structural and stratigraphic framework, and spatial distribution of the permeability of the Atlantic Coastal Plain: U.S. Geological Survey Professional Paper 796, 79 p.

Busenberg, Eurybiades, and Plummer, L.N., 1991, Chlorofluorocarbons $\left(\mathrm{CCl}_{3} \mathrm{~F}\right.$ and $\left.\mathrm{CC}_{2} \mathrm{~F}_{2}\right)-$ Use as an age dating tool and hydrologic tracers in shallow groundwater systems, in Mallard, G.L., and Aronson, D.A. (eds.), Proceedings, U.S. Geological Survey Toxic
Substances Hydrology Program, technical meeting, Monterey, California, March 11-15, 1991: U.S. Geological Survey Water-Resources Investigations Report 91-4034, p. 542-547.

1992 , Use of chlorofluorocarbons $\left(\mathrm{CCl}_{3} \mathrm{~F}\right.$ and $\mathrm{CCl}_{2} \mathrm{~F}_{2}$ ) as hydrologic tracers and age-dating tools: The alluvium and terrace system of central Oklahoma: Water Resources Research, v. 28, no. 9, p. 2257-2283.

Busenberg, Eurybiades, Weeks, E.P., Plummer, L.N., and Bartholomay, R.C., 1993, Age dating ground water by use of chlorofluorocarbons $\left(\mathrm{CCl}_{3} \mathrm{~F}\right.$ and $\left.\mathrm{CC}_{2} \mathrm{~F}_{2}\right)$ and distribution of chlorofluorocarbons in the unsaturated zone, Snake River Plain aquifer, Idaho National Engineering Laboratory, Idaho: U.S. Geological Survey Water-Resources Investigations Report 93-4054, 47 p.

Cady, R.C., 1933, Preliminary report on ground water in Northern Virginia: Virginia Geological Survey Bulletin 41, 45 p., 1 pl.

1938, Ground-water resources of Northern Virginia: Virginia Geological Survey Bulletin 50, 200 p.

Cecil, L.D., Smith, R.C., III, Reilly, M.A., and Rose, A.W., 1987, Radium-228 and radium-226 in ground water of the Chickies Formation, Southeastern Pennsylvania, in Graves, Barbara, ed., Radon in ground water: Chelsea, Michigan, Lewis Publishers, Inc., p. 437-447.

Cecil, L.D., and Yang, Al, 1987. Guidelines for sampling and analysis for dissolved radon-222 in ground water and surface water: U.S. Geological Survey Office of Water Quality Technical Memorandum no. 88.02.

Cederstrom, D.J., 1945, Geology and ground-water resources of the Coastal Plain in southeastern Virginia: Virginia Geological Survey Bulletin 63, 384 p.

1972, Evaluation of yields of wells in consolidated rocks, Virginia to Maine: U.S. Geological Survey Water-Supply Paper 2021, 38 p.

Chapelle, F.H., 1993, Ground-water microbiology and geochemistry: New York, John Wiley and Sons, Inc., $424 \mathrm{p}$.

Claassen, H.C., 1982, Guidelines and techniques for obtaining water samples that accurately represent the water chemistry of an aquifer: U.S. Geological Survey Open-File Report 82-1024, 49 p.

Comer, C.D., 1976, Prince William County groundwater-Present conditions and prospects: Virginia State Water Control Board, Planning Bulletin 303, 74 p.

Coplen, T.B., 1993, Uses of environmental isotopes, in Alley, W.M., Regional ground-water quality: New York, Van Nostrand Reinhold, p. 227-254.

Cressler, C.W., Thurmond, C.J., and Hester, W.G., 1983, Ground water in the greater Atlanta region: Georgia Department of Natural Resources Environmental Protection Division, Georgia Geologic Survey Information Circular 63, $144 \mathrm{p}$. 
Daniel, C.C., III, 1989, Statistical analysis relating well yield to construction practices and siting of wells in the Piedmont and Blue Ridge Provinces of North Carolina: U.S. Geological Survey Water-Supply Paper 2341-A, p. 27.

Derra, S., 1990, CFCs-No easy solutions: Research and Development, v. 32, p. 54-66.

Drake, A.A., 1989, Metamorphic rocks of the Potomac Terrane in the Potomac Valley of Virginia and Maryland: American Geophysical Union, 28th International Geological Congress, 1989, Field Trip Guidebook T202, $22 \mathrm{p}$.

Drake, A.A., and Lyttle, P.T., 1981, The Accotink Schist, Lake Barcroft Metasandstone, and Popes Head Formation- keys to an understanding of the tectonic evolution of the Northern Virginia Piedmont: U.S. Geological Survey Professional Paper 1205, 16 p.

Drever, J.I., 1988, The geochemistry of natural waters (2d ed.): Englewood Cliffs, N.J., Prentice-Hall, 437 p.

Dunkle, S.A., Plummer, L.N., Busenberg, Eurybiades, Phillips, P.J., Denver, J.M., Hamilton, P.A., Michel, R.L., and Coplen, T.B., 1993, Chlorofluorocarbons $\left(\mathrm{CCl}_{3} \mathrm{~F}\right.$ and $\mathrm{CC}_{2} \mathrm{~F}_{2}$ ) as dating tools and hydrologic tracers in shallow groundwater of the Delmarva Peninsula, Atlantic Coastal Plain, United States: Water Resources Research, v. 29, no. 12, p. 3837-3860.

Durfor, C.N., and Becker, Edith, 1964, Public water supplies of the 100 largest cities in the United States, 1962: U.S. Geological Survey Water-Supply Paper $1812,364 \mathrm{p}$.

Espenshade, G.H., 1970, Geology of the northern part of the Blue Ridge anticlinorium, in Fisher, G.W., and others, eds., Studies of Appalachian Geology, Central and Southern: New York, John Wiley and Sons, Inc., $460 \mathrm{p}$.

1986, Geology of the Marshall quadrangle, Fauquier County, Virginia: U.S. Geological Survey Bulletin $1560,60 \mathrm{p}$.

Fishman, M.J., and Friedman, L.C., 1989, Methods for determination of inorganic substances in water and fluvial sediments ( $3 \mathrm{~d}$ ed.): U.S. Geological Survey Techniques of Water-Resources Investigations, book 5 , chap. A1, 545 p.

Freeze, R.A., and Cherry, J.A., 1979, Groundwater: Englewood Cliffs, N.J., Prentice-Hall, Inc., 604 p.

Friedman, L.C., and Erdmann, D.E., 1982, Quality assurance practices for the chemical and biological analyses of water and fluvial sediments: U.S. Geological Survey Techniques of Water-Resources Investigations, book 5, chap. A6, $181 \mathrm{p}$.

Froelich, A.J., 1985, Map and geotechnical properties of surface materials in the Culpeper basin, Virginia and Maryland: U.S. Geological Survey Miscellaneous Investigations Series Map I-1313-E, scale 1:125,000.
Froelich, A.J., and Leavy, B.D., 1982, Map showing mineral resources of the Culpeper basin, Virginia and Maryland: Availability and planning for future needs: U.S. Geological Survey Miscellaneous Investigations Series Map I-1313-B, scale 1:125,000.

Geraghty and Miller, Inc., 1978, Availability of ground water for public supply in Prince William County, Virginia: Prepared for Wiley and Wilson, Inc., $40 \mathrm{p}$.

Gore, P.J.W., Olsen, P.E., and Schlische, R.W., 1989, Geology of the Culpeper Basin, in Tectonic, depositional, and paleoecological history of Early Mesozoic rift basins, eastern North America: Washington, D.C., American Geophysical Union, 28th International Geological Congress, Field trip guidebook T351, p. 59-68.

Hall, F.R., Boudette, E.L., and Olszewski, W.J., Jr., 1987, Geologic controls and radon occurrence in New England, in Graves, Barbara, ed., Radon in ground water: Chelsea, Michigan, Lewis Publishers, Inc., p. 15-30.

Hamilton, P.A., Shedlock, R.J., and Phillips, P.J., 1991, Water-quality assessment of the Delmarva Peninsula, Delaware, Maryland, and Virginia-Analysis of available ground-water-quality data through 1987: U.S. Geological Survey Water-Supply Paper 2355-B, 65 p.

Hansen, B.P., and Simcox, A.C., 1994, Yields of bedrock wells in Massachusetts: U.S. Geological Survey Water-Resources Investigations Report 93-4115, 43 p.

Heath, R.C., 1980, Basic elements of ground-water hydrology with reference to conditions in North Carolina: U.S. Geological Survey Water Resources Investigations Open-File Report 80-44, 86 p.

1983, Basic ground-water hydrology: U.S. Geological Survey Water-Supply Paper 2220, 84 p.

Hem, J.D., 1960, Restraints on dissolved ferrous iron imposed by bicarbonate redox potential, and $\mathrm{pH}$ : U.S. Geological Survey Water-Supply Paper 1459-E, 55 p.

1985 , Study and interpretation of chemical characteristics of natural waters (3d ed.): U.S. Geological Survey Water-Supply Paper 2254, 263 p.

Hiortdahl, S.N.,in press, Geologic framework, hydrogeology, and ground-water quality of the Potomac Group aquifer system, Northwestern Charles County, Maryland: U.S. Geological Survey Water-Resources Investigations Report 91-4059.

Hopson, C.A., 1964, The crystalline rocks of Howard and Montgomery Counties, in The geology of Howard and Montgomery Counties: Maryland Geological Survey, p. 27-215.

Hurlbut, C.S., and Klein, Cornelis, 1977, Manual of Mineralogy (19th ed.): New York, John Wiley and Sons, $532 \mathrm{p}$.

Johnston, P.M., 1960, Ground-water supplies in shale and sandstone in Fairfax, Loudoun, and Prince William Counties, Virginia: U.S. Geological Survey Circular 424,7 p. 
Jones, B.E., 1987, Quality control manual of the U.S. Geological Survey's National Water Quality Laboratory: U.S. Geological Survey Open-File Report 87-451, $17 \mathrm{p}$.

Kull, T.K., 1983, Water use in Virginia, 1980: Commonwealth of Virginia, State Water Control Board, Basic Data Bulletin 59, 2 p.

Laczniak, R.J., and Zenone, Chester, 1985, Ground-water resources of the Culpeper basin, Virginia and Maryland: U.S. Geological Survey Miscellaneous Investigations Series Map I-1313-F, scale 1:125,000.

Leavy, B.D., 1984, Map showing planar and linear features in the Culpeper basin and vicinity, Virginia and Maryland: U.S. Geological Survey Miscellaneous Investigations Series Map I-1313-G, scale 1:125,000.

Leavy, B.D., Froelich, A.J., and Abram, E.C., 1983, Bedrock map and geotechnical properties of rocks of the Culpeper basin and vicinity, Virginia and Maryland: U.S. Geological Survey Miscellaneous Investigations Series Map I-1313-C, scale 1:125,000.

Leavy, B.D., Grosz, A.E., and Johnson, S.S., 1982, Totalcount aeroradiometric contour map of the Culpeper Basin and vicinity, Virginia: Virginia Division of Mineral Resources Publication 40, scale 1:125,000.

Lee, K.Y., 1979, Triassic-Jurassic geology of the northern part of the Culpeper basin, Virginia: U.S. Geological Survey Open-File Report 79-1557 (parts of 16 quadrangles, scale 1:24,000).

1980, Triassic-Jurassic geology of the southern part of the Culpeper basin and the Barboursville basin, Virginia: U.S. Geological Survey Open-File Report 80468 (parts of 18 quadrangles, scale 1:24,000).

Lee, K.Y., and Froelich, A.J., 1989, Triassic-Jurassic stratigraphy of the Culpeper and Barboursville Basins, Virginia and Maryland: U.S. Geological Survey Professional Paper 1472, 52 p.

Loiselle, Marc, and Evans, David, 1995, Fracture density distributions and well yields in Coastal Maine: Ground Water, v. 33, no. 2, p. 190-196.

Lynch, D.D., Nuckels, E.H., and Zenone, Chester, 1987, Low flow characteristics and chemical quality of streams in the Culpeper geologic basin, Virginia and Maryland: U.S. Geological Survey Miscellaneous Investigations Series Map I-1313-H, scale 1:125,000.

Mann, L.J., 1985, Ground-water-level changes in five areas of the United States, in National water quality summary 1984, U.S. Geological Survey Water-Supply Paper 2275, p. 106-113.

Mazor, Emanuel, 1991, Applied chemical and isotopic groundwater hydrology: New York, Halsted Press, John Wiley and Sons, Inc., 274 p.

Meisler, Harold, and Knobel, L.L., 1994, Documentation of hydrochemical-facies data and ranges of dissolve solids concentrations for the Northern Atlantic Coastal Plain Aquifer System: New Jersey, Delaware,
Maryland, Virginia, and North Carolina: U.S. Geological Survey Open-File Report 94-492, 6 p.

Meng, A.A., III, and Harsh, J.F., 1988, Hydrogeologic framework of the Virginia Coastal Plain: U.S. Geological Survey Professional Paper 1404-C, 82 p.

Mixon, R.B., Berquist, C.R., Jr., Newell, W.L., Johnson, G.H., Powars, D.S., Schindler, J.S., and Rader, E.K., 1989, Geologic map and generalized cross sections of the Coastal Plain and adjacent parts of the Piedmont, Virginia: U.S. Geological Survey Miscellaneous Investigations Series Map I-2033, 2 sheets, scale $1: 250,000$.

Mixon, R.B., and Newell, W.L., 1977, Stafford fault system: Structures documenting Cretaceous and Tertiary deformation along the Fall Line in northeastern Virginia: Geology, v. 5, p. 437-440.

Mixon, R.B., Southwick, D.L., and Reed, J.C., Jr., 1972, Geologic map of the Quantico quadrangle, Prince William and Stafford Counties, Virginia and Charles County, Maryland: U.S. Geological Survey Geologic Quadrangle Map GQ-1044, scale 1:24,000.

Molina, M., and Rowland, F.S., 1974, Stratospheric sink for chlorofluoromethanes: Chlorine atom catalyzed destruction of ozone: Nature, no. 249, p. 810-812.

Morsches, Sara A., and Zenone, Chester, 1981, Index map of flood studies, Culpeper basin, Virginia and Maryland: U.S. Geological Survey Miscellaneous Investigations Series Map I-1313-A, scale 1:125,000.

Mueller, D.K., and Helsel, D.R., 1996, Nutrients in the Nation's waters - Too much of a good thing?: U.S. Geological Survey Circular 1136, 24 p.

Nelms, D.L., and Ahlin, R.J., 1993, Use of chlorofluorocarbons to age date ground water in Prince William County, Virginia [abs.]: Collected Abstracts of the 1993 Virginia Water Resources Conference, Richmond, Virginia, April 12-14, 1993, p. 67.

Nelms, D.L., and Brockman, A.R., 1993, Well-construction, water-level, and ground-water-quality data for Prince William County, Virginia, 1992: U.S. Geological Survey Open-File Report 94-443, 80 p.

Nelms, D.L., and Richardson, D.L., 1990, Geohydrology and the occurrence of volatile organic compounds in ground water, Culpeper Basin of Prince William County, Virginia: U.S. Geological Survey Water Resources Investigations Report 90-4032, $94 \mathrm{p}$.

Nutter, L.J., and Otton, E.G., 1969, Ground-water occurrence in the Maryland Piedmont: Maryland Geological Survey Report of Investigations No. 10, 56 p.

Otton, J.K., Gunderson, L.C.S., and Schumann, R.R., 1993, The geology of radon: U.S. Geological Survey General Interest Publication, $29 \mathrm{p}$. 
Owenby, J.R., and Ezell, D.S., 1992, Monthly station normals of temperature, precipitation, and heating and cooling days 1961-90, Virginia: National Oceanic and Atmospheric Administration, Climatography of the United States no. 81, $20 \mathrm{p}$.

Parker, P.E., 1968, Geologic investigation of the Lincoln and Bluemont quadrangles, Virginia: Virginia Division of Mineral Resources Report of Investigations 14, $23 \mathrm{p}$.

Pavlides, Louis, 1981, The central Virginia volcanic-plutonic belt: an island arc of Cambrian(?) age: U.S. Geological Survey Professional Paper 1231-A, 34 p. 1989, Early Paleozoic composite melange terrane, central Appalachian Piedmont, Virginia and Maryland; its origin and tectonic history: in Geological Society of America Special Paper 228, p. 135- 193.

1990, Geology of part of the Northern Virginia Piedmont: U.S. Geological Survey Open-File Report 90548,1 sheet, scale $1: 100,000$.

Pearson, F.J., Jr., Fisher, D.W., and Plummer, L.N., 1978, Correction of ground-water chemistry and carbon isotopic composition for effects of $\mathrm{CO}_{2}$ outgassing: Geochimica et Cosmochimica Acta, v. 42, p. 17991807.

Posner, Alex, and Zenone, Chester, 1983, Chemical quality of ground water in the Culpeper Basin, Virginia and Maryland: U.S. Geological Survey Miscellaneous Investigations Series Map I-1313-D, 1 sheet, scale 1:125,000.

Powell, J.D., and Abe, J.M., 1985, Availability and quality of ground water in the Piedmont province of Virginia: U.S. Geological Survey Water-Resources Investigations Report 85-4235, 32 p.

Powell, J.D., Wright, W.G., Nelms, D.L., and Ahlin, R.J., 1990, Ground-water contamination and movement at the Defense General Supply Center, Richmond, Virginia: U.S. Geological Survey Water Resources Investigations Report 90-4113, $36 \mathrm{p}$.

Rankin, D.W., Drake, A.A., Jr., Glover, Lynn, III, Goldsmith, R., Hall, L.M., Murray, D.P., Ratcliffe, N.M., Read, J.F., Secor, D.T., Jr., and Stanley, R.S., 1989, Pre-orogenic terranes, in Hatcher, R.D., Jr., Thomas, W.A., and Viele, G.W., eds., The Appalachian-Quachita Orogen in the United States: Boulder, Colorado, Geological Society of America, v. F-2, p. 7-100.

Reilly, T.E., Plummer, L.N., Phillips, P.J., and Busenberg, Eurybiades, 1994, The use of simulation and multiple environmental tracers to quantify groundwater flow in a shallow aquifer: Water Resources Research, v. 30, no. 2, p. 421-433.

Roberts, J.K., 1928, The geology of the Virginia Triassic: Virginia Geological Survey Bulletin 29, 205 p.

Sanford, Samuel, 1913, The underground water resources of the Coastal Plain province of Virginia: Virginia Geological Survey Bulletin 5, $361 \mathrm{p}$.
Scalf, M.R., McNabb, J.F., Dunlap, W.J., Cosby, R.L., and Fryberger, J.S., 1981, Manual of ground-water quality sampling procedures: U.S. Environmental Protection Agency, EPA-600/2-81-160, 93 p.

Schiff, S.L., Aravena, R., Trumbore, S.E., and Dillon, P.J., 1990, Dissolved organic carbon cycling in forested watersheds: A carbon isotope approach: Water Resources Research, v. 26, no. 12, p. 2949-2957.

Seiders, V.M. and Mixon, R.B., 1981, Geologic map of the Occoquan quadrangle and part of the Fort Belvoir Quadrangle, Prince William and Fairfax Counties, Virginia: U.S. Geological Survey Miscellaneous Investigations Series Map I-1175, scale 1:24,000.

Slack, K.V., and Feltz, H.R., 1968, Tree leaf control on low flow water quality in a small stream in Virginia: Environmental Science and Technology, v. 2, p. 126-131.

Sloto, R.A., and Schreffler, C.L., 1994, Hydrogeology and ground-water quality of Northern Bucks County, Pennsylvania: U.S. Geological Survey Water-Resources Investigations Report 94-4109, 85 p.

Smoot, J.P., 1989, Fluvial and lacustrine facies of the Early Mesozoic Culpeper Basin, Virginia and Maryland: Washington, D.C., American Geophysical Union, 28th International Geological Congress, Field trip guidebook T213, $15 \mathrm{p}$.

Southeast Virginia Planning District Commission, 1990, Groundwater protection handbook for Southeastern Virginia, p. 125-128.

Spencer, E.W., 1977, Introduction to the structure of the Earth (2d. ed.): New York, McGraw-Hill, Inc., 640 p.

Stanton, M.R., Wanty, R.B., Lawrence, E.P., and Briggs, P.H., 1996, Dissolved radon and uranium, and groundwater geochemistry in an area near Hylas, Virginia: U.S. Geological Survey Bulletin 2070, 23 p.

Stumm, Werner, and Morgan, J.J., 1981, Aquatic chemistry (2d ed.): New York, John Wiley and Sons, Inc., 780 p.

Swain, L.A., 1993, Hydrogeological characteristics of the bedrock aquifers in the Appalachian Valley and Ridge, Piedmont, and Blue Ridge Physiographic Provinces of the Eastern and Southeastern United States [abs.]: American Association of Petroleum Geologists Bulletin, v77/8, p. 1476.

Szabo, Zoltan, and Zapecza, O.S., 1987, Relation between natural radionuclide activities and chemical constituents in ground water in the Newark Basin, New Jersey, in Graves, Barbara, ed., Radon in ground water: Chelsea, Michigan, Lewis Publishers, Inc., p. 283-308.

Thurman, E.M., 1985, Organic geochemistry of natural waters: Dordrecht, The Netherlands, Martinus Nijhoff/ Dr. W. Junk Publishers, 497 p.

Todd, D.K., 1980, Groundwater hydrology (2d ed.): New York, John Wiley and Sons, Inc., 535 p. 
Trainer, F.W., and Watkins, F.A., Jr., 1975, Geohydrologic reconnaissance of the upper Potomac River basin: U.S. Geological Survey Water-Supply Paper 2035, $68 \mathrm{p}$.

U.S. Environmental Protection Agency, 1995, Drinking water regulations and health advisories: Washington, D.C., Office of Water, $11 \mathrm{p}$.

Wershaw, R.L., Fishman, M.J., Grabbe, R.R., and Lowe, L.E., eds., 1987, Methods for the determination of organic substances in water and fluvial sediments: U.S. Geological Survey Techniques of WaterResources Investigations, book 5, chap. A3, $80 \mathrm{p}$.

Wood, W.W., 1976, Guidelines for collection and field analysis of ground-water samples for selected unstable constituents: U.S. Geological Survey Techniques of Water-Resources Investigations, book 1, chap. D2, $24 \mathrm{p}$.

Zapecza, O.S., and Szabo, Zoltan, 1987, Source and distribution of natural radioactivity in ground water in the Newark Basin, New Jersey, in Graves, Barbara, ed., Radon in ground water: Chelsea, Michigan, Lewis Publishers, Inc., p. 47-68. 